\title{
Ri Koran/Li Xianglan - Visual Reality and Historical Truth
}

\author{
By \\ Mia Fan Ni \\ A thesis submitted to Victoria University of Wellington in \\ fulfilment of the requirements for the degree of Master of \\ Arts
}

School of Languages \& Cultures

Victoria University of Wellington

(2019) 


\section{Abstract}

Li Xianglan, or Ri Koran in Japanese, was a screen sensation and popular culture icon during the Second Sino-Japanese War. Her story of success, however, was overshadowed by her hidden identity as Yamaguchi Yoshiko, a Manchurian-born Japanese promoting Japanese imperialist ideology through the guise of her on-screen Chinese personae. The National Policy Company Manchurian Film Association (Man'ei for short) was established by the Kwantung Army to accelerate the dissemination of Japanese imperialist propaganda. The choice of Ri Koran as the face of Man'ei underlines the significance of her controversial and ambiguous allure, which enabled her to navigate, or "border cross," the complex waters of wartime politics and popular culture during the Sino-Japanese conflict. Through a detailed analysis of one of the Continental Trilogy of films, China Nights (1940), this thesis illustrates how Ri Koran was crafted into a living embodiment of "Hakko Ichiu”, the guiding ideological principle of The Greater East Asia Co-Prosperity Sphere. I investigate the manifestation of "Hakko Ichiu" (Gozoku Kyowa in the Manchurian context) though analysis of particular scenes in the film as well as its use of music, historically known as Continental Melodies. Drawing from existing scholarship by both historians and film scholars, this thesis establishes an important link between these two previously separate scholarly discourses on Ri Koran. 


\section{Contents}

Introduction

Page 4

Ri Koran/Li Xianglan - A War-bred Popular Iconic Star

\section{Chapter One}

The Causes of the Second Sino-Japanese War

The literary foundations of "Hakko Ichiu"

The characteristics of Tanaka Chigaku's Nichirenism

The flourishing of Nichirenism in Manchuria

Manchurian Film Association

Debuting in Wartime Shanghai

Chapter Two

Page 30

China Nights (1940) - A Case Study of Sedating Discontent

Keiran - A stereotype or an unconventional character

Quelling discontent through film

Family - The justification of violence

Marriage - The symbolic completion of "Hakko Ichiu"

Silence - Eloquence without words

\section{Chapter Three}

Continental Melodies - Extension of the Propaganda Narrative

Sugar-coating “Hakko Ichiu”

Ri Koran's “When Will You Return” - Tranforming a Chinese

Patriot's anthem

From Muken to Shanghai, the making of a star

Hattori Ryoichi and his continental melodies

The Resonance of Lyrics

\section{Conclusion}

Ri Koran/Li Xianglan - Icon of Japan's Imperial Unifying Ideology 


\section{Introduction}

\section{Ri Koran/Li Xianglan - A War-bred Popular Iconic Star}

Yamaguchi Yoshiko (山口淑子 1920 - 2014), better known by her Chinese stage name Li Xianglan (李香蘭) in Chinese or Ri Koran in Japanese, was a legend of her era. She was a wartime entertainment star meticulously crafted by the myth-making enterprise of the Manchurian Film Association (満洲映画協会 Manshueiga kyokai or 満映 Man'ei for short). She began her acting career with Man'ei in 1938 at the age of eighteen as a leading actress in the film Honeymoon Express (蜜月快車 Miyue kuaiche). But her first foray into the entertainment industry was as early as age twelve when she performed a Chinese song on the Mukden Radio Station to promote “Japan-Manchuria goodwill” (日満親善 Niman shinzen). This was also the first time she was publicly recognised as "Ri Koran" the Chinese girl. Her intuitive capacity to juggle Japanese and Mandarin, combined with her outstanding acting talent and physical beauty, contributed to her success as Ri Koran first in Manchuria and later in Shanghai.

Ri Koran was promoted and popularised by the Kwantung Army-controlled Man'ei. They gave her the important duty of portraying a convincing image of the ideal Chinese girl in Japanese minds. Aside from making her debut with her Chinese name, which she was given by her Chinese godfather, and ensuring that her language abilities were fully displayed in film, Man'ei also sought to increase the credibility of her Chinese identity by decorating Ri Koran with beautiful cheongsam (旗袍) and custom-made songs. As it turned out, Ri Koran was an investment well-worth these meticulous efforts. Ri Koran eclipsed her mentor and co-actor Hasegawa, a famous Kabuki actor-turned-film-star, who had originally been paired with her as the male lead to help popularise her films. Her iconic image was not only popular among Japanese audiences, but also won the recognition of the Chinese, particularly in Shanghai.

More than a millennium ago, the literary critic Liu Xie (劉劦思 465 AD - 532 AD) penned an 
illuminating passage on the relationship between words, images, and meaning that offers much insight for my deciphering of the Ri Koran story:

或體目文字, 或圖象品物, 纖巧以弄思, 淺察以衒辭, 義欲婉而正, 辭欲隱而 顯。

Words and images delicately and cleverly play on meaning, such that one may misread their purpose at a brief glance. But meaning must be conveyed in enigmatic and profound ways, and words used should be subtle.

Ri Koran ushered in a new pop culture which, although refreshing and delightful from an entertainment perspective, was nevertheless propagandizing. Neither pop culture nor propaganda is particularly noted for subtlety or profundity. However, in the case of Ri Koran, when propaganda is disguised as popular entertainment, and Japaneseness morphs into Chineseness, we must take our cue from Liu Xie and direct our attention to the ways in which "words and images delicately and cleverly play on meaning."

Propaganda films became an instrument of psychological warfare during the Second SinoJapanese War. National Policy films were created to indoctrinate the Japanese public with principles from the Japanese doctrine, “The Cardinal Principles of National Polity” (国体の 本義 Kokutai no Hongi) issued by the Japanese government in 1937, which espoused the “essence” of the Japanese state. ${ }^{2}$ "National Polity" refers to "the central principle that underpinned the mystic and divine authority and sovereignty of the Japanese Emperor". 3 The doctrine has been likened to Hitler’s “Mein Kampf” because it dictated the particular national guidelines of the Japanese people and their duties to the emperor for the pre-war and war years. $^{4}$

Ri Koran was selected and crafted into the main feature of the famous Continental Trilogy which helped imperial Japan promote the political ideology of "Hakko Ichiu" throughout their colonies. Of all the productions starring Ri Koran, this trilogy of films produced from 1939

\footnotetext{
${ }^{1}$ Liu Xie 劉劦思, The Literary Mind and the Carving of Dragons 文心雕龍, Chapter 3 Xie Yin 卷三諧隱.

${ }^{2}$ William Theodore de Bary (ed), Sources of Japanese Tradition: from earliest times to 1600, volume 2 (2 ${ }^{\text {nd }}$ ed). Columbia University Press, 2005, pp. 968 - 975.

3 Satofumi Kawamura, "The National Polity and the Formation of the Modern National Subject in Japan," Japan Forum 2 January 2014, p. 25.

4 国体の本義 Kokutai no Hongi, 日本文学電子図書館 Nippon bungaku denshi toshokan. Retrieved from URL: http://www.j-texts.com/showa/kokutaiah.html., accessed 12 November 2016.
} 
to 1941 has been of greatest interest to many scholars because they are reflections of Japanese wartime national policy. “Hakko Ichiu” (八紘一宇 eight corners of the world under one roof), a slogan used during the Second Sino-Japanese war, promoted the vision of a future in which the different peoples of Asia lived in peace and harmony as part of a Greater East Asia Co-Prosperity Sphere under Japanese leadership. Simultaneously, “Hakko Ichiu” embodied the view of expansion as mandated by Japan's founding myth and therefore was an important principle used to legitimise Japanese imperialism.

Imperial Japan advertised the holiness of war by adopting the "Hakko Ichiu” ideology from ancient Japanese mythology. As part of the process of justifying the war in China, Ri Koran's duty was to preserve the logic of violence while building a satisfactory bridge of goodwill based on “Hakko Ichiu.". Yiman Wang notes that Ri Koran possessed the ability to "felicitously pass into various contexts, meet different expectations, and yet maintain consistent recognisability”, thereby supporting "the intent (of film) to inculcate and entertain the diverse subjectsaudiences." 5

While scholars in film studies such as Wang have highlighted Ri Koran's unique ability to cross cultural borders, ${ }^{6}$ limited consideration has been given to how Ri Koran, through her roles in film and as a cult of personality, functioned in the wider dissemination of wartime national policy. Where scholars like Chikako Nagayama have discussed the concept of "Hakko Ichiu," this has primarily centred on cinematic techniques in National Policy films such as spatial positioning of characters on-screen to create visual metaphors of abstract concepts. ${ }^{7}$ Historians of imperial Japan such as Walter Edwards and Louise Young have demonstrated the importance of "Hakko Ichiu" as an ideology closely related to the battles fought by the Japanese army during the Second Sino-Japanese War. These historians have discussed the application of "Hakko Ichiu" as a nationalistic war slogan and the use of the term in political speeches and official doctrines published by the incumbent government such as the Konoe Cabinet. Walter Edwards, for instance, considers “Hakko Ichiu” to be the origin of Japan’s

\footnotetext{
${ }^{5}$ Yiman Wang, “Affective Politics and the Legend of Yamaguchi Yoshiko/Li Xianglan” in Katsuhiko Endo, Cody Poulton, Richard King (eds), Sino-Japanese Transculturation: Late Nineteenth Century to the End of The Pacific War, Rowman \& Littlefield, 2011, p. 147.

${ }^{6}$ Yiman Wang, “Screening Asia: Passing, performative translation, and recognition,” Positions 15(2) 2007, pp. 319-343. Here Wang describes Ri Koran's characteristics as "border-crossing mobility and variable identity". ${ }^{7}$ Chikako Nagayama, Fantasy of Empire: Ri Koran, subject positioning, and the cinematic construction of space, $\mathrm{PhD}$ thesis, University of Toronto, 2009, p. 85.
} 
expansionist view and the source of its alleged moral superiority over other nations. ${ }^{8}$

In this thesis, I identify a disconnect between the two predominant approaches to the study of Ri Koran and her films - one from film studies and the other from history - and I seek to demonstrate that the most fruitful understanding of Ri Koran's life and work lies in a combination or a dialogue between the two approaches. This thesis illustrates how Ri Koran was crafted into a living embodiment of "Hakko Ichiu," the guiding ideological principle of The Greater East Asia Co-Prosperity Sphere, through a complex dynamic of cultural, commercial, and political forces.

I start with an extended Background section, in which I outline in detail the intricate historical and cultural links behind the ideology of “Hakko Ichiu,” Man'ei, and Ri Koran's film career, against the backdrop of the Second Sino-Japanese War. In Chapter One, I analyse in detail one of the Continental Trilogy films, China Nights (1940), to investigate the manifestation of "Hakko Ichiu" in particular scenes and highlight the contrasts between the proclamation of harmony in imperialist ideology and the brutality of wartime reality. In Chapter Two, I demonstrate how Continental Melodies, a wartime genre that served as musical accompaniment to National Policy films, extended the reach of their messages from image to sound. Apart from linking this genre of music and its evolution to the cultural milieu of cosmopolitan Shanghai, I use “Soshu Yakyoku” (蘇州夜曲), a popular Continental Melody composed by Hattori Ryoichi and performed by Ri Koran in China Nights, as a case study of how Japanese imperialist ideology and Shanghai's cosmopolitanism both resonate within this genre of music.

\footnotetext{
${ }^{8}$ Walter Edwards, "Forging a Tradition for a Holy War: The 'Hakko Ichiu' Tower in Miyazaki and Japanese Wartime Ideology,” Journal of Japanese Studies 29:2, 2003, pp. 301-305.
} 


\section{Chapter One}

\section{The Causes of the Second Sino-Japanese War}

\section{The Literary Foundations of "Hakko Ichiu”}

In October 1937, the Japanese government launched an extensive propaganda campaign known as the National Spiritual Mobilisation Movement (国民精神総動員運動 Kokumin seishin sodoin undo) to coincide with the commencement of the Second Sino-Japanese war earlier in July of the same year. This propaganda campaign was aimed at rallying public support for the war as quickly as possible.

The term “Hakko Ichiu” (八紘一宇 eight corners of the world under one roof) was employed as one of the key campaign slogans, reifying its significance as a core ideological concept driving government policy. This four-character term was widely displayed and quoted alongside other political slogans such as “one hundred beating hearts beating as one” (一億一 心 Ichioku isshin). ${ }^{9}$ As a catchphrase, “Hakko Ichiu” formed part of the government's strategy of using education, culture, entertainment, and the mass media to "raise morale and to consolidate public support for the government” and its continued military pursuits in China. ${ }^{10}$ "Hakko Ichiu” even found its way into the lyrics of a Japanese war song entitled " Patriotic March” (愛國行進曲 Aikyoku koshinkyoku) produced in 1937 to coincide with the National Spiritual Mobilisation Movement. ${ }^{11}$

Prime Minster Fumimaro Konoe’s political doctrine “New Order” (新体制 Shintaisei) became

\footnotetext{
9 Japan's Road to War: A Brief Synopsis. Retrieved from: http://www.willamette.edu/ rloftus/rdtowar.html.

${ }^{10}$ Ben-ami Shillony, Politics and Culture in Wartime Japan, Clarendon Press, 1991, p 5.

${ }^{11}$ Verse two of the song reads:

Tate! Ikkei no okimi wo/ Hikari to towa ni itadakite/ Shinmin warera mina tomoni/ Miitsu ni sowan daishimei/ Yuke, hakko wo ie to nashi/ Shikai no hito wo michibikite/ Tadashiki heiwa uchitaten/ Riso wa hana to saki kaoru/ hakko wo ie to nashi

Retrieved from URL: http://gunka.sakura.ne.jp/en/aikokukoshinkyoku.htm., accessed 1 August 2017.
} 
official state policy in November 1938. ${ }^{12}$ The doctrine consolidated his ideas on the political and economic reconstruction of the nation, which involved not merely the creation of a new domestic order, but also the spread of Japan's influence abroad in the name of achieving lasting international peace.

What Japan seeks is the establishment of a new order which will insure the permanent stability of East Asia. In this lies the ultimate purpose of our present military campaign. $^{13}$

This announcement came as no surprise. As early as March 1937 with the publication of a 156-page booklet, Cardinal Principles of the National Entity of Japan (国体の本義 Kokutai no Hongi), the government sought to create a national identity by producing a set of guidelines that defined what it meant to be "Japanese" and "to articulate an official ideology for a nation on the brink of war". ${ }^{14}$ The Cardinal Principles discussed the Shinto creation mythology of the goddess Amaterasu (天照) and stressed the application of the lofty spirit of “Hakko Ichiu” as found in the mythology of Emperor Jinmu (神武天皇). ${ }^{15}$

The phrase "Hakko Ichiu" was first officially used and circulated as a guiding principle of state policy on 1 August 1940 when the Cabinet of Prime Minister Fumimaro Konoe made the following announcement to explain why Japan was compelled to invade China:

The basic aim of Japan's national policy lies in the firm establishment of world peace in accordance with the lofty spirit of "Hakko Ichiu" (the eight corners of the world under one roof), in which the country was founded, and in the construction, as the first step, of a new order in Greater East Asia, having for its foundation the solidarity of Japan, Manchukuo and China. ${ }^{16}$

In the concept of "Hakko Ichiu", the "roof" represented Japan or the singular "heaven of

\footnotetext{
12 Sharon Orbaugh, Propaganda Performed: Kamishibai in Japan's Fifteen Year War, BRILL, 2014, p. 89.

${ }^{13}$ Roger Brown, “Konoe Cabinet’s ‘Declaration of a New Order in East Asia', 1938” in Sven Saaler and Christopher W.A.Szpilman (eds), Pan-Asianism: A Documentary History, 1920-Present, Rowman \& Littlefield Publishers, 2011, p. 170.

${ }^{14}$ William Theodore de Bary (ed), Sources of Japanese Tradition: from earliest times to 1600, volume 2 ( $2^{\text {nd }}$ ed). Columbia University Press, 2005, pp. 968-969 and 975.

15 John Owen Gauntlet (trans.), Kokutai no Hongi: Cardinal Principles of the National Entity of Japan, Cambridge, Mass: Harvard University Press, 1949.

${ }^{16}$ Japanese Government Announcement, August 1, 1940, Contemporary Japan, vol IX, no 9, September 1940, p. 1223.
} 
benevolent imperial rule" ${ }^{17}$ and the "eight corners" were the rest of Asia. The phrase could be interpreted metaphorically as consolidating Asia under one authority, that of Japanese imperial rule. The proclaimed long-term political goal was to achieve harmony through unity, and lasting peace through eradicating the common Communist enemy. All this was envisioned with the purpose of extending regional integration in East Asia under the leadership of the Japanese empire. ${ }^{18}$ Therefore, the concept of bringing "eight corners of the world under one roof" became symbolic of the Konoe government's political ambitions.

An Imperial Rescript produced in September 1940 after the signing of the Tripartite Pact among the Axis powers of Germany, Italy, and Japan, made reference to “Hakko Ichiu” again:

The teaching of the eight corners of the world under one roof is the teaching of our imperial ancestors...We sincerely hope to bring about a cessation of hostilities and a restoration of peace. ${ }^{19}$

The phrase and concept of "Hakko Ichiu" derives from an archaic kingship myth of the Nara period used to legitimize the rule of the imperial household. ${ }^{20}$ The significance and interpretive malleability of "Hakko Ichiu" is evidenced by how it became a fundamental guiding principle of Japan's domestic and foreign policy during the war years of the 1930s and 1940s.

Prime Minister Fumimaro Konoe (in office June 1937 to January 1939, July 1940 to October 1941) was known for his royal title as Prince Konoe. Born into the Fujiwara clan, an aristocratic family of regents that claimed descent from a Shinto deity, Konoe was already well connected within the higher echelons of Japan's governing circles when he assumed the position of Prime Minister. It was a volatile time to be in politics because talk of creating a new order for Japan was rife among the political elite. ${ }^{21}$ Konoe too was sympathetic "with the objectives of renovating the domestic political order and enhancing Japan’s position in East Asia”. ${ }^{22} \mathrm{He}$

\footnotetext{
${ }^{17}$ Miwa Kimitada, “Pan-Asianism in modern Japan - Nationalism, regionalism and universalism” in Sven Saaler, J. Victor Koschmann (eds), Pan-Asianism in Modern Japanese History - Colonialism, Regionalism and Borders, Routledge, 2007, p. 22.

${ }^{18}$ Roger Brown, “The Konoe Cabinet’s ‘Declaration of a New Order in East Asia’, 1938” in Sven Saaler and Christopher W.A.Szpilman (eds), Pan-Asianism: A Documentary History, 1920 - Present, Roman \& Littlefield Publishers, 2011, p. 168.

${ }^{19}$ Francis Pike, Hirohito's War: The Pacific War, 1941 - 1945. Bloomsbury Publishing, 2016, p. 55.

${ }^{20}$ Waida Manabu, “Sacred Kingship in Early Japan: A Historical Introduction”, History of Religions 15(4), (May 1976), p. 323. See also W. G. Aston (trans.), Nihongi. 2 vols, London, 1956.

${ }^{21}$ Roger Brown, p. 167.

22 Ibid.
} 
was the first Japanese statesman to employ the important concept of "Hakko Ichiu" in official policy as justification for Japan's Pan-Asian imperialistic expansion in the 1930s and 1940s. ${ }^{23}$

Prime Minister Konoe did not stop promoting this idea. He took a step forward by visualising it. In 1940, Japan celebrated the $2,600^{\text {th }}$ anniversary of the founding of its imperial dynasty. In the city of Miyazaki, a stone tower named the Hakko Ichiu Tower (八紘之基柱 Ametsuchi no motohashira), standing almost 37 metres tall, was erected to commemorate the ascension of the legendary Emperor Jinmu to the imperial throne on this day. The words "Hakko Ichiu” were carved into the front face of the tower. ${ }^{24}$ The modern day prefecture of Miyazaki was believed to be the place where the goddess Amaterasu's descendants, including Emperor Jinmu, resided until the latter decided to journey east to subdue the central province of Yamato and secure the Japanese homeland for the rule of Amaterasu's line. ${ }^{25}$ Right up to the completion of the tower, progress on the construction was covered well in the Osaka newspaper, which described the tower as a "symbol of the nation's fortunes and of the spirit of the Japanese". ${ }^{26}$ In an effort to demonstrate the spread of "imperial Virtue", a plaque was affixed to the tower proclaiming that the Japanese empire extended "from the banks of the Amur River in the north across the Mongolian wilderness in the west, and linking North, Central, and South China, stretches to the distant South Seas”. ${ }^{27}$

\footnotetext{
${ }^{23}$ Bob T Wakabayashi (ed), Modern Japanese Thought. Cambridge University Press, 1998, p. 17. See also Eizawa Koji, Daito-A kyoeiken no shiso, Tokyo: Kodansha, 1995, pp. 102 - 107.

${ }^{24}$ Walter Edwards, “Forging Tradition for a Holy War: The 'Hakko Ichiu' Tower in Miyazaki and Japanese wartime ideology The Journal of Japanese Studies 29(2) (Summer 2003), p. 289.

${ }^{25}$ Ibid, pp. 290-291.

${ }^{26}$ Ibid, p. 296.

27 “Heiwa no To" no Shijitsu wo Kangaeru Kai, Ishi no Shogen, Miyazaki-ken Higashi Morokata-gun Takaoka -cho: Honda Kikaku, 1985, p. 102.
} 


\section{This content is}

unavailable.

Please consult the print version for access.

Figure 1 Hakko Ichiu Tower in Miyazaki.

Source: Walter Edwards, "Forging Tradition for a Holy War: The 'Hakko Ichiu' Tower in Miyazaki and Japanese wartime ideology”.

The iconic nature of the Hakko Ichiu Tower was evidenced by its appearance on the 10 yen banknote in circulation between 1944 and 1953. For "first-day cover" commemorative stamps of the 2,600"th anniversary, 10 yen stamps depicted the words "Hakko Ichiu". Visual representations of "Hakko Ichiu" were advertised throughout Japan, making the hype of outward expansionism powerfully present in the everyday lives of Japanese citizens.

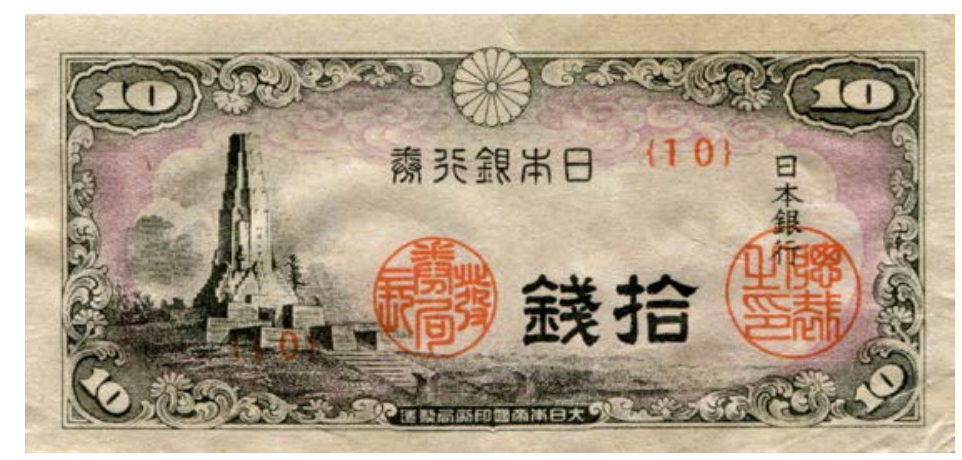

Figure 2: A 10 yen bank note. 
This content is unavailable.

Please consult the print version for access.

Figure 3: The first-day cover of stamps issued to commemorate the $2600^{\text {th }}$ anniversary of Japan's creation.

Source: The International Society For Japanese Philately, Stephen Dowd Exhibition, "Sun Rise, Sun Set - The Rise and Fall of Japan's Colonial Power 1931-1951. Retrieved from URL:

http://www.isjp.org/static/files/pdfs/Stephen\%20Dowd\%20Exhibit-

Part\%201.pdf.http://www.isjp.org/static/files/pdfs/Stephen Dowd Exhibit-Part 1.pdf

The reference to "Hakko Ichiu" occurs in The Chronicles of Japan (日本書紀 Nihon Shoki), one of the earliest classical Japanese history books from the Nara period. This book was completed under the supervision of the prince Toneri (舎人親王, 676 AD-735 AD). Its principal purpose was to consolidate and assert the ruling legitimacy of the imperial family of Japan by claiming direct lineage from the ancient Shinto goddess, Amaterasu. This literary collection contained a series of creation myths aptly described by scholars as "myths of kingship" ${ }^{28}$ In one myth, Emperor Jinmu, a descendent of Amaterasu, led an expedition east from Hyuga (modern-day Miyazaki) to subdue the central province of Yamato, "thereby securing the Japanese homeland for rule by Amaterasu's line in perpetuity”. ${ }^{29}$ Emperor Jinmu built his palace at Kashihara, intending to use this place as a capital "from which to unite the whole realm, and place the eight corners under (a single) roof" ${ }^{30}$ The unification of the "eight

\footnotetext{
${ }^{28}$ Kazuo Matsumura, Alone among women: A Comparative Mythic Analysis of the Development of Amaterasu Theology, Institute for Japanese Culture and Classics, Kokugakuin University, 2000. Retrieved from URL: http://www2.kokugakuin.ac.jp/ijcc/wp/cpjr/kami/matsumura.html. Accessed in August 2016.

${ }^{29}$ Walter Edwards, "Forging Tradition for a Holy War: The 'Hakko Ichiu' Tower in Miyazaki and Japanese wartime ideology”, The Journal of Japanese Studies 29(2) (Summer 2003), pp. 290-291.

${ }^{30}$ Ibid. Translations of this passage in the Nihongi vary. The translation used here draws from John Owen Gauntlet's 1949 translation of Kokutai no Hongi: Cardinal Principles of the National Entity of Japan. The original passage in classical Japanese reads: 兼六合以開都、掩八紘而為宇 (with hiragana translations: 然りし て後に、六合（くにのうち）を兼ねて都を開き、八紘（あめのした）を掩（おほ）ひて宇（いへ）にせむ
} 
corners” of the world under “one roof” can be read as an assertion of Emperor Jinmu's authority and by virtue of association, the authority of the imperial household from which he was descended. His proclamation is encapsulated in the phrase:

\section{八紘を掩うて宇と為さん \\ Hakko wo oute ie to nasan}

This phrase translates roughly to "I shall cover the eight directions and make them my abode." The phrase would later be adapted into a slogan and its meaning extended to encompass the concept that Japan was divinely ordained to expand and conquer until she had achieved unification of the world in the name of peace.

"Hakko Ichiu” is a composite of two terms from Emperor Jinmu’s original statement: "Hakko" (八紘, translated as “eight corners”) and “Ichiu” (一宇, as modified from the term 為宇, and translated as “one universe” or "one roof”). The term "Hakko" can be written in Chinese as 八 紘 it is a term can be located within an ancient Chinese collection of literary texts known as Huai Nan Zi or Huai Nan Hong Lie (淮南子/淮南鸿烈), which precedes The Chronicles of Japan. Huai Nan $\mathrm{Zi}$ was a compendium of essays drawn from a series of scholarly debates (approximately 139 BC) in the court of Liu An, the king of Huai Nan from the Western Han Dynasty. These essays covered a broad range of subjects from mythology, history, geography, and philosophy to science, metaphysics, and politics ${ }^{31}$ and were based on an amalgamation of Daoist (道), Confucianist (儒), and Legalist (法) teachings.

The extract from Huai Nan Zi relevant to the Japanese slogan "Hakko Ichiu” can be found in a chapter known as “Di Xing Xun” (地形訓) where the term “Hakko” made its first appearance. ${ }^{32}$ “Di Xing Xun” focused on analysing the relationship between geography and strategies of war, making it essentially a military text.

In “Di Xing Xun”, the Chinese character “紘” (hong) can be translated as "expansiveness”33

\footnotetext{
こと、亦可（ょ）からずや).

${ }^{31}$ Zhang Shuang Di 張雙棣 Huai Nan Zi Xiao Shi (Zeng ding ben) 淮南子校釋(增訂本). Beijing daxue chubanshe, 2013.

${ }^{32}$ In “Di Xing Xun” , the term “八紘” appears in the sentence: 九州外有八澤、方千里。八澤之外、有八 紘、亦方千里、蓋八索也。一六合而光宅者、並有天下而一家也.

${ }^{33}$ Definition retrieved from Zhong Guo Zhe Xue Shu Dian Zi Hua Ji Hua 中國哲學書電子化計劃.
} 
while “八紘” (ba hong) can be translated as the “coverage of great distances” and has been used to describe the expanse of the Nine Provinces of ancient China (九州). ${ }^{34}$ The Nine Provinces were a collective symbolic reference for the territories that formed ancient China during the Xia, Shang, and Zhou Dynasties ${ }^{35}$ and subsequently came to refer to specific regions of governance during the Han Dynasty. ${ }^{36}$

\section{The Characteristics of Tanaka Chigaku's Nichirenism}

The person who first cobbled together the four-character lexeme of "Hakko Ichiu” was Tanaka Chigaku (田中知学), leader of the Nichirenism (日蓮主義) sect which was an offshoot of Nichiren Buddhism (法華宗). He had extracted the words from The Chronicles of Japan and published the catchphrase in an article written for the Nichirenism-specific newspaper Kokuchu Shinbun (国柱新聞). The article, published on 11 March 1913, was titled, “The Creation of the Nation by Emperor Jinmu” (神武天皇の建 Jinmu tennou no ken). ${ }^{37}$ In this crucial piece of writing, Tanaka changed the original words recorded in The Chronicles of Japan relating Emperor Jinmu's “Edict on the Construction of the Kashihara Palace” where the Emperor was to accede to the throne. The original statement of “Hakko wo oute ie to nasan” (八紘を掩う て宇と為さん ) ${ }^{38}$ would be replaced by a compact four-character idiomatic compound "Hakko Ichiu” (八紘一宇). Effectively, Tanaka had created a “yojijukugo” (四字熟語) ${ }^{39}$ which is a Japanese lexeme consisting of four kanji (Chinese characters). This clever literary innovation fully capitalised on the ability of lexemes to embody a wealth of meaning. In particular, the lexeme "Hakko Ichiu" enabled its mythological reference to be easily remembered and the

\footnotetext{
${ }^{34}$ He Zhi Hua 何志華 Tang Song Lei Shu 唐宋類書徵引《淮南子》資料彙編. Chinese University Press, 2005, p. 57. In “Di Xing Xun”, the relevant phrase reads: 九州之外乃有八殥, 八殥之外而有八紘 where 九州 is a geospatial conceptualisation of the territories of China as the epicentre of the universe, while 八殥 and 八 紘 are measures of great distance. The latter, being greater than the former, can be defined as the far-flung reaches of the universe.

${ }^{35}$ In the ancient text Shang Shu 尚书， there are records of China being divided into the Nine Provinces:

天下分為九州, 分別為冀州、充州、青州、徐州、揚州、荊州、梁州、雍州、豫州.

${ }^{36}$ The division of land into separate administrative regions or “州” appears to have been done by Emperor Hanwudi in Han Shu - Wudi Ji: “初置刺史, 部十三州”.

${ }^{37}$ Nitta Hitoshi 新田均, “Arahito gami” “Kokka shindo” to iu gensou - “zetaikami” wo yobidashita no dareka

「現人神」「国家神道」という幻想一「絶対神」を呼び出したのは誰か,Jinja shinposha, 2014/15, pp. 49-51.

${ }^{38}$ Nihon shoki maki daisan 日本書紀巻第三（神武天皇即位前紀已未年三月丁卯条の「令」）.

${ }^{39}$ Nitta Hitoshi 新田均, pp. 49-51.
} 
underlying imperialist concept of expansionism to be easily employed within writing and speech. In his writing, Tanaka interpreted "Hakko Ichiu" as the "unification of the world through the moral authority of the Emperor” (天皇による世界の道義的統一). ${ }^{40} \mathrm{He}$ saw the place and value of the Nichirenism sect as a fundamental pillar of support for the state and its expansionist goals by providing the moral persuasion "to bestow legitimacy on the postulation” that the world revolved around Japan and its Emperor. ${ }^{41}$ Nitta Hitoshi (新田均), a Shinto historian, considers Tanaka to be the principal advocate of the idea that under "Hakko Ichiu” ideology, Japan is the centre of the universe with power and control over the rest of the world. $^{42}$

This brings us to the importance of Nichirenism to the application of "Hakko Ichiu" ideology during the Second Sino-Japanese War.

As an offshoot of Nichiren Buddhism, Nichirenism shared the former's interest in religion's involvement in political affairs, and the radicalism of its ideas on this relationship. Saint Nichiren (1222 - 1282), who is credited with the origination of the Nichiren Buddhist tradition, wrote an important treatise entitled "On Establishing the Correct Teaching for the Peace of the Land” (立正安国論 Rissho Ankoku Ron). In this admonitory treatise, he emphasised the role of religion in the affairs of the state. ${ }^{43}$ The radicalism of Saint Nichiren is most glaring in his bold deviation from “old” Buddhism, which affirmed the authority of the Japanese Emperor by virtue of his divine lineage. In Saint Nichiren's thought, Buddhist law took precedence over earthly political authority and the Emperor stood equal to every ordinary man before the Transcendent Being Sakyamuni Buddha, to the extent that the seat of Emperor itself could be transferred to someone else. ${ }^{44}$ For the incumbent in the seat of political power, this was clearly a dangerous proposition and one that needed to be suitably restrained. Hence, many of Saint Nichiren's followers were subject to persecution such that only groups that found ways to suitably reconcile themselves with the incumbent political authority were allowed to continue

\footnotetext{
${ }^{40}$ Nitta Hitoshi 新田均, 第三章「八紘一宇」の提唱者 - 田中智学 Chapter 3 “Hakko Ichiu” no Teishosha - Tanaka Chigaku, "Arahito gami" "Kokka shindo" to iu gensou - "zetaikami” wo yobidashita no dareka「現人 神」「国家神道」という幻想一「絶対神」を呼び出したのは誰か, Jinja shinposha, 2014/15, pp. 49-51.

${ }^{41}$ Hirou Sata, "Nichiren Thought in Modern Japan: Two Perspectives”, The Journal of Oriental Studies 10, (2000), p. 50.

${ }^{42}$ Ibid.

${ }^{43}$ Sokka Gakkai, Nichiren Buddhism Library, "On Establishing the Correct Teaching for the Peace of the Land." Retrieved from URL: http://www.nichirenlibrary.org/en/wnd-1/Content/2., accessed 12 November 2016.

${ }^{44}$ Hirou Sato and Ruben Habito, “Nichiren's View of Nation and Religion,” Japanese Journal of Religious Studies 26(3/4) (Fall 1999), p. 317.
} 
to exist as religious bodies.

However, Nichiren Buddhism and Nichirenism differ in various important ways, such as their proposed methods for achieving ultimate peace and stability. According to the canonical Nichiren Buddhist text, “On Establishing the Correct Teaching for the Peace of the Land”, Saint Nichiren described three disasters and seven calamities (三災七難) detrimental to the peace and stability of a state, one of which was the crisis of war (兵革). ${ }^{45}$ He advocated that the Buddhists should pray for national peace before they think of how they will survive. ${ }^{46}$ This verse was interpreted by Hojo Tokiyori (北条時頼), the fifth and incumbent regent of the Kamakura Shogunate (鎌倉幕府), to mean that the first step to lasting peace is to pray for the stability of the state, to put an end to disasters, and after that, to seek the correct education (ま ずは国家の安泰を祈って ...). ${ }^{47}$

This rejection of war and focus on peace differs from Tanaka's Nichirenism which is characterised by a strong militaristic element. For Tanaka, war is a means to an end. Therefore he read into Nichiren's teachings an approval of the use of force, as demonstrated in his statement, "Nichiren is the general of the army that will unite the world. Japan is his headquarters. The people are his troops." 48 He advocated reform through the formation of a Nichiren organization with Buddhism as a militant, revolutionary force and preached aggression as "the way of the world". ${ }^{49}$ Essentially, Nichirenism placed the strengthening of the Imperial State before religion and peace seeking, unlike the intention of Saint Nichiren. Further, in contrast with Nichiren Buddhism, Tanaka’s Nichirenism distinguished between "good" and "inferior" aggression, and approved the use of "good" aggression which he believed was sanctioned by the sacred text Lotus Sutra and epitomised "universal justice,

\footnotetext{
${ }^{45}$ Sokka Gakkai 創価学会, “'Rissho Ankoku Ron” no teishutsu to hounan”“「立正安国論」の提出と法 難”, Nichiren daishonin no buppou 日蓮大聖人の仏法. Retrieved from URL: http://www.sokanet.jp/pr/kyougakunyuumon/nichirendaishouninnobuppou/nichirendaishouninnogoshougai/03$2 /$.

${ }^{46}$ Rissho Ankoku Ron 立正安国論. Retrieved from URL: http://www.sokanet.jp/kaiin/goshosearch/page.php?n=26., accessed 12 October 2016. The relevant phrase reads: “先ず国家を祈りて須く仏法を立つべし” 47 Tsunoda Jun 角田堯淳, Kokudo jobutsu 国土成仏, online article. Retrieved from URL: http://www.nichirenaomori.net/houwa/h2808_kakutagyoujun/index.html.

48 Tanaka Chigaku, “Reform of Religion” 宗門の医師, Shumon no Ishi.

${ }^{49}$ Edwin B. Lee, “Nichiren and Nationalism”, Monumenta Nipponica 30(1) (Spring 1975), p. 27. See also Tanaka Chigaku, Shumon no Ishin 宗門の維新, p. 27.
} 
religious righteousness”. ${ }^{50}$

According to Hirou Sato and Ruben Habito, Nichirenism was inextricably connected with the rise of nationalism and militarism during the lead up to the Second World War. ${ }^{51}$ Due to unequal treaties Japan signed with Western nations during the Meiji, Taisho, and Showa periods, there was a backlashin the form of “an impelling desire” by Japan's leaders and intellectual elite to make the nation strong. ${ }^{52}$ Edwin B. Lee contemplates that various political events had kindled Tanaka's patriotism, including the successes of the first Sino- Japanese war of 1894 to 1895 (日清戦争) and the Russo-Japanese war of 1904 to 1905 (日露戦争). ${ }^{53}$ Tanaka's Nichirenism, which started as a lay Buddhist movement in 1902 during the Taisho period, was therefore founded on a new interpretation of Nichiren's Buddhist teachings in the context of the increasing consciousness of Japan as a nation-state and as a response to the burgeoning imperialist desires of this state.

\section{The Flourishing of Nichirenism in Manchuria}

Ishiwara Kanji (石原莞爾), a major general of the Kwantung Army in Manchuria in 1937, was an ardent follower of Tanaka's Nichirenism and is best known as a major architect of the 1931 Manchurian Incident which directly led to Japan’s invasion of Manchuria. In The Wind-Up Bird Chronicle, Murakami Haruki described Ishiwara as "the ringleader the year before the staged Chinese attack on Japanese troops known as the 'Manchurian Incident,' the event that enabled Japan to turn Manchuria into Manchukuo - and that later would prove to be the first aggressive act in fifteen years of war. ${ }^{54}$ As the writer and critic Hosaka Masayasu wrote, Ishiwara had envisioned Manchuria as a utopia for mankind (人類の理想 郷 Jinrui no Risogo), and the concepts of “the kingly way” (王道楽土 Oudo Rakudo) and “Ethnic Harmony among the Five Races” (五族協和 Gozoku Kyowa) as applied in the state-

\footnotetext{
${ }^{50}$ Edwin B. Lee, “Nichiren and Nationalism”, Monumenta Nipponica 30(1) (Spring 1975), p. 27. See also Tanaka Chigaku, Shumon no Ishin 宗門の維新, p. 22.

${ }^{51}$ Hirou Sato and Ruben Habito, “Nichiren's View of Nation and Religion”, Japanese Journal of Religious Studies 26(3/4) (Fall 1999), p. 308.

52 Ruben Habito, “The Uses of Nichiren in Modern Japanese History”, Japanese Journal of Religious Studies 26(3/4) (Fall 1999), pp. $424-425$.

${ }^{53}$ Edwin B. Lee, pp. 27-28.

${ }^{54}$ Murakami Haruki, Jay Rubin (trans.), The Wind-Up Bird Chronicle, Random House, 2011, p. 495.
} 
building guidelines and slogans of Manchuria were reflections of Ishiwara's ideology. ${ }^{55}$ Ishiwara wanted to transform the two principles into practical reality in Manchuria.

Coincidentally, these two concepts were the founding state-building principles of the Manchurian puppet state when it was formally established in 1932. In the literal sense, "the kingly way” (王道 Oudo) means the way of the Emperor, and could be interpreted to mean the rule of the righteous. This understanding is exemplified in a related phrase "Oudo to hadou” (王道と覇道) which juxtaposes the two contrasting types of statesmanship “righteous reign” (王道 Oudo) and “tyranny” (覇道 Hado), concepts derived from Confucian philosophy ${ }^{56}$, particularly that of Mengzi (孟子) and his political ideology on "benevolent rule” (王道政治論 Wangdao zhenzhilun). ${ }^{57}$ From a political perspective, “the kingly way” has come to be used as a reference to an ideal land where peace and harmony are achieved. ${ }^{58}$ When applied to the puppet state of Manchukuo (満洲国), the phrase “Gozoku Kyowa” (五族 協和 or Ethnic Harmony among the Five Races) has been used to mean the peaceful coexistence of different ethnic groups residing in Manchuria, namely the Japanese, Manchurians, Chinese, Mongolians, and Koreans. Therefore when Manchukuo was formally created as a “sovereign" state on 1 March 1932, it was to be run by a Government of Manchukuo with Puyi, the last emperor of the Qing dynasty, as President. The Lytton Commission of October 1932, however, considered that the regime was not put in place by a "genuine and spontaneous independence movement”, while the League Assembly in 1933 also concluded that so-called Manchurian independence was moot because "the main political and administrative power in the "Government of Manchukuo" rests in the hands of Japanese offices and advisors. ${ }^{59}$ From the perspective of the international community, the artificial instruments of state put in place under the supposed aegis of "Gozoku Kyowa” in accordance with Ishiwara's ideology, acted

\footnotetext{
${ }^{55}$ Masayasu Hosaka 保阪正康、Taiheiyou sensou wo kangaeru pointo 太平洋戦争を考えるヒント、PHP kenkyousho, 2014.

${ }^{56}$ Brittanica kokusai daihakka jiten ブリタ二力国際大百科事典. Retrieved from URL: https://kotobank.jp/word/\%E7\%8E\%8B\%E9\%81\%93\%E3\%83\%BB\%E8\%A6\%87\%E9\%81\%93-38820., accessed 8 September 2016.

${ }^{57}$ Huang Chun-chieh 黄俊杰, “The Political Thought of Mencius and its Methodological Basis” 孟子的王道 政治論及方法論預設), Historical Inquiry, National University of Taiwan history journal, 16(1991.8), pp. 47-62. ${ }^{58}$ Sanseido daichirin 三省堂大辞林 $3^{\text {rd }}$ edition 第三版, retrieved from URL: https://kotobank.jp/word/\%E7\%8E\%8B\%E9\%81\%93\%E6\%A5\%BD\%E5\%9C\%9F-449219., accessed 8 September 2016

59 “The Resolution of 24 February 1933”, LNOJ Sp Supp no 101/1, 87. See also, Quincy Wright (ed), Legal Problems in the Far Eastern Conflict, New York: Institute of Pacific Relations, 1941, pp. 57 - 58. And James Crawford, The Creation of States in International Law. Oxford University Press, 2006, pp. 78 - 79.
} 
as a veil for actual Japanese dominance in Manchuria.

Another key figure shaping the intellectual culture of Manchuria and influencing its colonial literature was the author Koizumi Kikue (小泉菊枝). The characterisation of Keiran (桂蘭) as played by Ri Koran in China Nights coincides with the character and background of Gui Yu in Koizumi Kikue’s short story Manchu Girl (満州人の少女 Manshujin no shojo).

The story first appeared in the Nichiren Buddhist publication Faith (真 Makoto) in 1938. ${ }^{60}$ It so impressed Kanji Ishiwara that he requested it be republished later that year in the periodical Manchurian Monthly (月刊満洲 Gekkan Manshu). ${ }^{61}$ The story was written by Koizumi Kikue based on her experience as a Japanese woman living in Manchuria between 1935 and 1938. The focus of the story is her interaction with a local housemaid, Gui Yu (桂 玉), who the Koizumi family had hired. ${ }^{62}$ At the outbreak of the Second Sino-Japanese War in 1937, this text was perceived as a "success story" of how Koizumi becomes a surrogate mother, ${ }^{63}$ educating Gui Yu on Japan’s benevolent intentions of "liberating” Asia and eventually winning Gui Yu's heart in spite of the young housemaid's initial anti-Japanese sentiment and support for local insurgents. ${ }^{64}$ It is a prime example of "imperialist motherhood" 65 where the ardent and faithful imperialist in Koizumi draws the colonized people, represented by Gui Yu, under her all-encompassing wing of care and protection in the manner of a mother caring for her child. ${ }^{66} \mathrm{Gui} \mathrm{Yu}$ is described as a young and uneducated girl whose father had passed away and who lacked any understanding and practice of proper hygiene. Gui Yu’s original state is an affront to Japanese civility but she is slowly transformed through the process of education which the Koizumis believe to be their responsibility as subjects of the Japanese Empire.

${ }^{60}$ Clinton Godart, "Nichirenism, Utopianism, and Modernity - Rethinking Ishiwara Kanji’s East Asia League Movement”, Japanese Journal of Religious Studies, vol 42(2), Nanzan Institute of Religion and Culture, 2005, p. 259.

${ }^{61}$ Ibid.

${ }^{62}$ Kimberley T. Kono, "Imperialising Motherhood: The Education of a 'Manchu Girl' in Colonial Manchuria” in Michele Mason and Helen Lee (eds), Reading Colonial Japan: Text, Context and Critique. Stanford University Press, 2012, p. 230.

${ }^{63}$ Regine Mathias, Review of "Reading Colonial Japan: Text, Context and Critique”, Journal of Asian History 47(2), 2013, Harrassowitz Verlag, pp. 263-266.

${ }^{64}$ Ibid, p. 259.

${ }^{65}$ Kimberley T. Kono, p. 227. See also Kathleen Uno, Passages to Modernity: Motherhood, Childhood, and Social Reform in Early Twentieth Century Japan, University of Hawaii Press, p. 148.

${ }^{66}$ Kimberley T. Kono, p. 235. 
Koizumi was a prolific figure in the Nichirenist movements of the 1930s. She joined Tanaka Chigaku's National Pillar Society in 1932 and set up her own women's study group, the Sincerity Association (真会), which received Tanaka's blessing of approval. ${ }^{67}$ While living in Manchuria she became acquainted with Ishiwara. Following in Ishiwara’s footsteps, Koizumi later became a founding member of his East Asia League (東亜連盟協会 Toarenmei Kyokai) which acted as a tool to promote Pan-Asianism in support for Japan's rule over Asia. ${ }^{68}$ In Manchu Girl, Koizumi draws on her belief in Nichirenism to win over Gui Yu's heart by bridging the cultural divide in her proclamation of universal Buddhahood ${ }^{69}$ in all people. She explains to the girl that under Nichirenism, the belief in the equality of all people is not a purely abstract concept but takes physical form in daily life. ${ }^{70}$ She may be alluding to Japan's work to liberate Asia from the unequal treatment of Western powers, which puts Nichirenist ideals regarding the achievement of equality and the realisation of a Pan-Asian utopia into practice.

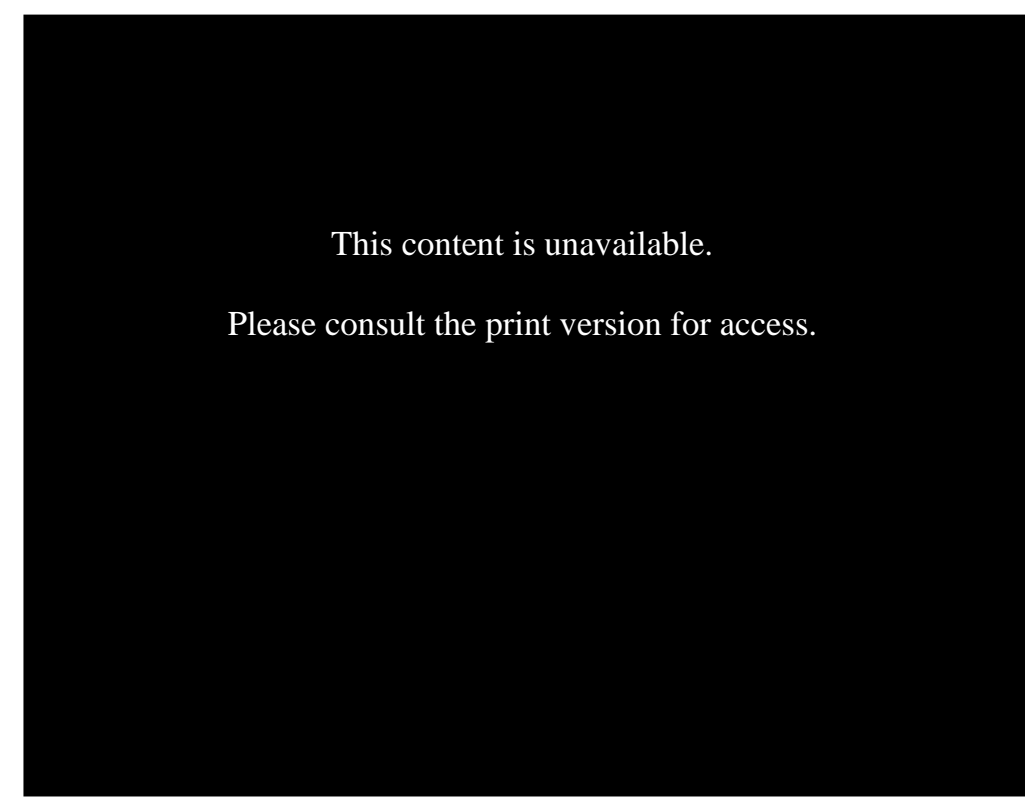

Figure 4 Manchu Girl (1938). Koizumi (left) and Gui Yu (right).

Source: Manchu Girl by Koizumi Kikue (1938).

${ }^{67}$ Clinton Godart, “Nichirenism, Utopianism, and Modernity - Rethinking Ishiwara Kanji’s East Asia League Movement”, Japanese Journal of Religious Studies 42(2), Nanzan Institute of Religion and Culture, 2005, p. 257. ${ }^{68}$ Hideo Kobayashi 英夫小林, “Toa renmei undo: Sono tenkai to higashi ajia no nashionarizumu” “東亜連盟運 動一その展開と東アジアのナショナリズム”, Teikoku to iu genso: Daitoakyoeiken no shiso to genjitsu 帝国 という幻想、大東亜共栄圈の 思想と現実, Tokyo: Aoiki Shoten, 1998, p. 237.

${ }^{69}$ Clinton Godart, p. 259.

${ }^{70}$ Koizumi Kikue, Manshujin no shojo 満洲人の少女, Shinkyo: Gekkan Manshusha, 1938, p. 24. See also Clinton Godart, “Nichirenism, Utopianism, and Modernity - Rethinking Ishiwara Kanji’s East Asia League Movement”, Japanese Journal of Religious Studies 42(2), Nanzan Institute of Religion and Culture, 2005, p. 259. 
Although the Manchurian Film Association (満洲映画協会 Manshueiga Kyoukai) had announced in the April 1940 issue of its official magazine Manchurian Film (満州映画 Manshu Eiga) that it would release a film based on Koizumi’s short story, this film never materialized. There is speculation that plans for the film were axed because it would interfere with the screening of China Nights in June 1940, primarily because the main character of China Nights was largely based on the character of Li Gui Yu in Manchu Girl. ${ }^{71}$

Ri Koran’s character Keiran, as modelled on Koizumi’s Gui Yu, is often understood as nothing more than a convenient marionette meticulously manipulated in a staged performance to promote Japanese Pan-Asian imperialist ideology by fostering a certain kinship among the ethnic groups in Manchukuo, including the Japanese. As Chikako Nagayama contemplates in her essay, Ri Koran "represented the goal of Pan-Asian cultural campaigns, which attempt to erase cultural and linguistic differences by promoting Japanese ‘imperialisation’ among people in the colonies and occupied territories". ${ }^{72}$

The idea of fostering ethnic harmony was not a uniquely Japanese construct and can, in fact, be traced back to the maiden speech delivered in 1912 by the Chinese Nationalist party leader Sun Yat-Sen when he became the first president of the newly-formed Republic of China in the aftermath of the 1911 Xinhai Revolution and the abdication of the Manchu Qing Emperor. In this landmark speech he first described the political concept of "Five Races under one Union" (五族共和 Wuzu Gonghe). ${ }^{73}$ This concept had historical roots in the 1911 Xinhai Revolution’s slogan “Harmony of the Five Races” (五族大同 Wuzu Datong), which originally expressed equality among the Han Chinese and the Manchus, and the unification of Manchus, Han Chinese, Mongolians, Hui, and Tibetans into one national body. ${ }^{74}$ Subsequently the catchphrase “Five Races under one Union” (五族共和) ${ }^{75}$ became a key political slogan in the early days of the Chinese Republic, used to advocate for the harmonious union of the five

\footnotetext{
${ }^{71}$ Manshu Eiga 満州映画, April issue (1), 1940, p. 146.

72 Chikako Nagayama, “'The Continental Melody’ - Soldiers and Japan’s Imperial Screen”, Film Music in 'Minor' National Cinema, Bloomsbury Publishing USA, 2016, p. 91.

${ }^{73}$ Minzu Zhuyi 民族主義, Dr Sun Yat-sen Academic Research Site 孫中山學術研究資訊網. Retrieved from URL: http://sun.yatsen.gov.tw/content.php?cid=S01_03_03_01. Accessed September 2016.

${ }^{74}$ Paul Hibbert Clyde and Burton F. Beers, The Far East: a history of the Western impact and the Eastern response (1830-1970), Prentice-Hall, 1971, p. 409.

${ }^{75}$ Minzu Zhuyi 民族主義, Dr Sun Yat-sen Academic Research Site 孫中山學術研究資訊網. Retrieved from URL: http://sun.yatsen.gov.tw/content.php?cid=S01_03_03_01. Accessed September 2016.
} 
predominant races of China. ${ }^{76}$ Although the Japanese ideology of "Gozoku Kyowa" as advocated in Manchukuo differs in terms of the ethnic groups it intended to unite, the concept of fostering "ethnic harmony” among the diverse groups of people that constitute China would not have been unfamiliar to the local people in Manchuria.

The concept of unification is symbolically conveyed in the five distinct colours of the FiveColour Flag (五色旗 Wuseqi) representing the Republic of China (Figure 5) where the colours in descending order ( red, yellow, blue, white and black) each represent the different ethnic groups of Han Chinese, Manchus, Mongolians, Hui, and Tibetans respectively. The flag of the Japanese-controlled puppet state of Manchukuo adopted a similar colour scheme in its flag, although the proportional allocation of colours on the surface area of the flag demonstrates the greater significance given to the Manchus (represented by yellow) relative to the other groups (Figure 6). Further, the five colours of the Manchukuo flag now represented the dominant ethnic groups in Manchuria, named in descending order as the Japanese, Manchus, Han Chinese, Mongolians, and Koreans.

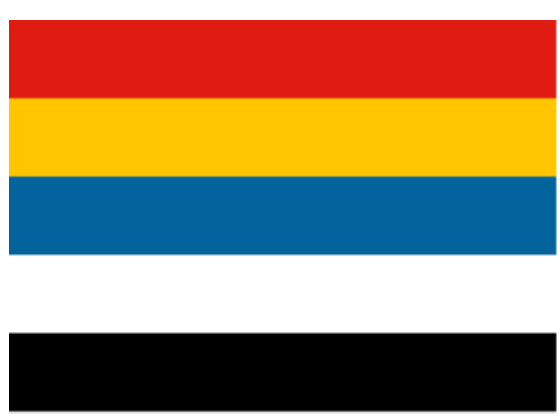

Figure 5 Republic of China Flag (1912- 1928)

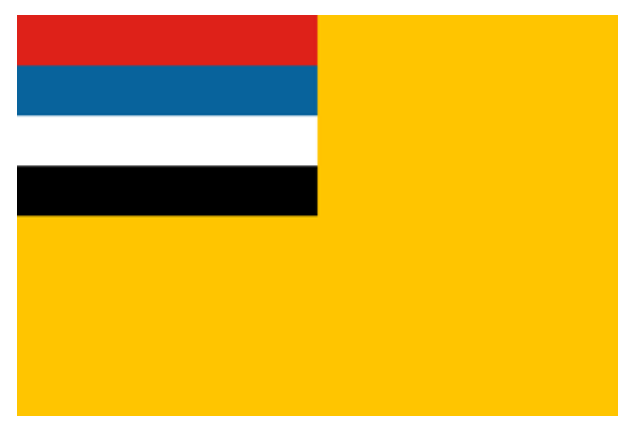

Figure 6 Flag of Manchukuo (1932-1945)

The power of the five-colour scheme to symbolise ethnic unification was employed once again by the Reformed Government of the Republic of China between 1938 and 1940, under the aegis of Japan.

\footnotetext{
${ }^{76}$ Sun Wen 孙文, Zhong Hua Min Guo Lin Shi Dai Zong Tong Xuan Yan Shu 中華民國臨時大總統宣言 書, 1 January 1912. The relevant extract from his speech states: 國家之本，在於人民。合漢、滿、蒙、 、藏諸地方為一國，即合漢、滿、蒙、回、藏諸族為一人。是曰民族之統一。(The foundation of the country lies in the people. The Han, Manchu, Mongolian, Hui, and Tibetan areas are one country, that is, the Han, Man, Mongolian, Hui, and Tibetan ethnic groups are united as one nation) National Dr Sun Yat-sen Memorial Hall, Sun Yat-sen Database, Collected Works of Sun Yat-sen Full Text Retrieval System. Retrieved from URL: http://sunology.culture.tw/cgibin/gs32/s1gsweb.cgi?o=dcorpus\&s=id=\%22DS0000000452\%22.\&searchmode=basic., accessed 9 September 2016.
} 
Figure 7 Republic of the Reformed Government of the Republic of China (1938 - 1940)

\section{The Manchurian Film Association}

The Manchurian Film Association (満洲映画協会 Manshueiga Kyokai or 満映 Man'ei for short) was a Japanese film production company established on 14 August 1937 as a joint venture between the South Manchurian Railway Company and the Manchurian puppet government. Man'ei was to function as a National Policy company (国策会社 Kokusaku Kaisha) which carried the important responsibility of fostering a national spirit in line with the Japanese Pan-Asianist ideology within the puppet state of Manchukuo. ${ }^{77}$ This would involve instilling Japanese culture among the Manchurian population through the medium of film so as to spread Japanese national policy. In an official document entitled "The Strategy and Evolution of the Manchurian Film Association” (満洲国電影政策及び其進化史 Manshukoku denei seisaku oyobi shinkashi), the Japanese Agency of the General State Affairs Council (国務院総 務庁弘報処 Koumuin soumucho kohocho) outlined the role of Man'ei. ${ }^{78}$ The two key principles identified by the Agency as being the spiritual guidelines for Man'ei were first, to establish Manchukuo as a “paradise of the kingly way” (王道楽土), and second to combine “Five Races under one Union” (五族協和) under the leadership of Japan. ${ }^{79}$

Echoing the political intentions of the Japanese government, Amakasu Masahiko (甘粕正彦), the second and most influential Chairman of Man'ei between 1939 and 1945, stressed that the film company's mission was to produce films that would make Manchurians happy, noting that

\footnotetext{
77 “Manei no yakuwari” 満映の役割, CineMagaziNet! 20 (Winter 2016), Kyoto University. Retrieved from URL: http://www.cmn.hs.h.kyoto-u.ac.jp/CMN5/ooba2.html\#chapter2., accessed 12 December 2016.

${ }^{78}$ Komuin soumucho kouhousho “Manshukoku denei seisaku oyoubikishinkashi” 国務院総務庁弘報処「満 洲国電影政策及び其進化」, Gusen 弘宣, Issue 31 (1938), p. 16.

${ }^{79}$ Ibid.
} 
"now what the nation of Japan) calls out for are films that can reach out to and entertain Manchurians. Man’ei should cease pursuit for profit, and must focus on supporting the nation”. ${ }^{80}$

Prior to heading up Man'ei, Amakasu had been a lieutenant in charge of a detachment of the notorious Japanese military police during the chaotic period after the Great Kanto earthquake in 1923. In an infamous incident known as the Amakasu Incident, Amakasu's detachment was mobilised to arrest and brutally murder the political dissidents and anarchists Osugi Sakae and Ito Noe, as well as Osugi's six year-old nephew. ${ }^{81}$ Under the pressure of media scrutiny Amakasu was imprisoned, although his incarceration did not last long. He was released after only three years and sent to France by the Japanese army to study. ${ }^{82}$ The value the army placed on Amasaku was again demonstrated by his posting to Manchuria immediately after his return from France to assist with the army's opium production and smuggling operations.

During Amakasu's leadership of Man'ei, a major trilogy of propaganda films starring Ri Koran, the prime starlet representing Man'ei, was produced, including the 1940 film China Nights. While the first installment of Ri Koran's famous Continental Trilogy, Song of the White Orchid (1939), was set in Manchukuo, the locale of the second film, China Nights, shifted decisively to Shanghai and Suzhou, demonstrating the shift in the focus of Japanese imperialism away from Manchukuo to its ongoing military campaign in China.

Correspondingly, Man'ei, as a National Policy company, extended its reach from its original domain in Manchukuo to Shanghai by participating in a joint venture to acquire a twenty-five percent stake in the China Film Company (中華電影公司 Zhonghua Dianying Gongsi, or 中 影 Zhongying for short and as referred to in this thesis) established in June 1939. The following year, Zhongying participated in the production of China Nights with the Japanese Toho Studios featuring Ri Koran as the lead actress. This marked the expansion of Man'ei's influence into the Chinese market and reflects an extension of Amakasu's plans for Man'ei to foster ethnic unity beyond the borders of Manchukuo and into the wider geographical region of China.

\section{Debuting in Shanghai}

\footnotetext{
${ }^{80}$ Amakasu Masahiko 甘粕正彦, “Manjin no tameni eiga wo tsukuru” 満人のために映画を作る, Eiga Shunpo 映画旬報, 1 August 1942 .

81 Tsunoda Fusako 角田房子, Amakasu Taii 甘粕大尉, Chikumashobo, 2005. Retrieved from URL: http://ktymtskz.my.coocan.jp/cabinet/amakasu.htm\#6., accessed 7 July 2017. ${ }^{82}$ Ibid.
} 
Shanghai of the late 1930s was a great cosmopolitan city. Already in 1931 its population of approximately 3 million consisted of citizens from over 50 countries. Due to the legacy of the unequal Treaty of Nanking which gave away parts of the city to foreign control, the city had been divvied up into three sectors - the International Settlement (公共租界 Gonggong zhujie) where mainly British, American, and Japanese expatriates and soldiers were stationed, the French concession (法界 Fajie), and the predominantly Chinese section where the locals resided. ${ }^{83}$ The Japanese accounted for the highest percentage of foreigners in Shanghai, and had formed an enclave in Hongkou in the International Settlement which was also known as Little Tokyo. ${ }^{84}$

Shanghai was to become the site of one of the worst bloodbaths among the twenty-two major military engagements between the Imperial Japanese Army and the Chinese Nationalist forces fought during the Second Sino-Japanese War. The Battle of Shanghai began in August 1937 and lasted until November that year.

As early as 1932, under the ruse of protecting its citizens, the Japanese navy, then stationed in the International Settlement of Shanghai, often picked fights with the Chinese to provoke seemingly anti-Japanese incidents as casus belli. A classic example was the January 28 incident of 1932 (上海一二八事件 Shanghai yi er ba shijian) in which Japanese forces and Chinese warlord soldiers clashed formally for the first time in Shanghai. Nationalist generalissimo Chiang Kai Shek had held on to his position of "securing internal stability before resisting the external enemy” (攘外必先安内 Rangwai bixian annei) ${ }^{85}$ and sought negotiations with the Japanese. The unequal Song Hu Armistice Agreement, as mediated by British diplomats in Shanghai, was signed by the opposing forces in May 1932. Although Shanghai was declared a non-military zone, Japanese troops were allowed to return to their concession in the city. China, on the other hand, was not allowed to garrison troops in areas surrounding Shanghai, Suzhou, and Kunshan and could only keep a small police force in the city. ${ }^{86}$ This Armistice was seen as an appeasement tactic to satiate Japanese expansionist

\footnotetext{
${ }^{83}$ John King Fairbank et al. (eds), The Cambridge History of China. Cambridge University Press, 1978, p 128132.

${ }^{84}$ SMG Shanghai TV Official Channel 上海電視臺官方頻道, Documentary of life and death - the 1937 battle of Songhu 生死地- 1937 淞滬抗戰實錄.

${ }^{85}$ Zhu Pingchao, Wartime Culture in Guilin, 1938 - 1944: A city at war. Lexington Books, 2015, p. 7.

${ }^{86}$ Zhu Pingchao, p. 4.
} 
greed $^{87}$ but it was an artificial peace that did not last, as demonstrated by the outbreak of the Battle of Shanghai in August 1937.

The result of the bloody battle was the evacuation of Chinese Nationalist forces from the city, a great boost to Japanese control in Shanghai. The Americans, pursuing a policy of isolationism, refused to intervene in line with a "determination to adopt every practicable measure to avoid involvement in war” as declared by President Roosevelt in his Quarantine speech of October 1937. ${ }^{88}$ Meanwhile the British also preferred to pursue a more pacifist route in Shanghai by using diplomacy rather than force, in line with Prime Minister Neville Chamberlain's grand strategy of appeasement. ${ }^{89}$ Chiang Kai-Shek’s hope of international intervention did not materialise and the rest of the world watched from the safety of their concessions as the battle played out until the Chinese were defeated. "It was as though Verdun had happened on the Seine, in full view of a Right Bank Paris that was neutral,” wrote American correspondent Edgar Snow, “as though a Gettysburg were fought in Harlem, while the rest of Manhattan remained a non-belligerent observer." 90

Following the boost to Japan's power after its victory in Shanghai, Britain conceded to Japan's demands for the collection of maritime customs in conquered ports such as Shanghai, a highly lucrative business. ${ }^{91}$ Riding the wave of victory, the Japanese also moved without pausing to take Nanjing, the seat of the national government, where they established a Chinese puppet regime in 1938 known as the Reformed Government of the Republic of China to govern the occupied provinces of Jiangsu, Zhejiang, Anhui, and the municipalities of Nanjing and Shanghai. ${ }^{92}$ These events consolidated Japanese power in Shanghai, the important port city and financial epicentre of China where foreign banks and the Chinese Nationalist Party-

\footnotetext{
87 Ibid.

${ }^{88}$ Franklin D. Roosevelt Address at Chicago on October 5 1937. Retrieved from URL: http://millercenter.org/president/speeches/speech-3310., accessed 18 December 2016.

89 B.J.C. McKercher, "National Security and Imperial Defence: British Grand Strategy and Appeasement, 19301939”, Diplomacy \& Statecraft 19(3), 2008, pp. 391-441.

${ }^{90}$ Peter Harmsen, blog on China in World War II, with comments on 22 July 2013 on “Media War Over”. Retrieved from URL: http://www.shanghai1937.com/media-war-over-shanghai/., accessed in January 2017.

91 B.E. Foster Hall, “The Chinese Maritime Customs: An International Service, 1854-1950”, Occasional Papers No. 5, as part of the Chinese Maritime Customs Project, UK, University of Bristol, 2015 (reproduction of original from 1977), p 34. See also “The Cabinet Papers”, China and Japan. Retrieved from URL: http://www.nationalarchives.gov.uk/cabinetpapers/themes/china-japan.htm., accessed 15 January 2017.

${ }^{92}$ Honda, Katsuichi, The Nanjing Massacre: A Japanese Journalist Confronts Japan's National Shame, M.E.

Sharpe, 1999, p. 283.
} 
controlled financial institutions were situated. ${ }^{93}$

Propaganda needed to keep pace with military expansion. As mentioned earlier, the China Film Company (Zhongying) was established in Shanghai in June 1939, led by Japanese film producer Nagamasa Kawakita and Chinese politician Chu Min-Yi who later became a key person in Wang Jing-Wei's collaborationist Reorganised National Government of the Republic of China from March 1940 to April 1945. Man'ei had a twenty-five percent stake in China Film Company. This investment was a strategically-designed move that paved the way for Man'ei's star Ri Koran to make her next move into the competitive Shanghai market, thereby expanding her singing and acting career beyond Manchuria and into China. In spring of 1940 Ri Koran's important National Policy film, China Nights, was swiftly released as a collaboration between Man'ei and Zhongying.

In summary, Ri Koran's success as a film star and a singer during the Second Sino-Japanese War was by no means an accident. In fact, it was the result of a carefully designed and wellplanned project tailored to the imperialist needs of Japan, taking into account the historical environment of Manchuria, China, and Japan at the time. Historical events can be traced to parallel the trajectory of Ri Koran's meteoric rise as a singer and film star with a career that is replete with political significance. She was born in Manchuria at a time when Nichirenism was active through the activities of Japanese believers from various social backgrounds in Manchuria, such as the army officer Kanji Ishiwara and the author Koizumi Kikue. These figures played significant roles in the dissemination of the "Hakko Ichiu” ideology while the establishment of the National Policy film company Man'ei in 1937 would ensure that Ri Koran could be nurtured into a living embodiment of "Hakko Ichiu”. Through a Continental Trilogy of National Policy films that were the combined efforts of scriptwriters, directors, and composers under the auspices of Man'ei and other entertainment companies stationed in Shanghai, Ri Koran became a film star and singer whose success was inextricably tied to the spread of imperialist propaganda. Japan's military success in Shanghai also contributed greatly to creating a more stable platform for Ri Koran to enter the Chinese market. Here she could continue to lend her physical beauty, voice, border-crossing bilingualism and cultural

\footnotetext{
${ }^{93}$ Chen Zhen Ling and Long Deng Gao 陳爭平，龍燈, “Ri jun zhan qu de zhimindi jingji” in zhong guo jingdai jingjishi jiaocheng “日軍占區的殖民地經濟” , 中國近代經濟史教程, Qing hua da xue chu ban she you xian gong si 清華大學出版社有限公司, 2012, p. 299.
} 
sophistication to the work of creating a Greater East Asia Co-Prosperity Sphere under Japan's leadership. 


\section{Chapter Two}

\section{China Nights (1940) - A Case Study of Sedating Discontent}

In tandem with Japan's military aggression in China, Ri Koran's acting career was rapidly developing. The second film of her Continental Trilogy, China Nights, was released in June 1940. Unlike the film before it, Song of the White Orchid, China Nights was set in Shanghai instead of Manchuria. The film transformed Ri Koran's screen image from an innocent Manchurian girl to a victim of the war. The film reflects the vivid reality of war-time China, and insinuates that the only way out for China is to amalgamate with Japan under the ideology of "Hakko Ichiu”.

China Nights, directed by Osamu Fushimizu, was produced through a collaborative effort involving Toho Studios (東宝) and the China Film Company (中華電影) in which Man'ei had a twenty-five percent ownership. The screenplay was written by the celebrated Japanese screenwriter Hideo Oguni who was perhaps better known for his famous post-war film "To Live” (1952), which he co-wrote with Akira Kurosawa. Like the other two films of the Continental Trilogy, the main story-line of China Nights appears to be no more than a romance between a Japanese man and a Chinese girl, played by Hasegawa Kazuo and Ri Koran respectively. Although China Nights was the most well-known of the three films in the Continental Trilogy, its wartime love story theme was heavily criticised by the army, film critics, and film censorship office for its “degeneracy” and "lack of contribution” to the war effort. ${ }^{94}$ After all, as Takahisa Furukawa claimed, the impression of the film was nothing

\footnotetext{
94 “Zatankai: Kokubou to kokka to bijitsu - Gakka wa naniwo nasubekika” 座談会: 国防国家と美術一画家は 何をなすべきか (Forum, “National defence, nation and art - What Shall Artists Do?”), Mizue art magazine, 1941 (1) “みづ总” 美術雑誌 1941 年 1 月号. See also “Shin eigahyo” 新映画評, Asahi Shimbun 朝日新聞, 1940 (June 9). “Kenetsu no madokara nippon eigakaini tsuite” 検閲の空から 日本映画界について, Shin eiga 新映画, 1941 (8), p. 64.
} 
more than simple entertainment. ${ }^{95}$

The criticism is precisely what makes this propaganda film stand out. The opening scene of the film starts with a quarrel between an unfortunate young Chinese girl Keiran (played by Ri Koran) and a middle-aged Japanese man. She is helplessly defending herself by repeating that she had never intended to prostitute herself for money. Clearly the Japanese man is nothing more than a bully. He insists the money he has given the girl was meant for more than just a meal and accuses her of not fulfilling her promise. The audience may start to wonder why this Japanese film would want to discredit its own people right from the start, which does not look promising as a Japanese propaganda film. As the famous Japanese adage “Teki wa honnoji ni ari” (敵は本の寺にあり) ${ }^{96}$ hints, the conspiracy of the actual is not what we have seen. The adage references an historical event from the Edo period and describes a situation in which the real motive is in fact hidden behind a façade. China Nights was more than just a story of love; it was an educational demonstration of the ultimate Sino-Japanese relations. Its sugarcoated storyline and songs blur the vision of the audience such that they become completely under the sway of Ri Koran's undeniable beauty and euphonious voice.

Hase, the leading male character, first appears in the film to rescue Keiran from the angry and unpleasant Japanese man, even though both Hase and his companion are Japanese as well. This act of natural instinct on Hase's part helps him to stand out from the Chinese crowd in the station. He kindly reminds the unpleasant Japanese man of the goodness of the Japanese people. Further on, Hase even sets himself up as the living example of his own principles by offering money to compensate his fellow Japanese man's financial loss, and thus gently forces the latter to withdraw from the fight. Hase's awareness of his need to be a morally upright person is reflected in his opinion that Japan should always remember its duty to behave righteously in front of China, and it is this steadfast belief that forbids him from abusing his position of authority over the Chinese in Shanghai. After Hase rescues Keiran from trouble, he pays no attention to Keiran's offer to pay him back for his help. He is confused by her gratitude because as a Japanese man, what he did to help the poor girl was only natural instinct

\footnotetext{
${ }^{95}$ Furukawa Takahisa 古川隆久, “Sensoushita no nippon eiga - hitobito wa kokusakueiga wo mitaka” 戦時下 の日本映画 人々は国策映画を見たか, Yoshikawa koubunkan 吉川弘文館刊 129, p. 130.

${ }^{96}$ This phrase translates as "The enemy is in Honnouji Temple."
} 
and therefore he does not expect his actions to be appreciated. By this point, Hase has redeemed the good name of the Japanese and won the hearts of the Chinese. Instead of making an ally of his fellow man, Hase takes Keiran's side. Hase's actions manifests the duty of Japan to set itself as the exemplar for China.

\section{Keiran - A Stereotype or an Unconventional Character}

Ri Koran's character Keiran is introduced from the beginning as a feisty heroine with more than a pretty countenance for the audience to easily fall in love with. Keiran's voice is highlighted from the start of the opening scene, even before we visually locate her on-screen in a scene busy with the ebb and flow of passing pedestrians. We first learn of her presence when we hear her angry denials ring out above the din of the busy Shanghai streets as she exclaims in fluent Mandarin that she is not the sort of person who would accept something for nothing. By restating her point, she successfully delivers her message and clears her name. Keiran is clearly a strong-willed, opinionated, and vibrant character who makes her presence clearly felt within the film itself and to her audience. For the Japanese, the phrase “Yamato Nadeshiko” (大和撫子) refers to the personification of the archetypal Japanese woman, known for her virtue and beauty. Normally, women of this type are humble, calm, and respecting of a man's place in society. Unfortunately, Keiran is the very opposite of "Yamato Nadeshiko". She is outspoken, independent, and confident and holds her ground as an equal in a male-dominated society.

These almost alien foreign qualities of a woman would not have been unfamiliar to Chinese audiences. In the classical Chinese novel, Dream of the Red Chamber (紅樓夢), one of the twelve beauties (十二金釷 shier jinchai), Wang Xi-Feng, offers literary evidence of a precedent “Weijian qiren, xianwen qisheng” (未見其人，先聞其聲). ${ }^{97}$ This description of Wang Xi-Feng's first appearance in the book fits in precisely with Keiran’s characterisation. Keiran is a woman with a strong will and a distinctive personality. Once she has set her mind on an issue, she will not be persuaded otherwise. This quality of her character makes the

\footnotetext{
${ }^{97}$ Guo Yu-Wen 郭玉雯, “Hongloumeng” Yuanyuanlun: Cong shenhua dao mingqing sixiang 《紅樓夢》淵 源 論: 從神話到明清思想, Guoli Taiwan daxue chubanzhongxing, 2006, p. 321. The phrase can be translated as “To hear of a person before seeing her (him).” In the context of Wang Xi-Feng, this may be a reference to her voluminous voice that corresponds with the power of her aura as a woman with a strong, outspoken character.
} 
process of convincing her to embrace the Japanese harder. Nevertheless, the end-result is rewarding. Ri Koran however described her own personality as a young girl differently to the nature of Keiran in the autobiography, Fragrant Orchid - The Story of My Early Life. In the prewar years she was a "naïve young girl, swept by the currents of the time" and "just a very ordinary girl who knew nothing about the world". ${ }^{98}$ Contemplating her personal history as a wartime actress, she stated regrettably in an interview published in the September 2003 issue of Sekai, "I feel great guilt for having played a Chinese woman useful for Japanese purposes." 99

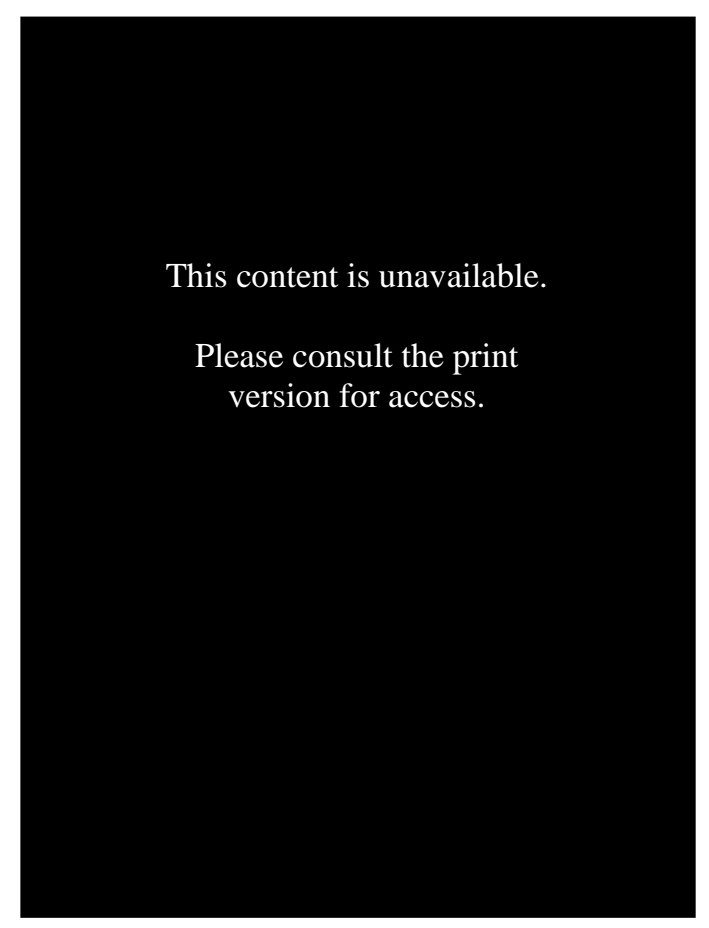

Figure 8 Ri Koran at nineteen years of age (1939).

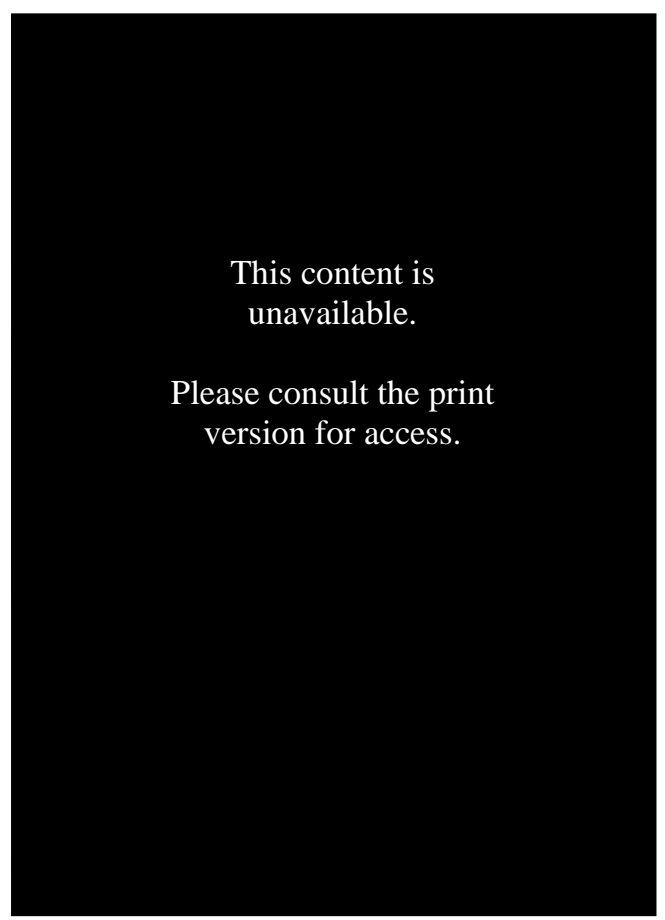

Figure 9 Ri Koran as Keiran in China Nights (1940).

In the ongoing war, Japan had invaded central China and taken control of provinces and municipalities, including Shanghai. However the war also took its toll on Japanese lives, as demonstrated by the price they paid in conflicts such as the Battle of Zaoyi (霜宜會戰, 1940) in which the Chinese put up stiff resistance. In the film, Keiran's actions and her character draw a vivid picture of how the Chinese resisted Japan’s imperialist aggression.

\footnotetext{
98 Yamaguchi Yoshiko and Fujiwara Sakuyu, Fragrant Orchid - The Story of My Early Life, University of Hawai'i Press, 2015, p 2.

99 Tanaka Hiroshi, Utsumi Aiko and Onuma Yasuaki, Looking back on my days as Ri Koran (Li Xianglan), The Asia -Pacific Journal (Japan Focus), volume 2(10) Oct 11 2004, p 1.
} 
The physical beauty of Ri Koran is showcased through the character Keiran throughout the film, adding to the audience’s sympathy and affection for her. Ri Koran was popular among young Japanese women and men as a "fleshy" beauty. ${ }^{100}$ However it is not just Keiran's physical appearance that draws Hase's and the audience's attention. Her appeal derives from her tragic situation, her love for her family, and her moral strength, elements that combine to create a memorable character able to win the hearts and minds of her Japanese audience. Yet in existing academic literature, Keiran is often treated as a stereotype. Naomi Ginoza, for instance, has described Keiran as a stereotypical "delinquent-looking”, frail character, but bearing an "urbane eroticism” and the “charm of degeneration”. 101

In describing Keiran as such, Ginoza positions Keiran’s characterisation within the Orientalist mode of representation, i.e. the stereotyping of the foreign other, and goes a step further to the efficacy of such "stereotyped characterisation" in a propaganda film. Her viewpoint reflects a general academic tendency to label the characterisation of Keiran in China Nights as wartime Japanese Orientalism” ${ }^{102}$. In a similar vein, John Whiteclay Chambers considers how Japanese propaganda films during the war created personas for different countries along deeply-biased gender lines. China is personified as a weak, vulnerable woman while Japan is identified with the male hero and with "imperialist ideology of national pride, power and paternalism”. ${ }^{103}$ However, as I demonstrate below, the character Keiran as played by Ri Koran is more ideologically complex than an Orientalist stereotype. Ri Koran's film is best understood within the historical context of the Sino-Japanese War rather than the theoretical framework of Orientalism borrowed from a European perspective.

\section{Quelling Discontent through Film}

Even before the release of China Nights in June 1940, voices of discontent towards the war were growing in fortitude within Japan. In hindsight, the rising sense of disapproval may

\footnotetext{
${ }^{100}$ Igarashi Yoshikuni, Bodies of Memory: Narratives of War in Postwar Japanese Culture 1945-1970. Princeton, NJ: Princeton University Press, 2000, p. 18.

${ }^{101}$ Naomi Ginoza, Dissonance to Affinity: An ideological analysis of Japanese Cinema in the 1930s. Phd Dissertation, UMI, 2007, p. 284.

102 John Whiteclay Chambers and David Cuthbert, World War II, Film and History. Oxford University Press, 1996, p. 40.

${ }^{103}$ Ibid.
} 
have, in fact, contributed to the need for a response from the Japanese government to its public by way of a suitable propaganda film. According to Yoshimi Yoshiaki, the first half of 1940 was a historical turning point for Japan. The Japanese population was suffering from war weariness as there did not seem to be an end in sight for the Second Sino-Japanese War. There was increasing dissatisfaction with the focus on militarism abroad as in the rural areas of Japan, domestic labourers were forced to enlist and horses were drafted into service. In the cities, prices soared, black markets grew, and daily necessities like rice were in short supply. ${ }^{104}$ Overall, life became increasingly harsh on the home front.

The result of the decline in living conditions and the cruel realities of war were increasingly criticised, including in the discontent raised by lawyer and politician Saito Takao, who questioned the significance and necessity of waging war with China. In a parliamentary speech in February 1940, Saito expressed scorn for the proclamation by Japanese leaders of Japan's worldwide mission to bring everlasting peace in accordance with "international justice and the spirit of 'the whole world under one roof"'” (Hakko Ichiu), considering this to be an unrealistic dream. ${ }^{105}$

In the month following Saito's speech, on 30 March 1940, the Japanese government moved to establish a rival political regime to the Chinese Nationalists in the form of the Reorganised National Government of China based in Nanjing. This would be led by Wang Jing-Wei, a former high-level official of the Nationalist government and confidante to Sun Yat-Sen.

Wang Jing-Wei had been selected to head the regime because he was a champion of lasting peace between China and Japan, expressing his view that China should collaborate peacefully with Japan in an essay entitled “Advancing Together” published on 1 January 1940. ${ }^{106}$ The puppet regime of the Reorganised National Government operated from the original seat of power of the Nationalist government in Nanjing, and its principal purpose was to portray itself as the legitimate successor to Sun Yat-Sen while discrediting the current Nationalist

\footnotetext{
${ }^{104}$ Yoshimi Yoshiaki, Grassroots Facism: The War Experience of the Japanese People. Columbia University Press, 2015, pp. 58-59.

${ }^{105}$ Lawrence Fouraker, “Saito Takao and Parliamentary Politics in 1930s Japan”, Sino-Japanese Studies 12(2), April 2000, p. 17.

${ }^{106}$ Wang Jing-Wei, Advancing Together, 1 January 1940. Retrieved from URL: http://www.wangjingwei.org/zh/his-ideas-cn/political-writings/\#1447608474748-8d565e5f-adb4.
} 
government in Chongqing under General Chiang Kai-Shek. ${ }^{107}$ While Chiang Kai-Shek and the Nationalists had fled to Chongqing, the Reorganised Government controlled Japaneseoccupied Jiangsu, Anhui, parts of Zhejiang, Shanghai, Hankou, and Wuchang. However, the spirit of the Chinese could not be easily broken; many refused to submit to Japanese authority, and hundreds of thousands continued to migrate west up the Yangtze and south to the southwestern provinces, as they had done ever since the Japanese insurgency began in 1937 and as it continued to spread throughout the entire eastern seaboard of China. ${ }^{108}$

In China, Wang Jing-Wei's puppet regime was roundly detested. An editor of the China Weekly Review wrote that "since the occupation of the Shanghai outskirts by the Japanese invaders and their 'running dogs,' headed by Wang Jing-Wei, this city, which was formerly known as a metropolis of peace and order, has now become a place of horror." ${ }^{109}$ Back in Japan, the outspoken politician Saito also expressed scepticism at the ability of the Reorganised Government to establish order in China and great concern that Japan's support for Wang would mean a long war against Chiang Kai-shek's regime and would therefore impose a huge burden on the Japanese population. ${ }^{110}$

China Nights attempts to quell the voices of discontent rising up even within Japan by projecting a positive image of marriage and by extension, political marriage, between the Chinese and the Japanese. The establishment of the Reorganised Government symbolises a political marriage or alliance between China and Japan. Rejecting the possibility of peace negotiations with Chiang Kai-Shek, Japan's strategy for achieving stability and control in China was to turn to Wang Jing-Wei. China Nights presents a positive image of the marriage of Keiran and Hase by portraying them as a loving couple with a relationship based on mutual respect. It provides confidence to the audience that this relationship will go the distance and

\footnotetext{
107 Torsten Webster proposes that Chinese collaboration with the Japanese as championed by Wang Jing Wei was "part of an integrated attempt at seeking political legitimacy by claiming the intellectual heritage of Sun Yat-sen” and "Wang's Asianism, therefore, was a "a restoration of Sun Yat-sen's Asianism”. Torsten Webster, “Nanjing's Greater Asianism: Wang Jingwei and Zhou Huaren, 1940”, Pan-Asianism: A Documentary History, 1920 - Present, Rowman \& Littlefield Publishers, 2011, p. 209.

108 Diana Lary, Chinese Migrations: The Movement of People, Goods and Ideas over Four Millennia, Rowman \& Littlefield Publishers, 2012, p. 119.

${ }^{109}$ The China Weekly Review, 29 March 1941, p. 109.

${ }^{110}$ Lawrence Fouraker, “Saito Takao and Parliamentary Politics in 1930s Japan”, Sino-Japanese Studies 12(2), April 2000, p. 19.
} 
that in the long run, peace will prevail once present difficulties or resistance are overcome.

As propaganda to persuade Chinese viewers to support the newly established Reorganised Government, the film confronts the tragedy of the lost and attempts to alleviate their grief. In fact, this served the purpose of providing some form of justification for the wartime violence inflicted by Japan on China. By 1940, Japan had already introduced to the Chinese, Manchurian, and Japanese public, as propaganda, various Pacifist concepts such as "Hakko Ichiu”, "Gozoku Kyowa” and the Greater East Asia Co-prosperity Sphere, which served to bolster Japan’s manifesto on "peace” and "harmony” in Asia under its leadership. However these lofty ideals, championed by the Japanese government and disseminated by National Policy films, contrasted starkly with the brutality that Japan actually wreaked on China during the war.

In May 1940, one of the worst series of Japanese bombings of Chongqing commenced. Approximately one month after the start of the air raids, China Nights was released. The aerial attacks on Chongqing, where Chiang Kai-Shek’s Nationalist government had relocated after the Nanjing Massacre, consisted of a protracted period of intensified bombing in a military offensive known as “Operation 101”. This offensive lasted from 18 May to 4 September 1940 and unleashed the fury of 27,000 bombs on Chongqing alone. ${ }^{111}$ Following soon after the start of the German Blitzkrieg, the carpet bombing transformed Chongqing into a hellfire that is captured well in this report by the chief military officer of the Shanghai Secret Military Agency to the Naval Ministry:

Efforts to battle the fires were in vain as the urban area was transformed to a berserk fury, totally engulfed in flames...countless dead bodies were seen floating downstream. ${ }^{112}$

To a limited extent, China Nights attempts to respect the history of the Japanese destruction of China. After Keiran's arrival at the Japanese hotel where Hase and his friends reside, she

\footnotetext{
${ }^{111}$ Hans van Ven, China at War: Triumph and Tragedy in the Emergence of the New China 1937 - 1952, Profile Books, 2017. See also Haruo Tohmatsu and H.P.Wilmott., A Gathering Darkness: The Coming of War to the Far East and the Pacific, Rowman \& Littlefield Publishers, 2004, pp. 79 - 80.

112 Yuki Tanaka and Marilyn B. Young, Bombing Civilians: A Twentieth Century History, The New Press, 2010, pp. $148-149$.
} 
discovers a familiar face from her past in the character of Zhou Ma, an elderly housemaid from her old residence.

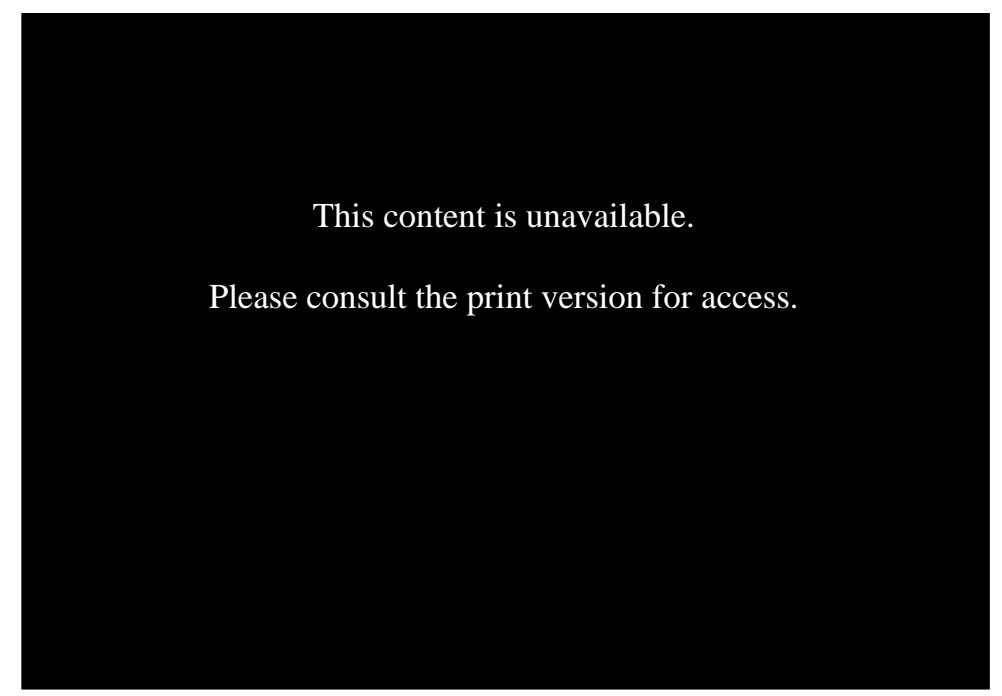

Figure 10 Keiran reunites with Zhou Ma, her former housemaid, in China Nights.

This is the first scene in which Keiran recognises a familiar face after the tragic loss of her entire family and her family home in the fighting in Shanghai. Eventually the Japanese army occupied the Chinese-controlled parts of Shanghai. Like a child who has been forcibly separated from her mother, Keiran collapses into the arms of Zhou Ma. China Nights does not conceal the fact that Keiran, like many other Chinese, has lost family to the Second SinoJapanese War. In this reunion scene, Keiran and Zhou Ma can finally release their grief and mourn for their loss of loved ones.

The purification of devastation created by the Japanese attack on Chinese cities is exemplified in China Nights when we see Toshiko, one of the Japanese lodgers and an admirer of Hase, visiting the graves of people who had died on the same site of devastation where Keiran's family once lived (Figure 11). 
This content is unavailable.

Please consult the print version for access

Figure 11 Toshiko paying her respects to war dead

Toshiko lays flowers of commemoration before the tombstones erected on the site, but the film does not reveal the identities of the people. Were they Japanese soldiers who were Toshiko's friends or family members? The audience is left to speculate. Glancing up, she spots Keiran's lonely figure a short distance away, grieving in the midst of the rubble. Toshiko rushes over and attempts to persuade Keiran to return to the hotel and stop Hase from worrying about her. Toshiko advises Keiran to place Hase’s feelings before her own grief for the loss of her loved ones. At this point, we may recognise one of the strategies of the film as a propaganda piece. By aligning Toshiko's commemoration of war dead with Keiran's mourning of her family, the film attempts to demonstrate that the Japanese grieve for the dead just like the Chinese, thereby placing the two parties on equal terms, sharing in the same experience of grief. This comparison may be seen as a cinematic sleight-of-hand to purify the image of the Japanese. However, this deliberate construction of synonymy between the Japanese and Chinese acts of mourning is deeply misleading because it blurs the boundaries between perpetrators and victims. In so doing, the film creates a false consciousness about history through manipulation of fact.

Essentially, the film positions Toshiko as the image of the mainstream Japanese woman and a counterpoint to Keiran. The differences between these two characters can be easily distinguished in two ways. First, Toshiko is attentive towards Hase, as she always stands by his side and provides unconditional support to her beloved man, even though she knows Hase 
is in love with Keiran. In contrast, Keiran always expresses her resistance towards Hase. She never quite shows her care for Hase, until he has over-exhausted himself by looking after Keiran when she falls ill.

Second, the audience can distinguish between Keiran and Toshiko by the volume of their voices. Toshiko is always quietly and gently reasoning through her feelings and concerns. Keiran, on the other hand, speaks readily and quickly. She expresses her feelings and emotions openly, and may sometimes even be seen as overly forthright and inconsiderate. Toshiko hides her true feelings for Hase because she believes that only Hase can rescue Keiran from the agony of her past. Once again, the film recreates another version of Hase, a self-sacrificing character to assist Keiran’s ultimate redemption.

Those scenes thus become moments of relief as the tragic loss created by war is both vocalised in the verbal exchange of intimate emotions between Keiran and Zhou Ma and visualised through these characters embracing one another and sobbing on each other's shoulders, as well as in the act of Toshiko paying respects to the war dead. By opening up these wounds and confronting the tragedy of war, this scene tries to create resonance in both Japanese and Chinese viewers as witnesses to and participants in the same war. Ri Koran however had not experienced suffering from the loss of her family. But as a child while living in Fushun, she did witness an unforgettable scene of a middle-aged Chinese man being cruelly murdered by the Japanese military police in public. ${ }^{113}$

In fact the Japanese and Chinese took on opposite roles - the former as the aggressor and the latter as the victim of violence brought on by war. This vital difference is deliberately downplayed in China Nights, for instance, in the contrast between carefully constructed scenes of destruction in the film and historical footage, and the parallel drawn between Keiran and Toshiko, a Japanese woman lodging at the hotel.

113 Yamaguchi Yoshiko and Fujiwara Sakuya, My Fushun Years, Fragrant Orchid - The Story of My Early Life, University of Hawai'i Press, 2015, p 7. 
This content is unavailable.

\section{Please consult the print version for} access.

Figure 12 Keiran wanders through the rubble of Shanghai

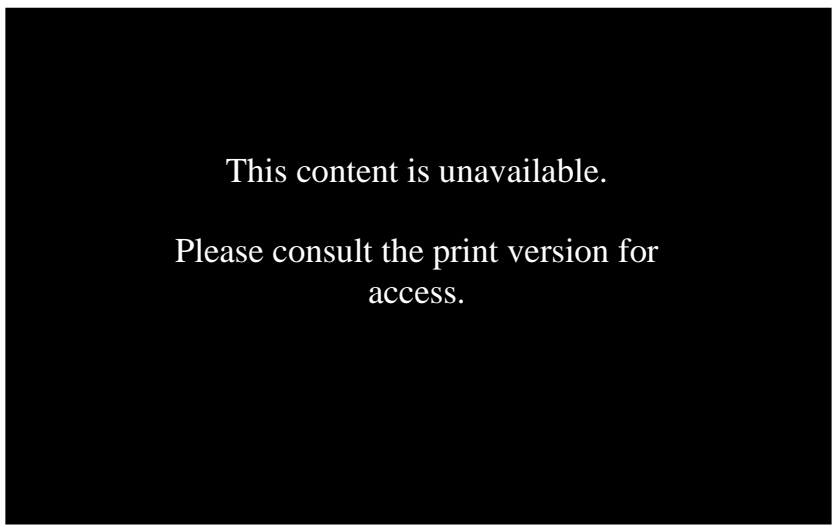

Figure 13 The destruction of Shanghai

Source: https://kknews.cc/history/lpr5nbg.html

In one of the scenes (Figure 12), Keiran makes a lonely sojourn through the rubble of a destroyed section of Shanghai where the bombed-out skeletons of buildings are the best evidence of war. In this truly depressing sight, the solitary figure of Keiran traverses this landscape of tragedy accompanied by solemn, stately music. The painful memories of conflict in Shanghai remain fresh in Keiran's mind as she grieves for a second time on-screen for the loss of her dearest family members and the destruction of her home. Images of destroyed buildings are probably a reference to the Battle of Shanghai which had taken place three years before, in 1937. The vulnerable, solitary figure of Keiran as a poor child in mourning, grieving in the midst of the debris, is a powerful visual image intended to evoke empathy rather than hostility because the audience is reminded of their own vulnerability and of the frailty of human life itself. Rather than demonstrating any signs of aggression, Keiran focuses on mourning her loss, an experience the Japanese audience can share. 
The film chooses to confront certain aspects of the undeniable cruelty and agony of the war, perhaps in an attempt to make the film appear less propagandistic. By linking the film to the current environment, and releasing the grief of war experienced by Keiran, the film comes much closer to the day-to-day life of citizens, thereby making the narrative more convincing. The emotions expressed by the film's characters become irresistibly vivid.

However, the film still manages to act as a screen, sanitising the blood and gore of wartime reality. The barren landscape and the wreckage left behind by war as depicted in China Nights during Keiran's lonely sojourn resonate with images of ruin taken during the Japanese Operation 101 bombings of Chongqing that commenced in May 1940. The relentless assault ravaged the city. Although the photographs of the actual bombings (Figure 13) are remarkably similar to scenes in China Nights, the reality of war was far more horrific than in the film (Figure 12), where evidence of the massacre of the Chinese populace has been cleanly removed from the crime scene. Unlike the photographs of Chongqing which demonstrate the intensity of raw emotional power, scenes from China Nights are quietly sentimental in a way that desensitises the audience to a true appreciation of the gruesomeness of war. The separation of reality from film reflects how distant everyday life of the ordinary China citizen was, ironically, from Japan's lofty ideals of creating "Hakko Ichiu” or "Gozoku Kyowa" among the different peoples that constitute Asia. The film, contrary to its propagandist intentions, accentuates the fact that the "peace" and "harmony" that a Greater East Asia Coprosperity Sphere was meant to deliver were merely empty promises and propaganda material peddled to the public.

\section{Family - The Justification of Violence under "Hakko Ichiu"}

Like Toshiko, many Japanese characters in the film can be identified or interpreted as "goodwill” ambassadors between Keiran and Hase. These characters unite or cooperate under the same moral principles as Hase. China Nights serves as an advertisement for this type of person. They live under the same roof - the Japanese hotel - and look out for each other, sharing, caring, supporting, and loving whoever is in need. In this foreign land, Shanghai, "family" is key. 
China Nights, as a propaganda film, is designed to prompt an attitude and a behavioural change in its audience. Under the concept of "Hakko Ichiu”, the film creates unity among Keiran, Hase, and the Japanese lodgers at the hotel who are shown to embrace Keiran as part of their "family". By extension, this symbolically represents the embrace of China as part of the "family" by the Japanese in accordance with the concept of creating a Greater East Asia Co-prosperity Sphere. The "Hakko Ichiu” ideology is invoked in several scenes of the domestic interior which revolve around the subject of family and familial unity.

After their initial meeting, Hase brings Keiran to his hotel where all the lodgers except Keiran are Japanese. They adopt this Chinese orphan and look after her as their own child, demonstrating understanding and love despite her initial hostility towards them.

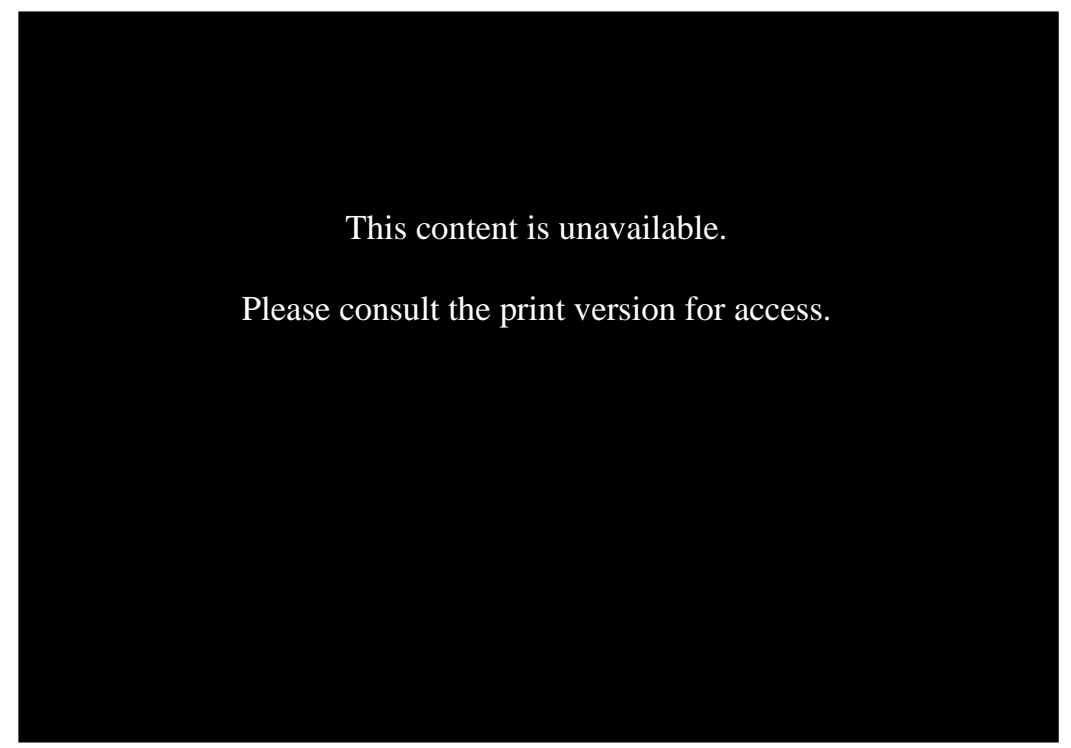

Figure 14 Japanese lodgers watching over a sick Keiran

In the scene depicted in Figure 14, Keiran has collapsed with a high fever after visiting the ruins where her family home once stood before the war reduced it to rubble. Like worried family members watching over their sick child, the Japanese lodgers anxiously await the doctor's diagnosis while crowding in Hase's room where Keiran lies bedridden. Although Keiran is not visible from this camera angle - her bed in the right corner is obscured by onlooking members of her newly adopted family - her presence is nevertheless strongly felt because everyone's line of vision is focused on the same spot in the room and the conversation revolves around her. She is thus shown to be a key person in this family. 
In Chikako Nagayama's review of Ri Koran's first film in the Continental Trilogy, Song of the White Orchid, she highlights a particular scene of the domestic interior that bears a “striking resemblance” to "Hakko Ichiu” ideology because the scene draws on the subject of family and family unity to invoke the concept of "(combining) eight directions under one roof”. ${ }^{114}$ The domestic scene of Keiran and her new Japanese “family”, described above serves a similar function.

Historically, the concept of the Japanese state as a family unit, known as “kazoku kokka” (家 族国家) was formally established in Japan in the 1890s during the Meiji era. The traditional family system was invoked to represent the imperial Japanese state with the emperor as the symbolic parent and the citizens expected to treat him with the respect and love accorded a "strict father or loving mother". ${ }^{115}$ Practically, such "family-state” ideology was a systematic way of organising the Japanese population by allocating each person or group their rightful position and expected duties under the authority of the Emperor. Joanne Liddle and Sachiko Nakajimo describe this system of social regulation as "a hierarchy structured by gender, class and nation”. ${ }^{116}$ The family-state emphasizes familial unity under the leadership of a single authoritative figure. This can be related to the concept of "Hakko Ichiu”, in which various elements or members are consolidated under a single "roof” as one family unit. The portrayal of a gathering of family members in China Nights visually establishes the structure of a family with the Japanese hotel lodgers acting as loving relatives to Keiran, the sick Chinese girl. By symbolic reference, then, the formation of a new family with Japanese and Chinese members becomes a projection of "Hakko Ichiu” ideology where the concept of "family" has extended beyond the boundaries of Manchukuo, where Song of the White Orchid was set, to China, where Japanese aggression was focused by 1940.

\footnotetext{
${ }^{114}$ Chikako Nagayama, Fantasy of Empire: Ri Koran, Subject Positioning and the Cinematic Construction of Space, PhD Dissertation. University of Toronto, 2009, p. 81.

${ }^{115}$ Sharalyn Orbaugh, “Gender, Family and Sexualities” in Joshua S Mostow (ed), The Columbia Companion to Modern East Asian Literature, Columbia University Press, 2003, p. 44.

116 Joanne Liddle and Sachiko Nakajimo, "The Defeat of the Militarist Project", Rising Suns, Rising Daughters: Gender, Class and Power in Japan, Zen Books, 2000, p. 134.
} 
This content is unavailable.

Please consult the print version for access.

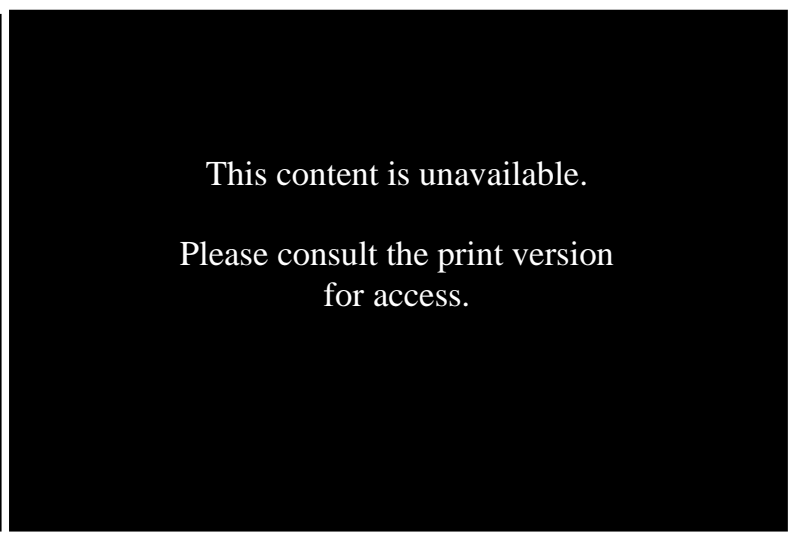

Figure 16 Hase cares for Keiran through the night

Figure 15 Hase comforts a sick Keiran

Hase, the key element of the imperial Japanese concept, takes on the responsibility of looking after Keiran through the night. The projection onto Hase of the fatherly role towards Keiran continues in the ensuing scene where Keiran, delirious with fever, cries out pitifully for her mother to hold on to her hand. At this crucial point, Hase reaches out for her flailing hand and comforts her (Figure 15). Rather than a messianic figure capable of divine healing, Hase acts in the capacity of a loving father figure who watches over Keiran like a guardian angel. His loving kindness, demonstrated in the thoughtful dedication with which he cares for Keiran through the night (Figure 16), eventually restores Keiran back to health. The benevolence of Hase can therefore be viewed as a symbol for the strength of Japanese moral character. His actions powerfully advertise the idea of “Hakko Ichiu” in the context of Japan's proposed Greater East Asia Co-prosperity Sphere, which promised Japan's stewardship and a helping hand in forging a common prosperous future for all states involved. The film encourages its Japanese audience to embrace a worldview that fits with the Japanese imperialist narrative. The Japanese observer becomes Hase: righteous, self-aware, morally impeccable, respectful, and accepting of the Chinese people but firm in disciplining “errant” behaviour. As the cogs of the Japanese war machine continued to turn in the late 1930s and early 1940s, it was crucial for the government to rally the support of its people and to boost their morale as their family, friends, and lovers were shipped off to fight the brutal war at the frontlines in China.

In contrast with Hase's kindliness towards Keiran, China Nights introduces violence as a necessary step towards becoming "family". In one of the defining scenes, Keiran is slapped across the cheek by an infuriated Hase as punishment for her ingratitude for the Japanese 
lodgers' concern for her safety and well-being. This moment of startling violence comes after Keiran's lonely sojourn amidst the rubble of her family home where she reminisces about her original family. The violence inflicted on Keiran by Hase appears to be a form of tough love. By slapping Keiran to her senses, she completes an initiation rite that allows her to formally become part of the "family" of Japanese lodgers with Hase as her lover and soon afterwards, as her husband. In this moment of transition Keiran changes from being hostile to falling in love with Hase. Through the slapping incident, the "family" comprised of both Japanese and Chinese members becomes reality. The underlying message of the film appears to be that violence is an intrinsic element that completes the equation of "family" by bringing its members together. This incident is analysed in more detail later in this chapter in a discussion of the use of silence in China Nights as a cinematic device for disseminating propaganda.

This "family" concept has been showcased by the Japanese Imperial Song and Dance Troupe (皇軍慰問団 Kougun Imondan) which called on various Chinese actresses and singers to accompany Ri Koran to perform popular songs in both Japanese and Chinese at various venues in China. The aim was to deliberately emphasise the “協和” (kyouwa) and “共榮” (kyouei) elements under the ideology of "Hakko Ichiu”.

\section{Marriage - The Symbolic Completion of "Hakko Ichiu”}

If the Japanese hotel represents a united family, then no stronger ties would hold it together than marriage. The prominent marriage scenes between the two protagonists distinguish China Nights from the other two films of the trilogy. Marriage is one of the most sacred forms of recognition between two people/families. The purpose of these scenes is to legitimise the relationship between the two lovers. As a result, society and civil law recognise their rights as husband and wife.

In China Nights, the marriage of Hase and Keiran contains powerful symbolism. Scholars of China Nights have recognised that their marriage "symbolises the union between Japan and China”. ${ }^{117}$ Kimberley Kono suggests that the development of Hase and Keiran’s relationship

${ }^{117}$ Kimberley T. Kono, Romance, Family and Nation in Japanese Colonial Literature, Springer 2010, p. 17. 
into marriage aligns with "the use of (these) films to promote the colonial project". ${ }^{118}$ In a similar vein, the film scholars Joseph Anderson and Donald Richie comment that through the symbolic marriage between the protagonists, "virile Japan (is) happily bedded with effeminate China". ${ }^{119}$ The underlying political connotation therefore is that "Japan was rescuing China... The two were to live in peaceful co-prosperity ever after." ${ }^{120}$ Although the subject of "marriage" has been extensively discussed in existing scholarship and its symbolic relationship with the spread of Japanese imperialism clearly identified, the question of why marriage is significant to China Nights in the Continental Trilogy remains. There are also unanswered questions regarding the role that $\mathrm{Ri}$ Koran, as a historical figure, plays in this symbolic marriage and her unique importance as "the bride of Japan”, questions that could deepen our understanding of what purpose marriage serves in this propaganda film and its effect on the audience. To better understand these questions, I analyse two scenes from the film relating to the marriage of Hase and Keiran. In the first, preparations for the wedding ceremony are a prelude to the wedding night, while the second depicts the dress code of the wedding night, in which Hase and Keiran are on the balcony of their hotel overlooking the Shanghai nightscape.

After Hase successfully rescues Keiran, he proposes to her by asking her to never leave his side ever again. On the night of the wedding ceremony, the lodgers in Hase and Keiran's hotel are busy decorating the place for their wedding. Notably, Chinese cultural elements have deliberately been given priority. Distinctive Chinese lanterns bearing the surnames of Hase and Keiran as “長谷” and “張” (Figure 17) are put up to mark the festive occasion. The symbolic meaning of hanging lanterns in Chinese custom comes from the character " 灯”, which has a similar pronunciation as “丁”, defined as a male or son in the Kangxi Dictionary (康熙字典). Therefore lanterns represent prayers that a newly-married couple will successfully produce offspring. In China Nights, this symbolism of carrying on a lineage is important as a representation of the continuity of union between Japan and China.

\footnotetext{
${ }^{118}$ Kimberley T. Kono, Romance, Family and Nation in Japanese Colonial Literature, Springer 2010, p 17. ${ }^{119}$ Anderson, Joseph I, Joseph L. Anderson and Donald Richie, The Japanese Film: Art and Industry, rev. ed. Princeton University Press, 1982, p. 155.

${ }^{120}$ John Whiteclay Chambers, “China Nights”, World War II, Film and History, Oxford University Press, 1996, p. 40.
} 
This content is unavailable.

Please consult the print version for access.

Figure 17 Lanterns at the wedding of Hase and Keiran

As part of the wedding ceremony, another important Chinese element is prominently displayed in the film. Paper-cuttings of the Chinese character “喜” (xi) decorate the walls of the hotel (Figure 18). This Chinese character is a cultural necessity at Chinese weddings because it means "double happiness" and symbolises marital bliss. Although Keiran is to be married to Hase, her identity as Chinese is respected and she is allowed to retain it even in marriage. This resonates with the "Hakko Ichiu" ideology, particularly in terms of the Greater East Asia Co-prosperity Sphere, which promises “collaboration” 121 rather than "authoritarianism”. It is understood that loss of cultural identity is not a natural consequence of a collaborative effort, but a necessary result of the conformity demanded by authoritarianism.

121 “Statement by the Prime Minister Prince Fumimaro Konoe”, Tokyo Gazette 2(2), 1939, p. 23. Retrieved from HeinOnline, Law Journal Library, URL:

https://heinonline.org/HOL/LandingPage?handle=hein.journals/tokygaz3\&div=12\&id=\&page=, accessed 23 October 2017 
This content is unavailable.

Please consult the print version for access.

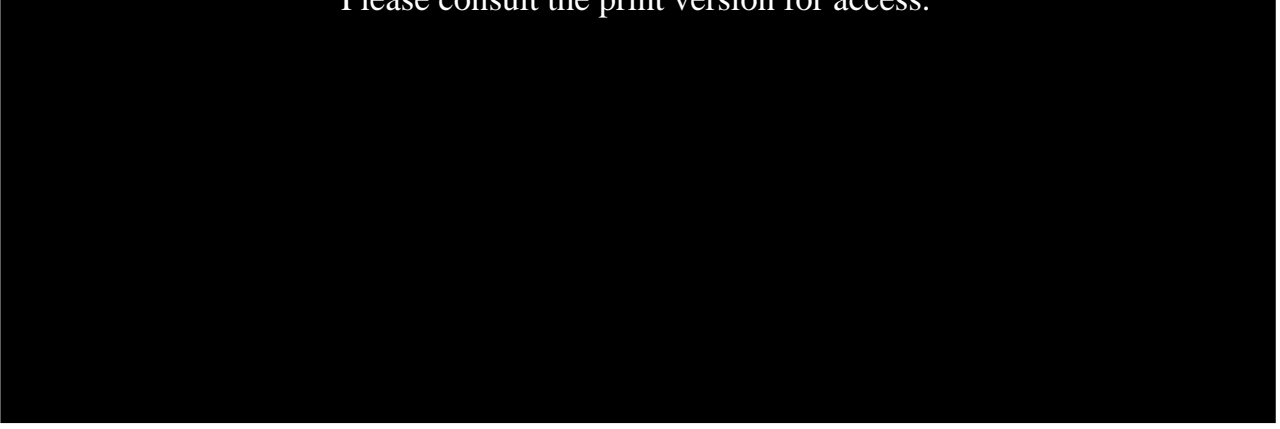

Figure 18 The hotel with traditional Chinese wedding decorations

The marriage between Keiran and Hase is an attempt to visually bring together two different cultures. Visually, through the use of props such as the festive decorations, the film achieves a fusion of Chinese and Japanese culture in the marriage celebration. This reinforces the ideology of "Hakko Ichiu” by reminding the audience of its core concept of uniting different cultural and ethnic groups. The idea of creating a "union" in line with the spirit of "Hakko Ichiu” is outlined in the basic draft plan for the establishment of the Greater East Asia CoProsperity Sphere, a concept that followed Prime Minister Fumimaro Konoe's earlier vision in 1938 of a New Order in East Asia. ${ }^{122}$ Then Foreign Minister Hachiro Arita alluded to it in a radio address in June 1940 regarding “The International Situation and Japan’s Position”123 and it was formally announced later in 1940 by the new Foreign Minister, Yosuke Matsuoka, in a press interview. ${ }^{124}$ The draft plan itself discusses the Japanese empire as striving for the achievement of “Hakko Ichiu”, which is “the spirit of (Japan’s) founding”. The draft outlines plans to establish unions in various parts of the world "to let countries and peoples develop their respective abilities in peaceful cooperation and secure livelihood”. ${ }^{125}$ Of note is the East

\footnotetext{
122 Steven Hoadley and Jürgen Rüland, Asian security reassessed, Institute of Southeast Asian Studies, University of California, 2006, pp. 48-49, 63.

${ }^{123}$ William Theodore De Bary (ed), Sources of East Asian Tradition: The modern period, Columbia University Press, 2008, p. 622.

${ }^{124}$ James L. McClain, Japan: A Modern History. W.W. Norton Company, 2002, p. 47

125 William Theodore De Bary (ed), Sources of East Asian Tradition: The modern period, Columbia University Press, 2008, pp. 312 - 313.
} 
Asia Union which aims to achieve "the unification of Japan, Manchukuo and China in neighbourly friendship" by "settlement of the Sino-Japanese problems through the crushing of hostile influences in the Chinese interior”. ${ }^{126}$ As part of the proposed Union, Japan will function as the "stabilizing power".

Another key scene on Keiran and Hase's wedding night depicts the two main characters on the balcony of the hotel against the iconic backdrop of the Shanghai nightscape with its glimmering neon lights. This scene would have been familiar to Japanese residing in the cosmopolitan city. For those who had not travelled to Shanghai, it would have captured the essence of a great cosmopolitan city. To emphasize their location, the flashing characters "Shanghai” appear in the bottom left-hand corner of the screen (Figure 19). Hase is dressed in a Japanese naval uniform whereas Keiran dons a traditional Chinese cheongsam in pristine white. In the 1920s, the cheongsam began to absorb the influence of Western fashion as reflected in the shortening of the hem and the tightening of the waistline to highlight the shapeliness of the female form. By the 1930s it was in vogue as a statement of the modern woman and was associated with the desirable traits of the Chinese woman - sophistication, culture, subtlety, and quiet beauty. ${ }^{127}$ By dressing in a beautiful white cheongsam and a translucent Western veil, Keiran is fashioned into the epitome of the elegant, modern woman who combines traditional virtue with twentieth century sophistication. Her Chinese identity is retained because she neither wears a kimono nor a European-style wedding dress. According to Karl Gerth, costume can be a "nationalistic commodity spectacle" that creates “nationalistic visuality”. ${ }^{128}$ At least in outward appearance, Keiran’s Chinese identity is not usurped although she marries Hase and their fates become intertwined.

Marriage symbolises a blissful union and emphasizes the concept of "family" by officialising the formation of a family unit. Under the institution of marriage, Keiran is the legitimate spouse of Hase and can now produce legitimate offspring. Their wedding celebrates the

\footnotetext{
${ }^{126}$ William Theodore De Bary (ed), Sources of East Asian Tradition: The modern period, Columbia University Press, 2008, pp. $312-313$.

${ }^{127}$ Huang Min 黃敏, “Minguo shiqi de fuzhuang yanjiu”民國時期的服裝研究，Suzhou daxue shehuixueyuan 蘇州大學社會學院，Zhuzhou gaodeng zhuankexuexiao xuebao 株洲示範高等專科學校學報 10(4), 2005, p 13.

${ }^{128}$ Karl Gerth, China Made: Consumer Culture and the Creation of the Nation, Harvard University Asia Centre, 2003, p 10.
} 
formation of a family. The film tells the Japanese audience that the violence of war shall eventually provide China with happiness in the long-run, and the stability of a marriage between Japan and China provides certainty for an uncertain future. China Nights essentially provides a moral high-ground for the Japanese audience to stand on. Although Keiran and, by association, China, are welcomed as "family" in the film, in reality there was a massive military confrontation from 1 May to 18 June 1940 between the Japanese army and the Chinese Nationalist troops which left over thirty-seven thousand Chinese soldiers dead. The Battle of Zaoyi (霜宜會戰) coincided with the release of China Nights on 5 June 1940, and resulted in the Japanese occupation of Ichang ${ }^{129}$ which provided an advantageous airbase for Japan to launch air attacks on Chongqing where the Nationalist government was based. These crucial two months proved to be a turning point for the Nationalist forces which suffered serious setbacks in the war against Japan. On the other hand, marriage in China Nights can be seen as merely a mirage of the utopia promised by Japan, laden with irony and mired in historical false consciousness because in reality, the Japanese army used brute force to crush Chinese resistance.

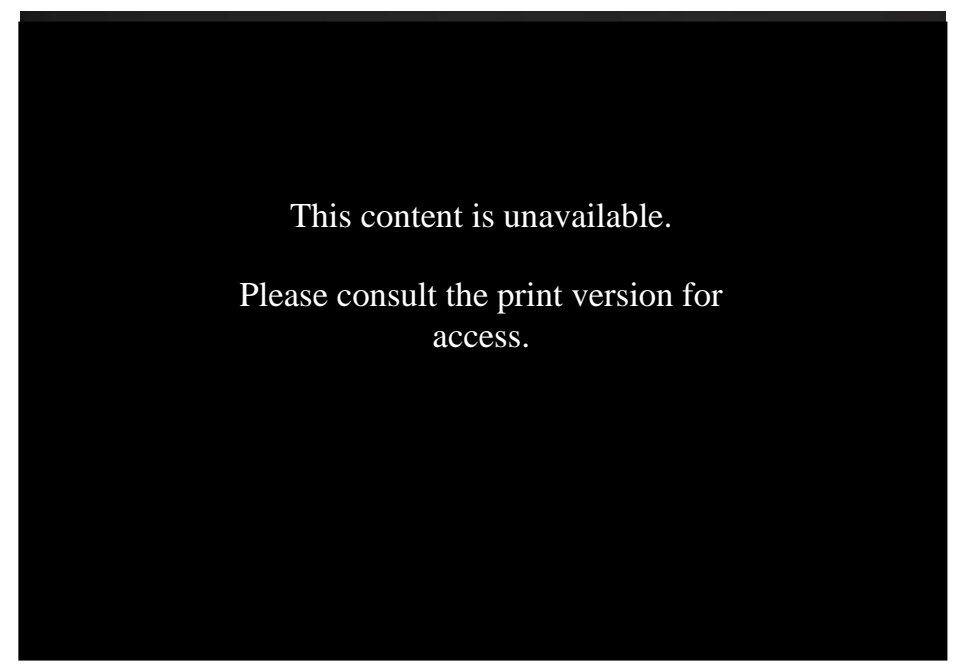

Figure 19 The wedding night in Shanghai

\footnotetext{
${ }^{129}$ Boeicho boeikenshusho senshishitsu 防衛庁防衛研修所戦史室, Shinajihen rikugun. Sakusen (3) Showa 16 nen 12 gatsumade 支那事变陸軍作戦（3）昭和十六年十二月まで, Asakumo shinbunsha, 1975, pp. $214-215$.
} 


\section{Silence - Eloquence without Words}

Silence is a literary technique that has been used to communicate messages to an audience, sometimes in ways so powerful that it may even exceed the most eloquent speech or lavish writing. The observation that silence can eclipse sound in terms of expression is exquisitely expressed by the Tang Dynasty poet Bai Ju-Yi in his poem “Song of the Pipa” (琵琶行 Pipa xing): “silence proves more befitting of the moment than sound” (此時無聲勝有聲 Cishiwusheng shengyousheng).

As a cinematic technique, the skillful use of silence can create the most powerful moments of humanistic expression. The absence of sound may deepen the texture of an actor's performance in film as it heightens the dramatic effect of a particular moment. Silence can communicate various messages. Robert Bolt delivers an astute observation on silence in his play, A Man for All Seasons: ${ }^{130}$ "So silence can, according to the circumstances, speak!"

In China Nights, silence has been used cleverly and with the effect of heightening the propagandistic element of the film. It is portentous or heraldic; even when there is no actual sound, the film and its characters "speak.” In several significant scenes silence indicates a dramatic turn of events or raises tensions both on-screen in the narrative and off-screen in the audience engaged in the film.

Keiran is a vocal character in the film. Her nature is emphasized through her conversations with Hase and with the other Japanese lodgers. Her feelings are expressed by her voice even when she is semi-conscious. However, some of the most critical scenes of this "voice-made" character were silenced in the film.

The first significant silence occurs immediately after the dramatic moment when Hase slaps Keiran across her cheek in a flare of uncontrollable rage, such is the force of his anger and disappointment with her that Keiran crumples to the ground, holding her cheek. In her autobiography, Living as Ri Koran, Ri Koran (Yamaguchi Yoshiko) recounts that Hasegawa actually slapped her so harshly during their performance for the film that she bled and was

\footnotetext{
${ }^{130}$ Robert Bolt, A Man of All Seasons, Globe Theatre premiere, 1 July 1960. The play revolves around the historical events in 1535 during the reign of King Henry VIII. Sir Thomas More refuses to endorse the king's wishes to divorce his wife and establish himself as the head of the Church of England. The above quote is taken from the scene in which More is on trial for high treason and Thomas Cromwell is his accuser.
} 
taken to the hospital. ${ }^{131}$ For almost half a minute, the main characters do not utter a single word. The tension unleashed with Hase's outburst evaporates into stunned silence with the audience as onlookers. This then rapidly evolves into anticipation with bated breath for the moment when silence brims over into some form of response to Hase's actions. In this case, silence heralds a new development in the relationship between Hase and Keiran. During the brief but significant silence, Keiran experiences physical pain and undergoes an emotional struggle as to whether or not she should confront her true feelings of affection towards Hase. This is a difficult decision because on the one hand she realises, through the "awakening" process of the brutal slap, that she is in love with Hase, her benefactor. But on the other hand, to accept romantic love would mean betraying her past. In this caesura of sound, the film evokes the communicative power of silence to say the unsaid, to articulate Keiran's emotional struggle which would have been difficult to express verbally in an acceptable manner. We are briefly reminded of Bai Ju-yi’s poem, "Song of the Pipa”, where he contemplates how silence may eclipse sound in the expression of the deepest emotion. It is appropriate thus to apply silence as a cinematic technique here because the dramatic change in Keiran's attitude is the fulcrum on which the development of "Hakko Ichiu” ideology turns in this film. Silence heralds the progression of Hase and Keiran's relationship towards romantic love.

This, however, is in fact quite an incongruous turn of events. Recounting her life as Ri Koran, Yamaguchi Yoshiko writes that the physical pain she felt when Hase slapped her did not compare with the pain of humiliation China experienced from such a pathetic performance of Chinese subservience in response to Japanese use of force, as symbolised by Keiran's response to Hase's outburst.

The next silence comes in a series of scenes in which Hase travels through night-time Shanghai to meet Keiran, who has been abducted. Hase travels in a car driven by an anonymous driver, speeding through the streets of Shanghai towards the mysterious residence where Keiran has been held captive by her anti-Japanese cousin. This is another rare moment of the film when noise is emptied, and silence is pregnant with suspense. In

\footnotetext{
${ }^{131}$ Yamaguchi Yoshiko, Ri Koran wo ikite: watashi no rekishisho “李香蘭”を生きて：私の履歴書. Nippon Keizai Shinbunsha, 2007, p. 60.
} 
this circumstance, silence becomes portentous of what lies ahead for Hase and Keiran. Hase is on the way to complete his mission to rescue his beloved, but the audience cannot be sure that he will succeed. Viewers experience a déjà vu moment here as they remember the first meeting between Hase and Keiran when she was initially introduced to the audience by her voice rather than her image on-screen. At that meeting, Hase's attention was caught by her voice as it presented her emotions and described her predicament. As the audience, we recognised the hopelessness in her voice, and followed it. In the initial appearance, Keiran was identified by Hase but this time the situation is different. As viewers we have not yet been informed of Keiran's situation and whereabouts, but Hase's anxiety is unmistakable. We sense that Keiran's sudden absence from his side and her withdrawal from our sight signals that she may be in some form of danger. Again, Hase goes to her rescue. It is a pattern we have witnessed before in the opening scenes of the film.

The use of impregnated silence is a familiar theatrical technique. Silence brings to the fore that which is unsaid, unheard, and unseen, but not necessarily unfelt. There is a long interval of silence and as observers, our patience is tested with the ticking of the clock in the background. Interestingly, it is Keiran who initiates the discontinuation of silence, making a sudden move to overturn a table lamp with a great crash. The lights are out in an instant; the silence that was present is replaced by vivid sounds - scrambling, shouting, more crashes, and then gunshots. When the visuals finally return, we find Keiran and Hase are reunited and, in fact, are brought even closer to each other than ever. It is as if the absence of sound was preparation for this union. Silence was always waiting to be broken, meant to be broken. It announces the ending of an old era and the coming of a new age.

Keiran prays to "kamisama" (this refers to "god" in Japanese) that this blissful happiness of love between her and Hase never ends. As the lovers stroll through Suzhou, her lilting voice floats as an accompaniment in the background to the song “Soshu Yakyoku”. Her next prayer is in Mandarin as she kneels before a giant statue of a Buddha in what appears to be a Chinese temple. This time her prayer is for the safe return of her Japanese husband from his naval mission. By this time, Keiran and Hase are already tied in matrimony. The prayer she utters is of significance because it represents one of the few lines in the film that she speaks in Mandarin and it comes at a time when she is officially recognised as "Hase no Okusan" (Hase’s wife) rather than by her own name Keiran. In terms of both social status and naming 
conventions, she is no longer a separate individual from Hase, symbolizing the desired relationship between China and Japan. Effectively, the consolidation of Keiran and Hase's relationship is a visual and emotional manifestation of what Japan's proposed policy of creating a Greater East Asia Co-prosperity Sphere aimed to achieve - a close bond of collaboration between China and Japan politically, economically, and geographically, tethering their fates to each other.

In the film, the marriage between Keiran and Hase is celebrated and blessed with the wellwishes of Hase's circle of Japanese friends. As viewers, we may recall that what is happening on-screen comes just three years after the Battle of Shanghai, which saw the defeat of the Chinese Nationalist army there, and the occupation by Japan of the Nationalist-controlled parts of Shanghai. The Japanese moved quickly to create a semblance of Chinese control over the Japanese-occupied regions such as Shanghai and Nanjing by creating puppet regimes, including the Reformed Government in March 1938 and the Reorganised Government in Nanjing in 1940. The historical background reconciles with scenes in the film of bombed-out buildings and of a distraught Keiran revisiting the crumbling ruins which were once her family home in Shanghai. However in a change of heart and a twist of fate, China and Japan join in matrimony, symbolising "Hakko Ichiu" and projecting the ideal Sino-Japanese relationship. The political messages underlying this twist in the storyline are powerful - love and marriage can happen even between enemies, conflict is temporal, and there can be lasting and peaceful coexistence. Keiran's suicidal actions upon receiving misinformation about Hase's death further reflect Japan's frightful conspiracy - the desire to become China's lifeline and therefore to have the power to control its fate.

Ri Koran portrayed a misfortunate Chinese girl awaiting her ultimate redemption. To dilute the atrocities of war and white-wash its barbarity, propaganda films became one of the most convenient tools of imperial Japan under the aegis of the "good-will” ideology of "Hakko Ichiu”. Unfortunately, Japan's good-will did not parallel their actions in reality. Ultimately, it could not convince the general public to believe that all the lives sacrificed were for a better world. China Nights is a mirage of Japan’s hallucinatory empire. 


\section{Chapter Three}

\section{Continental Melodies - Extension of the Propaganda Narrative}

“Soshu Yakyoku” (蘇州夜曲) was the very first Japanese-composed song featured in Ri Koran's films that was custom-made for her. She was the original singer of "Soshu Yakyoku" in China Nights. ${ }^{132}$ This was driven by the young singer-actress' burgeoning fame, particularly in Japan, as a result of the box-office success of her National Policy films. Through the vehicle of Continental Melodies, which were specially written or selected to accompany Japanese National Policy films, China Nights was not only able to keep its propaganda purpose hidden under the veil of music, it was also able to sustain this purpose by emphasizing and expanding on the imperialist ideology of "Hakko Ichiu”.

Continental Melodies were either adopted or created as the musical accompaniments to scenes in National Policy films. These films were characterised by their propagandistic focus on creating "continental goodwill” to justify acts of war by Japan on other Asian countries which it forcefully sought to place within the Greater East Asia Co-Prosperity Sphere. The musical genre developed during the 1930s and 1940s in response to both political necessity and a growing public interest in China attributable to Japanese media hype of the Second SinoJapanese War. While the call for war would have been a directive from the upper echelons of Japanese government, practically, it was the ordinary Japanese citizen who was subject to a universal conscription system that had been enforced since the Meiji period by the Japanese military $^{133}$. The experience of war on the battlefields of Manchuria and China would therefore

\footnotetext{
${ }^{132}$ In an interview with the Asia-Pacific Journal, Ri Koran recalled how Hattori Ryoichi had commented, "I wrote the best song I could for Ri Koran”. "Looking back on my days as Ri Koran”, The Asia-Pacific Journal 2(10), Oct 11 2004. Retrieved from URL:

http://apjjf.org/-Onuma-Yasuaki--Utsumi-Aiko--Tanaka-Hiroshi/1571/article.pdf., accessed 16 December 2016. "Soshu Yakyoku" was first released with the film China Nights in June 1940, as sung by Ri Koran. Subsequently in August 1940, it was recorded by Watanabe Hamako and Kirishima Noboru. Retrieved from URL: http://rekion.dl.ndl.go.jp/info:ndljp/pid/1315518, accessed 16 December 2016.

${ }^{133}$ Yoshida Yutaka 吉田裕, Nihon no guntai: Heishitachi no kindai shi 日本の軍隊一兵士たちの近代史, Tokyo: Iwami Shoten, 2002, p. 3.
} 
have been a quintessential part of the Japanese public consciousness and inseparable from modern Japanese life in the 1930s and 1940s. Naomi Ginoza addresses the gap between "an obsessive awareness of 'being a nation'” and the "prevalence of modern culture” by putting forward the proposition that "the practice of the cosmopolitan culture enabled civil society to enjoy national confidence in achieving modernity". ${ }^{134}$ War and imperialism form a permanent part of Japanese history, while the associated sentiments of trauma, grief, and frustration cannot be separated from Japanese memory at an individual level.

Contemplating the indispensability of music in a time of war, Leon Botstein, a conductor and president of Bard College in New York, cites the musicologist Guido Adler’s 1915 essay “The Art of Music and the World War” in support of the view that music possesses ethical properties and is universal. ${ }^{135}$ Taking a step further, Botstein contemplates that because of this ability of music to transcend divides, it has functioned as a double-edged sword, both to encourage peace and to elicit powerful emotions of exclusivity and superiority that motivate war. ${ }^{136}$ I demonstrate here that Continental Melodies crossed intangible borders, enabling this genre of music to function effectively as propaganda in support of the National Policy films it accompanied. This is especially captured in Continental Melodies during the Second SinoJapanese War. Evolving from their Chinese origins in terms of scale, rhythm, and sound, Continental Melodies successfully crossed cultural borders, becoming deeply entrenched in the hearts of the two warring nations, China and Japan. As Edgar Pope suggests, embedded within Continental Melodies are unique "musical signifiers" that elicit specific sentiments or imageries. The use of the pentatonic scale commonly employed in traditional Chinese music, for instance, is capable of conjuring images of China by way of imaginative references communicated through songs. ${ }^{137}$ This chapter demonstrates that Continental Melodies, through the voice and image of Ri Koran, have proven their "border-crossing” ability.

\footnotetext{
${ }^{134}$ Naomi Ginoza, Dissonance to Affinity: An Ideological Analysis of Japanese Cinema in the 1930s, UMI, 2007, p. 12.

135Leon Botstein, “Classical music: Why music in a time of war?”, The New York Times, March 3, 1991.

${ }^{136}$ Ibid.

${ }^{137}$ Edgar W. Pope, Songs of Empire, PhD Thesis. University of Washington, 2003, pp. 377 - 382.
} 


\section{Sugar-coating “Hakko Ichiu”}

Continental melodies (大陸メロデイ Tairiku Merodei), a popular Japanese music genre of the 1930s and 40s, were mostly created for propaganda purposes. According to Chikako Nagayama, Continental Melodies are considered “representative of Japan’s colonialist culture during World War II" as they evoke the stereotypical imagery of places in China. ${ }^{138}$ Continental Melodies' popularity was driven by the Japanese public's growing interest in China as a result of the hype of the Second Sino-Japanese War. Such music fired the imagination of the listener and complemented the National Policy films set in China.

Michael Bourdaghs considers that Continental Melodies were part of "counterfeit culture" that recreated “Chineseness”. Drawing on Edward Said’s critique of Orientalism, Bourdaghs seizes upon the Orientalist tropes and ideas prevalent in eighteenth-century European and British literature and art that he has identified in Continental Melodies, and contends that these popular melodies "engaged in a game of masquerade" by pretending to voice the emotions and thoughts of a racialized other. ${ }^{139}$ He suggests various similarities between Continental Melodies and American blackface minstrelsy, an indigenous theatrical form "popular from the early $19^{\text {th }}$ and early $20^{\text {th }}$ Century that was founded on the comic enactment of racial stereotypes”. ${ }^{140}$ Blackface performers were white travelling musicians who painted their faces black to caricature black slaves, entertaining a predominantly white audience with song and dance. ${ }^{141}$ Bourdaghs proposes that blackface minstrelsy is similar to Continental Melodies in that both parodied another culture by appropriating cultural forms, thereby creating a "counterfeit culture". ${ }^{142}$ One such instance of "counterfeit” culture was the song "Soshu Yakyoku” (referred to as Suzhou Serenade by Bourdaghs). ${ }^{143}$ Borrowing the term “Orientalism” commonly used to critique European Colonialist art and literature, Bourdaghs argues that Ri Koran and her performance of Continental Melodies were examples of “Asian-

\footnotetext{
${ }^{138}$ Chikako Nagayama, “'The Continental Melody” - Soldiers and Japan’s Imperial Screen”, Film Music in 'Minor' National Cinemas, Bloomsbury Publishing USA, 2016, p 91.

${ }^{139}$ Michael K. Bourdaghs, “Japan's Orient in Song and Dance”, Sino-Japanese Transculturation: From the Late Nineteenth Century to the End of the Pacific War, Lexington Books, 2012, p 168.

${ }^{140}$ Encyclopaedia Britannica. Retrieved from URL: https://www.britannica.com/art/minstrel-show, accessed 2 February 2017.

${ }^{141}$ Exhibition on the History of Minstrelsy, "African American Minstrel Performers". Retrieved from URL: http://exhibits.lib.usf.edu/exhibits/show/minstrelsy/jimcrow-to-jolson/african-american-performers., accessed 10 February 2017.

142 Michael K. Bourdaghs, p 170.

${ }^{143}$ Ibid, 178.
} 
originated forms of mass-culture Orientalism”. ${ }^{144}$ He proposes that Ri Koran was a living example of this re-created culture, representing "Japanese fantasies about the ideal Chinese woman" through "orientalist elements" such as the use of the pentatonic scale in composition, or musical instruments that imitate the traditional Chinese lute or gong. ${ }^{145}$ Similarly, in Edgar Pope's musical analysis of the features of Continental Melodies, he identifies "exotic" elements in "Soshu Yakyoku”, such as the use of a "warbling” nasal tone in the upper soprano range interspersed with delicate vibrato and melisma. ${ }^{146}$ However, this position has been challenged by scholars such as Chikako Nagayama, who questions the link between Continental Melodies and the Orientalist tradition of representing "exotic” culture. Nagayama contends that Continental Melodies stood apart from other cultural representations like American blackface performance that sought to brutally disfigure and mock black culture in a burlesque way. ${ }^{147}$

Taking into account the critical insights of Nagayama, I further argue that the Continental Melodies, as performed and embodied by Ri Koran, did not function as a parody or mockery of Chinese culture. Ri Koran's popularity with the Japanese public during the 1930s and 1940s suggests that the young star and her films and songs were anything but the subject of mockery. Following her performances of hit songs such as "When Will You Return” and "A Manchu Girl” (満洲娘 Manshu Musume) at the Greater Asia Reconstruction Exhibition (大 東亜建設博覧会 Dai toa kensetsu hakurankai) held in Hyogo, and as a member of the Imperial Song and Dance Troupe (皇軍慰問団 Kougun Imondan) to rally the soldiers at the frontline, Ri Koran was praised by Japanese media as "the splendid flower of Man'ei” and “a necessary icon of the Exhibition”. 148

In Shanghai, Ri Koran also found fame and adoration amongst her Chinese audiences.

\footnotetext{
${ }^{144}$ Michael K. Bourdaghs, “Japan’s Orient in Song and Dance”, Sino-Japanese Transculturation: From the Late Nineteenth Century to the End of the Pacific War, Lexington Books, 2012, p 27.

145 Ibid, p 168.

${ }^{146}$ Edgar W. Pope, Songs of the Empire: Continental Asia in Japanese Wartime Popular Music, Ann Arbor, Michigan: University of Michigan Press, 2003, pp. 377 - 382.

${ }^{147}$ Chikako Nagayama, “The Continental Melody - Soldiers and Japan’s Imperial Screen”, Film Music in 'Minor' National Cinemas. Bloomsbury Publishing USA, 2016, p 95. In Chikako Nagayama’s essay, she contemplates the comparison of Japanese Continental Melodies and American blackface performance that Michael Bourdaghs set up, expressing concern that "the comparison of the minstrelsy shows with the continental melody is misleading”.

148 Tairiku shinpou 大陸新報, 25 April 1940, p. 2.
} 
Ultimately she was raised to the ranks of one of the Seven Singing Stars of Shanghai (上海 七大歌星), on par with famous Chinese singers such as Zhou Xuan and Bai Hong. ${ }^{149}$ More importantly, her success in Shanghai in the early 1940s demonstrates that the target audiences of Continental Melodies were not only the Japanese public, and the cultural millieu that gave birth to this genre of music was more complex and cosmopolitan in outlook than mere Japanese propaganda.

\section{Ri Koran’s “When will You Return” - transforming a Chinese Patriot's Anthem}

“When Will You Return” was written by a patriotic Chinese song writer, Liu Xue-An, in 1936. It later became the heartfelt anthem of nationalistic Chinese living in Shanghai after the Japanese occupied the Nationalist-controlled sections of Shanghai by November 1937. This song was used in the first of Ri Koran's Continental Trilogy of Japanese National Policy films, Song of the White Orchid (1939). Interpreting the lyrics of the song (written by Huang Jia-Mo 黃嘉謨), Shen Peng-Nian explains that the words embody the tortured emotions of being a captive at the hands of the enemy and express hope for the future where “君” (pronounced as "jun” which in Mandarin means “you”) represents a return to the peace and prosperity Shanghai enjoyed prior to falling to the Japanese. ${ }^{150}$ Chao Bai explains the song's rise to fame as linked to the stifling and desperate circumstances that Shanghai now found herself in, trapped by Japanese forces. ${ }^{151}$ Singing "When Will You Return” was a way of expressing the pain of defeat and the bitterness felt by every patriotic Chinese. After the siege, this particular song would perfectly capture the melancholic sentiments of the Chinese residing in Shanghai. ${ }^{152}$ Although the song was first recorded by the Shanghai singer Zhou Xuan in 1936, ${ }^{153}$ its patriotic association came to the fore after it appeared in a short musical advertising film called Stars Moving Around the Moon (三星伴月 San Xing Ban Yue). It was sponsored by a patriotic Chinese entrepreneur, Fang Ye-Xian, who had promoted the boycott

\footnotetext{
${ }^{149}$ Ho Wai-Chung, Popular Music, Cultural Politics and Music Education in China, Routledge, 2016, p. 84. ${ }^{150}$ Shen Peng-Nian 沈鵬年, “Nianqing de qidai - Liu Xue-An de “He Ri Jun Za Lai”” 年青的期待 - 劉雪庵 的 “何日君再來” , Xingyunliushui jiwang (xia) 行雲流水記往, Shanghai sanlian chubanshe, 2011, p. 166. ${ }^{151}$ Ibid.

152 Ibid, pp 166 - 167

153 Zhang Chen-Jie 張成覺, 1957 Chinese music 中國音樂. China Independent Writers Publishing Inc, 2014, p. 173.
} 
of Japanese imports by establishing a Chinese manufacturing company in $1933 .{ }^{154}$

Largely mirroring the historical context of boycotting imports and promoting domestic merchandise, Stars Moving Around the Moon was a musical advertisement for the entrepreneur's consumer goods business. Its storyline involved the love story between Zhong Liang, whose father has founded a factory for chemical products, and the singer Wang Xiuwen. The use of mass media and entertainment to promote his business while riding the waves of Chinese nationalism was a strategy of Fang Ye-Xian. ${ }^{155}$

By singing "When Will You Return” in the National Policy film Song of the White Orchid, Ri Koran played a quintessential role in the ironic transformation of a patriotic Chinese song into a Japanese Continental Melody. Her own popularity amongst the Japanese was demonstrated by the Nichigeki Theatre riots of 1941 during which Japanese fans, who had come to watch her perform the Continental Melodies featured in her films, were so numerous that they encircled the theatre seven and a half times according to enthusiastic media reports. 156 “When Will You Return” was later recorded by Ri Koran for her 1953 album under Nippon Columbia, attesting to the lasting popularity of this song. ${ }^{157}$

\section{From Mukden to Shanghai - The Making of a Star}

Although Ri Koran is popularly perceived as a quintessential "Shanghai star," and indeed Shanghai was her cultural and spiritual home during the heyday of her career, one cannot overlook the importance of Mukden, her birthplace, in the making and shaping of her unique set of personal and cultural characteristics.

Mukden was once the capital city for the Manchus. As the symbol of the centre of political power, Mukden Palace was first commissioned by the Manchu leader Nurhaci in 1625. From the late nineteenth century, in the wake of a declining Qing Dynasty, Mukden experienced a

\footnotetext{
${ }^{154}$ Zhang Ai-Min (ed.) 張愛民 (編), “Huagong juzi fangyexian” 化工巨子方液仙, Shangjie wangshi 商界往事, Qinghua daxue chubanshe, 2012, p. 215.

${ }^{155}$ Wu Yong-Mei and Lee Pui-Tak, Graphic Images and Consumer Culture: Analysis of Modern Advertising Culture in China 圖像與商業文化：分析中国近代廣. Hong Kong University Press, 2014.

${ }^{156}$ Taiwan Yanyi - Chuanqi Geji Li Xianglan 台灣演義 - 傳奇歌姬 李香蘭, 5 October 2014. Retrieved from URL: https://www.youtube.com/watch?v=w4cW2oeorQc.

${ }^{157}$ Kokuritsu kokkai toshokan 国立国会図書館, Rekishi teki ongen 歴史的音原, “Ryukouka: Soshu Yakyoku” “流行歌：蘇州夜曲”. Retrieved from URL: http://rekion.dl.ndl.go.jp/info:ndljp/pid/3572952.
} 
tumultuous period of conflict and change, starting a long history of occupation by foreign powers. South Manchuria was the first to fall out of the hands of the Qing Dynasty. After the First Sino-Japanese War (1894-1895), as reward for playing a mediating role, Russia gained control of South Manchuria. Subsequently, they established the Southern branch of the Chinese Eastern Railway connecting Manchuria and the major cities of Mukden, Dalian, and Changchun to Vladivostok. By the end of the nineteenth century, relations between Japan and Russia were deteriorating. Japan perceived Russia to be a formidable European power.

However, they did not stop seeking opportunities to expand their territory. The last and most decisive battle of the war, known as the Battle of Mukden, proved to be a turning point for the Japanese. Following their victory over Russia, Japan gained control of this crucial railroad South of Changchun (Shinkin during the existence of the Manchukuo state), renaming it the South Manchurian Railway (南滿洲鐵道 Minamimanshu Testudo) and establishing a holding company named the South Manchurian Railway Company (南満洲鐵 道株式會社 Minamimanshu Tetsudo Kabushikigaisha). ${ }^{158}$

Mukden, therefore, had its own multicultural ecosystem. As one of the biggest and most populated cities in Manchuria, it was positioned on the border with Russia and witnessed the Russo-Japanese War between 1904 and 1905, as well as the Russian Revolution of 1917. Later on, it even became a shelter for many Russian exiles. Mukden's historical and cultural fabric can be perceived as jointly woven over centuries by the Manchus, the Mongolians, the Koreans, and the Chinese, while the Japanese and Russians can be seen metaphorically as her adopted children. Evidence of Japanese and Russian influence nowadays is still easy to find. It is not difficult to locate the lasting influence of the Russian Orthodox tradition in the form of memorial chapels and churches, and Showa-style Japanese architecture exemplified by the Mukden train station.

In 1920, Yamaguchi Yoshiko was born into a newly-migrated Japanese family in Mukden, Manchuria. She was the first-born child of Fumio Yamaguchi, a Chinese language teacher working for the South Manchurian Railway Company. This is where she was given her wellknown Chinese name, “Li Xiang-Lan” (李香蘭), by her Chinese godfather General Li Ji-

\footnotetext{
${ }^{158}$ Henry Walsworth Kinney, Modern Manchuria and the South Manchurian Railway Company. Japan Advertiser Press, 1928, p. 31.
} 
Chun ${ }^{159}$ and where she started to learn Mandarin. Here she met her best friend, the Russian girl Lyuba Monosova Gurinets, who enthusiastically introduced Ri Koran to a prominent opera singer named Madame Podresov for singing lessons to help her with her posttuberculosis breathing problems. ${ }^{160}$

Ri Koran was born and raised in this peculiar land of rich history. Mukden was the root of her cosmopolitan nature. When she started to perform traditional Chinese songs in standard Mandarin with a Peking accent, combined with her Russian-influenced vocal technique and style, she created a unique new experience that was rarely heard in Chinese music. Ri Koran’s circumstances shaped her into the ideal representation of "Hakko Ichiu” ideology, which in Manchuria was reiterated through the concepts of “Niman Shinzen” (日満親善 JapanManchuria Goodwill) and “Gozoku Kyowa” (五族協和 Ethnic harmony among the Five Races). Ri Koran was first scouted by the Mukden Broadcasting Company as a child-singer to perform on the celebration of Manchukuo's establishment in $1932 .{ }^{161}$ This monumental event marked her starting point as a propaganda vessel for Japanese imperialism.

How did the Mukden-born star transition to Shanghai, the newly-established international city, and how did Japanese imperialist ideology reconcile with Chinese cosmopolitanism? As a treaty port first under the Treaty of Nanking of 1842 and subsequently under various other unequal treaties signed by China with Western powers, Shanghai became a free port where travellers could enter without passports. ${ }^{162}$ By 1930, Shanghai had developed into the fifth largest city in the world and was "fabulously cosmopolitan". ${ }^{163}$ Shanghai's unique situation of international concessions and its great cosmopolitan melting pot of people and culture helped to shape its music.

Western musical influences in the form of musicians and musical instruments were

\footnotetext{
${ }^{159}$ Yamaguchi Yoshiko 山口淑子, Chen Peng Ren (trans.) 陳鵬仁 (譯), Li Xianglan zijuan: Zhanzhen, heping $y u$ ge 李香蘭自傳：戰爭、和平與歌. Taiwan shangwu, 2004, p. 227.

160 "Looking back on my days as Ri Koran," The Asia-Pacific Journal 2(10), Oct 11 2004. Retrieved from URL: http://apjjf.org/-Onuma-Yasuaki--Utsumi-Aiko--Tanaka-Hiroshi/1571/article.pdf., accessed 23 February 2017. ${ }_{161}$ Peter B. High, The Imperial Screen: Japanese Film Culture in the Fifteen Years' War 1931-1945, University of Wisconsin Press, 2003, p. 272.

${ }^{162}$ Charlotte Ku, Abolition of China's Unequal Treaties and the Search for Regional Stability in Asia, 1919-1943, 12 Chinese (Taiwan) Y.B Int'l L. \& Aff., 1994, pp. 67 - 69.

${ }^{163}$ D. Slaymaker, "Shanghai three ways - The 1930s view from Tokyo, Paris and Shanghai", Foreigners and Foreign Institutions in Republican China. Routledge, 2013, p 131.
} 
introduced by European immigrants. The Shanghai Municipal Orchestra (上海工部局樂隊 Shanghai gongbuju yuedui), which had its origins in the Shanghai Municipal Band created in 1879, absorbed many of these migrant European musicians, many of whom had fled to Shanghai to escape revolution. ${ }^{164}$ The 1917 Russian Revolution had brought Russian émigrés such as the "white" counter-revolutionaries fleeing to the free port of Shanghai. ${ }^{165}$ This particular group of white Russian diaspora was comprised of world-class musicians and composers. ${ }^{166}$

Shanghai was also developing a name for itself as the cradle of modern Chinese music. Xiao You-Mei, one of the founders of China's first formal institutions of music, the National Conservatory of Music (国立音楽院 Guoli yinyue yuan), was himself educated abroad at the Tokyo Imperial University and at the Leipzig Hochschule für Musik und Theater. He was open to introducing a wide range of musical instruments and hiring a legion of foreign musicians as lecturers. Many Chinese composers at the time, such as Liu Xue-An who composed “When Will You Return” benefitted from this Western-influenced music education as graduates of the institution.

It was in this broad environment that Ri Koran began to build her entertainment career in Shanghai. In the late 1930s and early 1940s, a series of Shanghai-related productions ensued. She released the song "Saraba Shanghai" in 1939, followed by the film China Nights in 1940 which took Shanghai as its setting. In December of that same year, Man'ei made a significant investment by acquiring a 25 percent stake in the Shanghai-based film company Zhonghua Dianying Gufen Youxian Gongsi (中華電影股份有限公司, or 中影 Zhongying for short) alongside the Reorganised National Government led by Wang Jing-Wei. ${ }^{167}$ Zhongying had been established in June 1939 to serve the Japanese imperialist cause as a National Policy company, like Man'ei, in support of the Nanking government's political goals of “Anti-

\footnotetext{
${ }^{164}$ E. F. Harris, “The Story of the Municipal Orchestra”, Souvenir Programme of Farewell Concert, Shanghai Municipal Orchestra, May 31(5), 1942.

165 Donald J. Raleigh, Experiencing Russia's Civil War - Politics, Society and Revolutionary Culture in Saratov, 1917 - 1922, Princeton University Press, 2002, pp. 1 - 11.

${ }^{166}$ Donald J. Raleigh, Experiencing Russia's Civil War - Politics, Society and Revolutionary Culture in Saratov, 1917 - 1922, Princeton University Press, 2002, pp. 1 - 11.

${ }^{167}$ Goto Noriko 後藤典子, Nippon senryoka ni okeru Shanghai eiga to Nanking kokumin seifu no eigasangyo seisaku, bunkaseisaku nit suite 日本占領下における上海映画と南京国民政府の映画産業 政策、文化政策 につい, Ochanomizu University, 2011, p. 72.
} 
communism, Peace and Nation-building” (平和, 反共, 建國 Heping, Fangong, Jianguo). ${ }^{168}$ By acquiring a stake in the Shanghai-based film company, Man'ei was effectively paving the way for Ri Koran to break into the Shanghai entertainment world by using Zhongying as a platform.

In Shanghai, Ri Koran's singing career also took flight. In the initial stage of her career as a singer, she had recorded songs with the Manchurian-based music recording company Baile (百樂), including “When Will You Return”. By 1940, she had expanded beyond Manchuria and began to record songs with Nippon Columbia (from May 1927, called Nippon Chikuon ${ }^{169}$ ). Ri Koran's bilingual ability helped her to sustain her singing and acting career in Shanghai, allowing her to blossom in the multicultural context of the city. Her enigmatic Chinese image was embraced by cosmopolitan Shanghai while her European vocal technique was quickly accepted by the Chinese mainstream.

\section{Hattori Ryoichi and his Continental Melodies - Tailoring for Ri Koran's Success}

Meanwhile, Shanghai and its music scene would make an impact on another key figure of Continental Melodies - the Japanese composer Hattori Ryoichi (服部良一). Hattori travelled to China for the first time in 1938 as a saxophonist with the Central China Song and Dance troupe (中支慰問団 chushi imondan), a special brigade of performers organised by the Tokyo Nichi Nichi Newspaper and sponsored by the Japanese army to entertain Japanese troops on the ground. ${ }^{170}$ The music he experienced in Shanghai, which he had longed to visit for its musical reputation, would have a lasting and significant influence on his music. Hattori became one of the key composers of Continental Melodies, writing various melodies featured in National Policy films during the war. These included “Itoshi ano Hoshi” (いとしあの星) in Song of the White Orchid and "Soshu Yakyoku" in China Nights.

\footnotetext{
168 Zhao Ming-Zhong 趙銘忠 (ed), Wangweizhengfu xingzhengyuan huiyilu/zhongguo dier lishidangagguan bian 汪偽政府行政院會議録 / 中國第二歴史档案館編, Dangan chubanshe档案出版社, 1992, pp. 2-426. ${ }^{169}$ Hiroshima Keizai Daigaku keizai kenkyuron 30(1-2), 日本レコード産業の生成期の牽引車=日本蓄音 器商会の特質と役割 Nippon recodo sangyo no seisenki no keninsha = nipponchikuonki shokai no tokushitsu to yakuwari, October 2007, p. 13.

170 James Farrer and Andrew David Field, Shanghai Nightscapes: A Nocturnal Biography of a Global City, University of Chicago Press, 2015, p 129.
} 
Hattori's Continental Melodies fit National Policy films well and were successful. They became popular songs for the Japanese public and were also well-regarded by contemporary Chinese composers in Shanghai such as Li Jin-Hui and Chen Ge-Xin. ${ }^{171}$ The success of Hattori's Continental Melodies is also reflected in Ri Koran's commercial success in both Japanese and Chinese markets through performing these songs in her Continental Trilogy. An outstanding example is the Nichigeki riots of 1941 which were sparked by swarming Japanese fans eager to watch Ri Koran perform songs from the Continental Trilogy of films. ${ }^{172}$ Hattori's tunes such as “Soshu Yakyoku” and the much-loved “Yelaixiang” (夜來香 Evening Primrose) were so popular that they played a significant role in boosting Ri Koran's singing career in Shanghai, contributing to her iconic status as one of the Seven Great Singing Stars.

Japanese attraction to Hattori's Continental Melodies can be attributed to the multicultural blend of musical elements found in his music. Hattori had been inspired to create a blended form of music by his experience with Chinese popular music in Shanghai through the likes of Li Jin-Hui. In Hattori's recounting of time spent in China, he made an important observation that contemporary Chinese composers in Shanghai were creating a unique blend of fusion music that assimilated Chinese folk music with European jazz. ${ }^{173}$ This was a significant revelation for Hattori, who acknowledged Shanghai to be the true home of jazz in Asia ${ }^{174}$ and who was motivated to compose music inspired by his experience in China. The most notable outcome of this experience was "Soshu Yakyoku”. The song opens with a whining violin mimicking the voice of a Chinese erhu, creating a "strange cocktail of East and West" that became Hattori's signature style. ${ }^{175}$ For Japanese audiences, the experience of Hattori’s music was a new and exciting form of entertainment that was in sync with the increasingly cosmopolitan environment created by Japan’s imperialist exploits in Manchuria and China.

\footnotetext{
${ }^{171}$ Yasuko Enamoto 泰子榎本, “Chugoku ongakushi kara kieta ryokoka - Mou hitotsu no 'Ye Rai Xiang Rhapsody” 中国音楽史から消えた流行歌 - もう一つの「夜来香ラプソデイー, Toyoshi kenkyu東洋史 研究 69(3), 2010, Kyoto University, pp 467 - 68.

172 Taiwan Yanyi - Chuanqi Geji Li Xianglan 台灣演義 - 傳奇歌姬 李香蘭, 5 October 2014. Retrieved from URL: https://www.youtube.com/watch?v=w4cW2oeorQc.

${ }^{173}$ Ueda Kenichi 上田賢一, Shanghai Boogie Woogie 1945 Hattori Ryoichi no bouken 上海ブギウギ 1945 服 部良一の冒険, Ongaku no tomosha kan 音楽之友社刊, 2003, p 19.

${ }^{174}$ Yasuko Enamoto 泰子榎本, p 481.

175 James Farrer and Andrew David Field, Shanghai Nightscapes: A Nocturnal Biography of a Global City. University of Chicago Press, 2015, p. 130.
} 
On the other hand, Hattori's music contained many Chinese musical characteristics, such as the use of the pentatonic scale in composition and the recreation of the sound of traditional Chinese instruments through the clever use of Western instruments. To Chinese audiences, Hattori's music would have struck a chord of intimacy, ultimately leading to the creation of the Mandarin version of “Soshu Yakyoku” by Bai Hong in 1943.

Ri Koran's transformation of "When Will You Return” from a patriotic Chinese song into a Continental Melody and Hattori's success with "Soshu Yakyoku” which crossed over multiple cultural and linguistic boundaries, provide ample evidence that Continental Melodies was not an Orientalist form of "counterfeit” culture. As demonstrated earlier in this chapter, there are significant differences between the Orientalist tradition and the nature of Continental Melodies. In Hattori's case, interpreting his music as containing the Orientalist overlays of imitation is at odds with his intimate relationship with Shanghai culture and contemporary Chinese music during the war years. ${ }^{176}$

Hattori greatly admired Chinese popular music and credited Shanghai not just for the birth of the Continental Melody “Soshu Yakyoku”, but also the birth of his Japanese hit song, “ Tokyo Boogie Woogie.” ${ }^{177}$ His Continental Melodies, a by-product of Sino-Japanese cultural realtions during wartime Shanghai, ultimately served a powerful propaganda function. The ability of this cultural product to win over both Japanese and Chinese audiences was fueled by Japanese military power and served Japanese imperialist ideology, but we cannot overlook the elements of love and respect for Chinese culture in these compositions or deny their ties with Shanghai's cosmopolitan culture at the time. The same can be said about Ri Koran's role as an actress and a singer. On the one hand, her bilingual and multicultural make-up made her the perfect propaganda instrument of Japanese imperialism; on the other hand, those same qualities made her a pin-up girl for Shanghai cosmopolitanism as one of its Seven Stars.

\footnotetext{
${ }^{176}$ Yasuko Enamoto 泰子榎本, “Chugoku ongakushi kara kieta ryokoka - Mou hitotsu no 'Ye Rai Xiang Rhapsody””中国音楽史から消えた流行歌 - もう一つの「夜来香ラプソデイー」, Toyoshi kenkyu東洋 史研究 69(3), 2010, Kyoto University, p. 469. Hattori's music was respected and loved by contemporary Chinese composers in Shanghai such as Chen Ge-Xin who were eager to seek his tutelage in the art of composition.

177 Ueda Kenichi 上田賢一, Shanghai Boogie Woogie 1945 Hattori Ryoichi no bouken 上海ブギウギ 1945 服 部良一の冒険, Ongaku no tomosha kan, 2003, p. 14.
} 


\section{The Resonance of Lyrics}

The fame and popularity of "Soshu Yakyoku”'s melody helped Hattori establish a solid reputation in the Japanese music world. Yet the lyrics accompanying the melody, written by Saijo Yaso, have received little critical or scholarly attention. The lyrics of "Soshu Yakyoku" function as the second belated but nevertheless valuable preface to the film China Nights. Its words offer an alternative imaginativeness that thickens the relationship between Keiran and Hase, and reminds the audience how Ri Koran, who sings "Soshu Yakyoku” in the film as Keiran, is the embodiment of "Hakko Ichiu". By combining the poetic lyrics of this song with her own exquisite singing voice, Ri Koran ensures that China Nights is remembered not just for its romantic narrative, but also for its music, thereby extending the film's influence beyond the sphere of cinema. I begin with the observation that the words and phrases of Saijo's lyrics were carefully selected and arranged into a compendium of emotions, settings, and characters that resonate powerfully with the film China Nights.

The lyrics written by Saijo are as follows, accompanied by English translation:

君がみ胸に 抱かれて闻くは 夢の船呗 鳥の歌 水の蘇州

の 花散る春を 惜しむか

柳がすすり泣く 花を浮かべ

て 流れる水の 髪にか飾ろ

か 接吻しよか 君が手折し

桃の花 涙ぐむよなおぼろ

の月に 钟が鸣ります寒山寺

In your embrace

Dreamily I listen to the chanty and birdsong

As the blossoms scatter along water-like Suzhou during spring

It's such a pity

Willows gently weep

Floating flowers on a running river 
Should I use the peach blossoms you picked to decorate my hair or should I offer a kiss The blurry moon seems very tearful Just now, the bell tolls in Hanshan Temple.

[Original Translation for the purposes of this thesis]

Saijo Yaso was a poet and literary figure who graduated from Waseda University (早稲田大 学) in French literature and made the acquaintance of other Japanese literary greats including Natsume Soseki (夏目漱石), with whom Saijo organised a journal called The Holy Chalice ( 聖盃). ${ }^{178}$ In an interview with TV Asahi, the lyricist of the original Japanese version Saijo Yaso spoke of applying “goshichicho" (五七調) to writing poetry ${ }^{179}$, that is, alternating between five and seven syllables in a set of coupled phrases.

The opening Japanese lyrics offer listeners a beautiful scenario replete with images of boats, flowers, birds, and the canals of Suzhou. Saijo’s first sentence “君がみ胸に” (Kimi ga mune ni) confirms that this poem was written by a male poet by addressing the second-person personal pronoun singular “you” in “君” (kimi). Between the two songs “When Will You Return” (何日君再來 He Ri Jun Zai Lai) and “Soshu Yakyoku,” there is a striking similarity in the use of the second-person pronoun “君” (kimi in Japanese and jun in Chinese). The original Japanese lyrics of “Soshu Yakyoku” start with “君” (kimi), a very common masculine second-person pronoun. By using such word-play as the threshold of true love, Saijo sets out the lyrics' subject, aims, and means and seeks to capture the audience's emotions along the way. This singular pronoun functions as prefatory material for interconnecting the song, through which the audience can gather their sentiments from the preamble before being ushered into the whole set of lyrics. Through direct address in the opening sentence of the lyrics, Saijo constructively confirms to each individual member of the audience that the love

\footnotetext{
178 The Holy Chalice commenced publication in 1912 with a focus on poetry. Natsume Souseki, Saijo Yaso, and various others contributed their poetry to this journal. Retrieved from URL:

https://kotobank.jp/word/\%E6\%97\%A5\%E5\%A4\%8F\%E8\%80\%BF\%E4\%B9\%8B\%E4\%BB\%8B120468., accessed 3 March 2017.

${ }^{179}$ Saijo Yaso discussed poetry writing in a Nippon Hoso Kyokai (NHK) programme entitled Ano hito ni aitai あ の人に会いたい. Retrieved fromURL:

https://www2.nhk.or.jp/archives/jinbutsu/detail.cgi?das_id=D001601005600000., accessed 20 March 2017.
} 
story has begun.

Verbs have been used in various places of the lyrics to reflect the cogitations and actions in the film scenes. This is evident in the lines:

髪にか飾ろか 接吻しょか

Should I use the peach blossoms you picked to decorate my hair or should I offer a kiss

Keiran demonstrates her willingness to accept Hase and Japan as a whole with this lyric. In the film, she contemplates two types of actions in anticipation of the peach blossoms that Hase is going to give her. One is to decorate her hair with these flowers, the other to offer a kiss. The acceptance of Hase's peach blossoms and the intention of decorating her hair with these flowers symbolises her recognition of her newly established admiration for the Japanese who were once her enemy. She would proudly and openly announce this new-found happiness of hers to the world by adorning her hair prominently with these flowers. As a second option, she offers a kiss. This is much more intimate than the first option and emphasizes the inauguration of a personal bond between Keiran and Hase, as China and Japan. The film uses the lyrics of "Soshu Yakyoku" to prophesy happiness for the Chinese under the imperialist ideology of "Hakko Ichiu”.

In the context of the film, alongside the melody, the lyrics corresponded with the movement of film scenes such as Hase’s picking of peach blossoms (君が手折し 桃の花) (Figure 20) and the lovebirds listening to the pealing of the bell of Hanshan Temple （钟が鸣ります 寒山寺) while standing somewhere in the vicinity of the temple (Figure 21).

While the audience is listening to the song, the visual images vary as analogous to the singing description of Suzhou's scenery. 
This content is unavailable.

Please consult the print version for access.

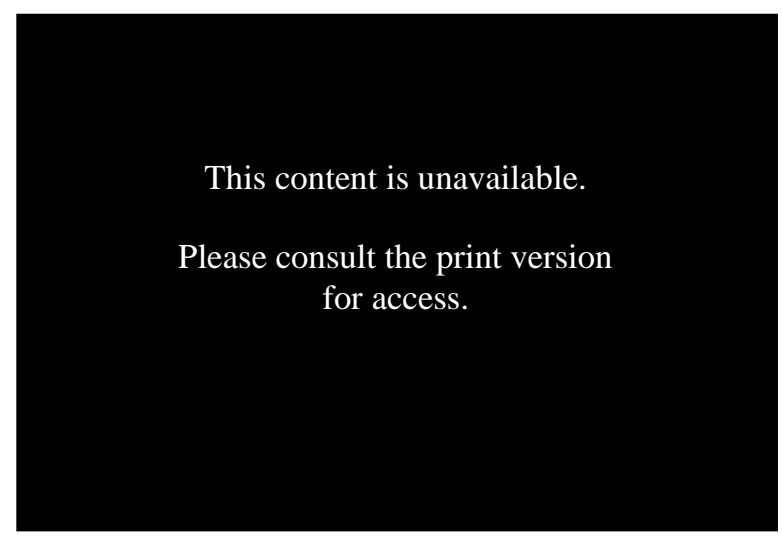

Figure 21 Listening to the Hanshan Temple

Figure 20 Hase picking peach blossoms bell

This calibrated cinematic technique was exceedingly mindful, yet surprisingly calculated. Ri Koran utilised her vocal technique to draw the audience's attention to the peaceful Suzhou scenery and Keiran's joyful presence. The ideal world that imperial Japan was presenting was ironically different from the cruel and ferocious reality it had created.

Another interesting element in the lyrics is the choice of season and choice of flowers. “桃の 花” (peach blossoms) represented romance between a man and a woman, and contained numerous positive symbols in Chinese culture. The poet Tao Yuan-Ming’s (陶淵明 365-427) renowned poem “The Peach Blossom Spring” (桃花源記 Taohuayuan Ji) describes the chance discovery of a utopian land of peach blossoms that symbolises a highly sought after heavenly place of peace and simplicity. ${ }^{180}$ This is a place where one could seek refuge from the turmoil of war and live in ultimate happiness. ${ }^{181}$ The underlying suggestion that for Keiran, the only way to achieve real happiness is to be with Hase. Through the application of this commonlyknown classical poem, the film cleverly educates both the Chinese and Japanese audiences. Ri Koran was filmed singing "Soshu Yakyoku” in a famous peach blossom garden called “ 桃花塢” (Taohua Wu) located in the “姑蘇” (Gusu) district of Suzhou. This deliberate setting is a clever reference to Tang Dynasty poet Zhang Ji’s (張繼) famous poem “A Night Mooring

\footnotetext{
180 The referenced lines from Tao Yuan-Ming (陶淵明)'s poem “The Peach Blossom Spring” (桃花源記 Taohuayuan Ji) are “忽逢桃花林，夾岸數百步，中無雜樹，芳草鮮美，落英繽紛” (Hufeng taohualin, jia'an shubaibu, zhongwu zashu, fangchao xianmei, luoying bingfen).

${ }^{181}$ Wang Xiao Lin 王小林, Nichu hikaku shinwagaku 日中比較神話学, kyukoshoin 汲古書院, January 2014, pp 172-173.
} 
by Maple Bridge” (楓橋夜泊 Fengqiao yebo). In his poem, the protagonist hears the pealing of the bell of Hanshan Temple close by, just outside Gusu district. ${ }^{182}$ Similarly in the film, Hase and Keiran are located close to Hanshan Temple, in the peach blossom garden of Gusu district. The purpose of this literary reference is to legitimise the authenticity of the film in terms of its reflection of China.

The singing of lyrics can therefore be seen to largely mirror the narrative of the film. After receiving the terrible news of Hase's alleged death, Keiran revisits the places in Suzhou she had been to previously with Hase, mourning the loss of her beloved. To match her lonely sojourn, Ri Koran as Keiran begins to sing three melancholic lines from Saijo’s lyrics:

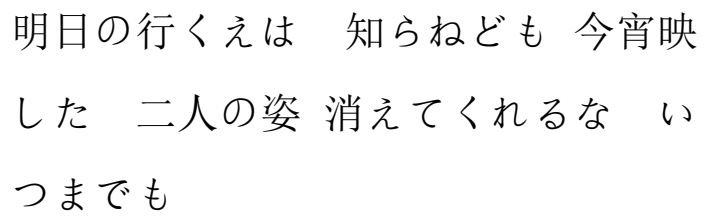

Probably no one knows where they will be tomorrow

Tonight this reflection of both of us

May they never ever disappear

The lyrics deliver the tragic denial of a hopeful prayer by lovers. By singing these lines, Ri Koran gives full expression to the grief of losing a loved one such that the audience understands her pain both on a visual level through scenes from the film and on an audio level through a Continental Melody. Notably, these three lines were absent from Ri Koran's performance of "Soshu Yakyoku" earlier in the film when Hase and Keiran were depicted strolling through Suzhou's landmark sites, basking in each other's company. The melancholy evoked by these lyrics would not have been coherent with the happiness Keiran was experiencing at that point in the film. The concluding line brings the audience back to the moment in the film when we actually heard the chime of a gong. This happened near the start of Hase and Keiran's sojourn in Suzhou, when they stood close to each other, admiring the surrounding scenery (Figure 21).

\footnotetext{
${ }^{182}$ The referenced lines from Zhang Ji (張繼)'s poem “A Night Mooring by Maple Bridge” (楓橋夜泊) are “姑 蘇 城外寒山寺, 夜半鐘聲到客船”(Gusuchengwai hanshanshi, yeban zhongshen daokechuan).
} 
“Soshu Yakyoku” was created with great care and effort. It contains many cultural references and was a living demonstration of Suzhou and China to the general Japanese public. The visual attraction of the carefully selected scenery combined with the deliberately designed love storyline maximised the power of persuasion to liberate China from its past. Although many of the Chinese public may not have seen the film, Japanese-educated intellectuals who lived in Shanghai would likely not have missed this song. The vinyl records industry was flourishing and phonographs were ubiquitous in Shanghai, and thanks to commercial goods such as radios, Ri Koran's songs had many more channels to penetrate deeply into the minds of the target audience.

An instrumental version of "Soshu Yakyoku" plays gently in the background as accompaniment. Keiran laments that she never imagined that the happiness she was experiencing could ever exist in this world and, as her voice falters, a bell chimes somewhere in the vicinity. Such unimaginable happiness can only come by letting go of the past and accepting the Japanese as family. Ri Koran's performance delivered a very powerful but hallucinatory message on the ideal state of Sino-Japanese relations. Yet one cannot be persuaded that ultimate happiness can only be secured by sacrificing tens of thousands of lives on the battlefield.

Continental Melodies was a genre of popular music created during the war years and customised particularly for Japanese war propaganda. It arose out of a need to deliver propaganda messages to the Japanese general public. In the guise of entertainment, music was the perfect accompaniment to National Policy films which were designed to distort the reality of war and consequently, to disguise Japan's war atrocities. While film acted as a visual programme of propaganda to create the impression of Japanese righteousness in its actions of war and the mirage of romance between Japan and China, Continental Melodies served as the audio programme that reiterated the films’ messages through their memorable tunes, sweet vocals, and tender emotions of romantic love that the songs describe and evoke in the audience. Essentially, for those who watched Ri Koran’s Continental Trilogy of National Policy films, Continental Melodies such as “Soshu Yakyoku” enabled the films' narratives and propaganda messages to be "re-lived" each time the melodies were played.

This phenomena can happen in the absence of film because of the highly evocative nature of 
song lyrics and the close association between lyrics and film as demonstrated in the earlier analysis of "Soshu Yakyoku”. Ri Koran excelled in becoming a living embodiment of "Hakko Ichiu" through both body and voice. Her success in Mukden and Shanghai revealed the complex dynamics of cultural, commercial, political, and military forces during the war. 


\section{Conclusion}

\section{Ri Koran/Li Xianglan: Icon of Japan’s Imperial Unifying Ideology}

Ri Koran was a carefully crafted embodiment of "Hakko Ichiu", an ideology that combines classical Chinese literary reference and Buddhist tenets, nurtured and promoted by the propaganda machine that was the Manchurian Film Association. Her unique set of attributes - her birth, upbringing, bilingualism, physical beauty, and operatic training - enabled her to become the ultimate representation of Japanese National Policy films, both in image and voice. Her presence on the silver screen functioned as a mirage to entice audiences to embrace the concept of a Greater East Asia Co-Prosperity Sphere under Japan's leadership in a symbolic act of bringing the world under one roof.

Ri Koran’s Continental Trilogy served as more than just entertainment but subtly educated the audience regarding the illusory benefits of “Hakko Ichiu.” In these propaganda films, Ri Koran often portrayed a hot-headed and ill-mannered Chinese woman who could nevertheless be "tamed" with the appropriate guidance from a morally upright Japanese society. In China Nights, her rough and ungracious character, Keiran, initially detested Japan and its people. Despite her initial hostility towards the Japanese, the film concludes with a fairy tale happy ending in which Keiran the Chinese girl, who resisted Japanese goodwill at the outset, is eventually touched and enlightened by her Japanese admirer.

The success of converting the unruly Chinese girl into a dutiful member of a Japanese household delivers a promising prophesy for the future of Sino-Japanese relations. Using Ri Koran's performance to symbolise China's process of conversion from hatred to love, the film advocates the ideology of "Hakko Ichiu" through familiar concepts such as family and marriage. However, contrasts between scenes and messages from the film, and historical war footage reveal distinct differences that demonstrate the glaring gap between historical truth and visual representation. 
The gap between history and its representation is further highlighted through analysis of the musical elements of the film. One of the key features of China Nights was its Continental Melodies. This genre of music was created to accompany National Policy films, to complement their propaganda messages. The music also extended the visual elements of the film, functioning as an additional mode of propaganda for spreading the ideology of "Hakko Ichiu". As demonstrated in the case study of "Soshu Yakyoku" from the perspectives of melody and lyrics, through the integration of popular Chinese music elements from cosmopolitan Shanghai with carefully-presented classical Chinese poetry elements, music enabled Ri Koran to border-cross from Manchuria to Shanghai, and from imperialist propaganda to popular entertainment. Her enchanting voice, while instrumental to the effectiveness of Continental Melodies' propagandistic role, was also key to her success in the entertainment industry of cosmopolitan Shanghai. 


\section{References Cited}

“African American Minstrel Performers”, an exhibition on the History of Minstrelsy. Retrieved from URL: http://exhibits.lib.usf.edu/exhibits/show/minstrelsy/jimcrow-to-jolson/africanamerican-performers.

Anderson, Joseph I, Joseph L. Anderson and Donald Richie, The Japanese Film: Art and Industry, rev. ed. Princeton University Press, 1982

Ano hito ni aitai あの人に会いたい, NHK programme.

Retrieved from URL:

https://www2.nhk.or.jp/archives/jinbutsu/detail.cgi?das_id=D0016010056_00000.

Asahi Shimbun 朝日新聞, 1940 (June 9), “Shin eigahyo” 新映画評.

Aston, W. G. (trans.), Nihongi. 2 vols, London, 1956.

Boeicho boeikenshusho senshishitsu 防衛庁防衛研修所戦史室 Shinajihen rikugunsakusen 支那事变陸軍作戦, Asagumo shinbunsha 朝雲新聞社, 1976.

Bolt, Robert, A Man for All Seasons, Globe Theatre premiere, 1 July 1960.

Botstein, Leon, “Classical music: Why music in a time of war?” The New York Times, March 3, 1991.

Brittanica kokusai daihakka jiten ブリタ二カ国際大百科事典. Retrieved from URL: https://kotobank.jp/word/\%E7\%8E\%8B\%E9\%81\%93\%E3\%83\%BB\%E8\%A6\%87\%E9\%81

\%93-38820.

Brook, Timothy, Collaboration: Japanese Agents and Local Elites in Wartime China, Cambridge, MA: Harvard University Press, 2007. 
Brown, Roger, “Konoe Cabinet’s ‘Declaration of a New Order in East Asia,' 1938,” in Sven Saaler and Christopher W.A.Szpilman (eds), Pan-Asianism: A Documentary History, 1920Present, Rowman \& Littlefield Publishers, 2011.

Cao Xue-Qin 曹雪芹, Dream of the Red Chamber 紅樓夢.

Chambers, John Whiteclay and David Cuthbert, World War II, Film and History, Oxford University Press, 1996.

Chen Zhen Ling and Long Deng Gao 陳爭平, 龍燈, “Ri jun zhan qu de zhimindi jingji” in Zhong guo jingdai jingjishi jiaocheng “日軍占區的殖民地經濟” , 中國近代經濟史教程, Qing hua da xue chu ban she you xian gong si 清華大學出版社有限公司, 2012.

Coates, Jennifer, Making Icons: Repetition and the Female Image in Japanese Cinema, 1945 -1964, Hong Kong University Press, 2016.

Crawford, James, The Creation of States in International Law, Oxford University Press, 2006. Davies, Peter, Dangerous Liaisons: Collaboration and World War Two, Routledge, 2014.

Dr Sun Yat-sen Academic Research Site 孫中山學術研究資訊網, Minzu Zhuyi 民族主義. Retrieved from URL: http://sun.yatsen.gov.tw/content.php?cid=S01_03_03_01.

Edwards, Walter, “Forging Tradition for a Holy War: The 'Hakko Ichiu' Tower in Miyazaki and Japanese wartime ideology,” The Journal of Japanese Studies 29(2) (Summer 2003).

Eizawa Koji, Daito-A kyoeiken no shiso, Tokyo: Kodansha, 1995.

Enamoto, Yasuko 泰子榎本, “Chugoku ongakushi kara kieta ryokoka - Mou hitotsu no 'Ye Rai Xiang Rhapsody;”’”国音楽史から消えた流行歌 - もう一つの「夜来香ラプソデ イ一, Toyoshi kenkyu 東洋史研究 69(3), 2010, Kyoto University.

Fairbank, John King and Denis Twitchet (eds.), The Cambridge History of China, Cambridge University Press, 1978.

Farrer, James and Andrew David Field, Shanghai Nightscapes: A Nocturnal Biography of a 
Global City, University of Chicago Press, 2015.

Fouraker, Lawrence, “Saito Takao and Parliamentary Politics in 1930s Japan”, Sino-Japanese Studies 12(2), April 2000.

Franklin D. Roosevelt Address at Chicago on October 5 1937. Retrieved from URL: http://millercenter.org/president/speeches/speech-3310.

Frankopan, Peter, The Silk Roads: A New History of the World, Bloomsbury Publishing, 2015. Furukawa Takahisa 古川隆久, “Sensoushita no nippon eiga - hitobito wa kokusakueiga wo mitaka”戦時下の日本映画 人々は国策映画を見たか,Yoshikawa koubunkan 129.

Gao You 高誘, Huai Nan Hong Lie Jie Xu 淮南鸿烈解序.

Gauntlet, John Owen (trans.), Kokutai no Hongi: Cardinal Principles of the National Entity of Japan. Cambridge, Mass: Harvard University Press, 1949.

Gerth, Karl, China Made: Consumer Culture and the Creation of the Nation, Harvard University Asia Centre, 2003.

Ginoza, Naomi, "Dissonance to Affinity: An ideological analysis of Japanese Cinema in the 1930s.” PhD Dissertation, UMI, 2007.

Godart, Clinton, “Nichirenism, Utopianism, and Modernity - Rethinking Ishiwara Kanji’s East Asia League Movement,” Japanese Journal of Religious Studies 42(2), Nanzan Institute of Religion and Culture, 2005。

Goto Noriko 後藤典子, Nippon senryoka ni okeru Shanghai eiga to Nanking kokumin seifu no eigasangyo seisaku, bunkaseisaku nitsuite 日本占領下における上海映画と南京国民政 府 の映画産業 政策、文化政策について, Ochanomizu University, 2011.

Guo Yu-Wen 郭玉雯，“Hongloumeng” Yuanyuanlun: Cong shenhua dao mingqing sixiang 《紅樓夢》淵源論: 從神話到明清思想, Guoli Taiwan daxue chubanzhongxing, 2006.

Habito, Ruben, “The Uses of Nichiren in Modern Japanese History,” Japanese Journal of 
Religious Studies 26(3/4) (Fall 1999).

Hall, B.E. Foster, The Chinese Maritime Customs: An International Service, 1854 - 1950, Occasional Papers No. 5., as part of The Chinese Maritime Customs Project, UK, University of Bristol, 2015 (reproduction of original from 1977).

Hans van Ven, China at War: Triumph and Tragedy in the Emergence of the New China 1937 - 1952, Profile Books, 2017.

Hanyu Dacidian 漢語大詞典. Retrieved from URL:

http://cidian.wenku1.com/zhuanti/\%E5\%BD\%A2\%E5\%AE\%B9\%E5\%81\%B6\%E5\%83\%8F \%E7\%9A\%84\%E8\%AF\%8D\%E8\%AF\%AD.html.

Harmsen, Peter, blog on China in World War II, with comments on 22 July 2013 on "Media War Over.” Retrieved from URL: http://www.shanghai1937.com/media-war-over-shanghai/.

Harris, E. F., "The Story of the Municipal Orchestra," Souvenir Programme of Farewell Concert, Shanghai Municipal Orchestra, May 31(5), 1942.

Henry Walsworth Kinney, Modern Manchuria and the South Manchurian Railway Company, Japan Advertiser Press, 1928.

He Zhi Hua 何志華, Tang Song Lei Shu 唐宋類書徵引《淮南子》資料彙編, Chinese University Press, 2005.

Heiwa no To no Shijitsu wo Kangaeru Kai, Ishi no Shogen, Miyazaki-ken Higashi Morokatagun Takaoka -cho: Honda Kikaku, 1985.

Hibbert Clyde, Paul and Burton F. Beers, The Far East: a history of the Western impact and the Eastern response (1830-1970), Prentice-Hall, 1971.

Hideo Kobayashi 英夫小林, “Toa renmei undo: Sono tenkai to higashi ajia no nashionarizumu” “東亜連盟運動一その展開と東アジアのナショナリズム” Teikoku to iu genso: Daitoakyoeiken no shiso to genjitsu 帝国という幻想、大東亜共栄圏の思想と現実, Tokyo: Aoiki Shoten, 1998.

High, Peter B, The Imperial Screen: Japanese Film Culture in the Fifteen Years’ War 1931 - 
1945, University of Wisconsin Press, 2003.

Hirata Yuji, “Kenetsu no madokara nippon eigakaini tsuite” 検閲の密から日本映画界につ いて, Shineiga 新映画, 1941 (8).

Hiroshima Keizai Daigaku keizai kenkyuron 30(1-2), 日本レコード産業の生成期の牽引車 =日本蓄音器商会の特質と役割 Nippon recodo sangyo no seisenki no keninsha = nipponchikuonki shokai no tokushitsu to yakuwari, October 2007.

Ho Wai-Chung, Popular Music, Cultural Politics and Music Education in China, Routledge, 2016.

Hoadley, Steven and Jürgen Rüland, Asian security reassessed, Institute of Southeast Asian Studies, University of California, 2006.

Honda, Katsuichi, The Nanjing Massacre: A Japanese Journalist Confronts Japan's National Shame, M.E. Sharpe, 1999.

Huang Chun-chieh 黄俊杰, “The Political Thought of Mencius and its Methodological Basis” 孟子的王道政治論及方法論預設), Historical Inquiry, National University of Taiwan History Journal, 16(1991.8).

Huang Min 黃敏, “Minguo shiqi de fuzhuang yanjiu”民國時期的服裝研究, Suzhou daxue shehuixueyuan 蘇州大學社會學院, Zhuzhou gaodeng zhuankexuexiao xuebao 株洲示範高 等專科學校學報 10(4), 2005.

Igarashi Yoshikuni, Bodies of Memory: Narratives of War in Postwar Japanese Culture 19451970, Princeton, NJ: Princeton University Press, 2000.

Inuhiko Yomota, Nihon joyu 日本女優, Tokyo: Iwanami Shoten, 2000.

Japan's Road to War: A Brief Synopsis. Retrieved from URL:

http://www.willamette.edu/ rloftus/rdtowar.html.

Japanese Government Announcement, August 1, 1940, Contemporary Japan, vol IX, no 9, September 1940. 
Jing-Wei, Wang, Advancing Together, 1 January 1940.

Kawamura, Satofumi, “The National Polity and the Formation of the Modern National Subject in Japan,” Japan Forum 2, January 2014.

Kokuritsu kokkai toshokan 国立国会図書館, Rekishi teki ongen 歴史的音原, “Ryukouka: Soshu Yakyoku” “流行歌：蘇州夜曲.” Retrieved from URL:

http://rekion.dl.ndl.go.jp/info:ndljp/pid/3572952.

Komuin soumucho kouhousho “Manshukoku denei seisaku oyoubikishinkashi” 国務院総務 庁弘報処「満洲国電影政策及び其進化史」，Gusen 弘宣， Issue 31 (1938).

Kono, Kimberley T., “Imperialising Motherhood: The Education of a 'Manchu Girl’ in Colonial Manchuria,” in Michele Mason and Helen Lee (eds), Reading Colonial Japan: Text, Context and Critique, Stanford University Press, 2012.

Kono, Kimberley T., Romance, Family and Nation in Japanese Colonial Literature, Springer 2010.

Ku, Charlotte, Abolition of China's Unequal Treaties and the Search for Regional Stability in Asia, 1919 - 1943, 12 Chinese (Taiwan) Y.B Int’l L. \& Aff. 67, 1994.

Lary, Diana, Chinese Migrations: The Movement of People, Goods and Ideas over Four Millenia. Rowman \& Littlefield Publishers, 2012.

League of Nations Official Journal Special Supplement no 101/1, 87, “The Resolution of 24 February 1933.”

Lee, Edwin B, “Nichiren and Nationalism,” Monumenta Nipponica 30(1) (Spring 1975).

Liddle, Joanne and Sachiko Nakajimo, “The Defeat of the ilitarist Project,” Rising Suns, Rising Daughters: Gender, Class and Power in Japan. Zen Books, 2000.

Manshu eiga 満州映画, April issue (1), 1940.

Koizumi, Kikue, Manshujin no shojo 満洲人の少女, Shinkyo: Gekkan Manshusha, 1938.

Masahiko, Amakasu 甘粕正彦, “Manjin no tameni eiga wo tsukuru” 満人のために映画を作 
る, Eiga Shunpo 映画旬報, 1 August 1942 .

Masayasu Hosaka 保阪正康, Taiheiyou sensou wo kangaeru pointo 太平洋戦争を考えるヒ ント, PHP kenkyousho, 2014.

Mathias, Regine, Review of “Reading Colonial Japan: Text, Context and Critique”, Journal of Asian History 47(2), Harrassowitz Verlag, 2013, pp 263-266.

Matsumura, Kazuo, Alone among women: A Comparative Mythic Analysis of the Development of Amaterasu Theology, Institute for Japanese Culture and Classics, Kokugakuin University, 2000. Retrieved from URL: http://www2.kokugakuin.ac.jp/ijcc/wp/cpjr/kami/matsumura.html.

McClain, James L, Japan: A Modern History. W.W. Norton Company, 2002.

McKercher, B.J.C., "National Security and Imperial Defence: British Grand Strategy and Appeasement, 1930-1939,” Diplomacy \& Statecraft 19(3), 2008.

Michael K. Bourdaghs, “Japan’s Orient in Song and Dance,” in Sino-Japanese Transculturation: From the Late Nineteenth Century to the End of the Pacific War, Lexington Books, 2012.

“Minstrel show”, Encyclopaedia Britannica. Retrieved from URL: https://www.britannica.com/art/minstrel-show.

Miwa Kimitada, "Pan-Asianism in modern Japan - Nationalism, regionalism and universalism,” in Sven Saaler and J. Victor Koschmann (eds), Pan-asianism in Modern Japanese History Colonialism, Regionalism and Borders, Routledge, 2007.

Mizue art magazine みづ怘, “Zatankai: Kokubou to kokka to bijitsu - Gakka wa naniwo nasubekika” 座談会: 国防国家と美術一画家は何をなすべきか [Forum: National defence, nation and art - What Shall Artists Do?] Bijitsu Shuppansha 美術出版社 1941(1).

Murakami, Haruki, Jay Rubin (trans.), The Wind-Up Bird Chronicle. Random House, 2011.

Nagayama, Chikako, “The Continental Melody - Soldiers and Japan’s Imperial Screen,” in Germán Gil-Curiel (ed), Film Music in 'Minor' National Cinema, Bloomsbury Publishing USA, 2016. 
Nagayama, Chikako, Fantasy of Empire: Ri Koran, subject positioning, and the cinematic construction of space. PhD Thesis, University of Toronto, 2009.

Nihon shoki maki daisan 日本書紀巻第三（神武天皇即位前紀己未年三月丁卯条の「

令」) .

Nippon bungaku denshi toshokan 日本文学電子図書館, Kokutai no Hongi 国体の本義. Retrieved from URL: http://www.j-texts.com/showa/kokutaiah.html.

Nippon no Gunka, "Patriotic March.” Retrieved from URL: http://gunka.sakura.ne.jp/en/aikokukoshinkyoku.htm.

Nitta Hitoshi 新田均, “Arahito gami” “Kokka shindo” to iu gensou - “zetaikami” wo yobidashita no dareka「現人神」「国家神道」という幻想一「絶対神」を呼び出した のは誰か， Jinja shinposha, 2014/15.

Ooba Sayaka, Manshueigakai no yakuwari to sono eikyo 満州映画協会の役割とその影響, Chapter 2 “Manei no yakuwari” 満映の役割, CineMagaziNet! 5 (2001), Kyoto University. Retrieved from URL: http://www.cmn.hs.h.kyoto-u.ac.jp/CMN5/ooba2.html\#chapter2.

Orbaugh, Sharalyn, “Gender, Family and Sexualities,” in Joshua S Mostow (ed), The Columbia Companion to Modern East Asian Literature, Columbia University Press, 2003.

Orbaugh, Sharon, Propaganda Performed: Kamishibai in Japan's Fifteen Year War, BRILL, 2014.

Peng-Nian, Shen 沈鵬年, “Nianqing de qidai - Liu Xue-An de 'He Ri Jun Za Lai’” 年青的期 待 - 劉雪庵的 “何日君再來.” Xingyunliushui jiwang (xia) 行雲流水記往, Shanghai sanlian chubanshe, 2011.

Pike, Francis, Hirohito’s War: The Pacific War, 1941 - 1945, Bloomsbury Publishing, 2016.

Pope, Edgar W., Songs of the Empire: Continental Asia in Japanese Wartime Popular Music, Ann Arbor, Michigan: University of Michigan Press, 2003.

Raleigh, Donald J. Experiencing Russia's Civil War - Politics, Society and Revolutionary 
Culture in Saratov, 1917-1922, Princeton University Press, 2002.

\section{Rissho Ankoku Ron 立正安国論.}

Retrieved from URL: http://www.sokanet.jp/kaiin/gosho_search/page.php?n=26.

Sanseido daichirin 三省堂大辞林 $3^{\text {rd }}$ edition 第三版。

Retrieved from URL:

https://kotobank.jp/word/\%E7\%8E\%8B\%E9\%81\%93\%E6\%A5\%BD\%E5\%9C\%9F-449219.

Sato, Hirou and Ruben Habito, “Nichiren’s View of Nation and Religion,” Japanese Journal of Religious Studies 26(3/4) (Fall 1999).

Sato, Hirou, “Nichiren Thought in Modern Japan: Two Perspectives,” The Journal of Oriental Studies 10(2000).

Shanhaijin 山海經，“Dahuang dongjing” (大荒東經). Retrieved from URL: http://ctext.org/dictionary.pl?if=gb\&id=84169.

Shillony, Ben-ami, Politics and Culture in Wartime Japan. Clarendon Press, 1991.

Shinajihen Rikugun Sakusen (3) Showa 16 nen 12 gatsumade 支那事变陸軍作戦（3）昭和 十六年十二月まで, Asakumo shinbunsha, 1975.

Slaymaker, D., "Shanghai three ways - The 1930s view from Tokyo, Paris and Shanghai," Foreigners and Foreign Institutions in Republican China. Routledge, 2013.

SMG Shanghai TV Official Channel 上海電視臺官方頻道, Documentary of life and death the 1937 Battle of Songhu 生死地- 1937 淞滬抗戰實錄.

Sokka Gakkai 創価学会, Nichiren Buddhism Library, “On Establishing the Correct Teaching for the Peace of the Land." Retrieved from URL: http://www.nichirenlibrary.org/en/wnd1/Content/2. 
Sokka Gakkai 創価学会, “Rissho Ankoku Ron” no teishutsu to hounan「立正安国論」の提 出と法難, Nichiren daishonin no buppou 日蓮大聖人の仏法.

Sun Wen 孙文, Zhong Hua Min Guo Lin Shi Dai Zong Tong Xuan Yan Shu 中华民国临时 大总统宣言书, 1 January 1912. Dr Sun Yat-sen Memorial Hall, Sun Yat-sen Database, Collected Works of Sun Yat-sen Full Text Retrieval System. Retrieved from URL: http://sunology.culture.tw/cgi-

bin/gs32/s1gsweb.cgi?o=dcorpus\&s=id=\%22DS0000000452\%22.\&searchmode=basic.

Tairiku shinpou 大陸新報, 25 April 1940.

Taiwan Yanyi - Chuanqi Geji Li Xianglan 台灣演義 - 傳奇歌姬 李香蘭, 5 October 2014.

Tohmatsu, Haruo and H.P. Wilmott, A Gathering Darkness: The Coming of War to the Far East and the Pacific, 1921-1942, Rowman \& Littlefield Publishers, 2004.

Tanaka Chigaku 田中智学, Shumon no Ishin 宗門の維新, Shishio Bunko 獅子王文庫, 1901.

Tanaka Hiroshi, Utsumi Aiko, and Onuma Yasuaki, "Looking back on my days as Ri Koran,” The Asia-Pacific Journal 2(10), Oct 11 2004. Retrieved from URL: http://apjjf.org/-OnumaYasuaki--Utsumi-Aiko--Tanaka-Hiroshi/1571/article.pdf.

Tanaka, Yuki and Marilyn B. Young, Bombing Civilians: A Twentieth Century History, The New Press, 2010.

The Cabinet Papers, China and Japan. Retrieved from URL: http://www.nationalarchives.gov.uk/cabinetpapers/themes/china-japan.htm.

The China Weekly Review, 29 March 1941.

Theodore de Bary, William (ed), Sources of Japanese Tradition: From earliest times to 1600, vol 2 ( $2^{\text {nd }}$ ed.), Columbia University Press, 2005.

Theodore De Bary, William (ed), Sources of East Asian Tradition: The modern period, Columbia 
University Press, 2008.

Tokyo Gazette 2(2), 1939, "Statement by the Prime Minister Prince Fumimaro Konoe.” Retrieved from HeinOnline, Law Journal Library.

Tsunoda, Fusako 角田房子, Amakasu Taii 甘粕大尉.

Retrieved from URL: http://ktymtskz.my.coocan.jp/cabinet/amakasu.htm\#6.

Tsunoda, Jun 角田堯淳, Kokudo jobutsu 国土成仏. Retrieved from URL: http://www.nichirenaomori.net/houwa/h2808_kakutagyoujun/index.html.

Ueda, Kenichi 上田賢一, Shanghai Boogie Woogie 1945 Hattori Ryoichi no bouken 上海ブ ギウギ 1945 服部良一の冒， Ongaku no tomosha kan, 2003.

Uno, Kathleen, Passages to Modernity: Motherhood, Childhood, and Social Reform in Early Twentieth Century Japan, University of Hawaii Press, 1999.

Waida, Manabu, “Sacred Kingship in Early Japan: A Historical Introduction,” History of Religions 15(4) (May 1976), p. 323.

Wang Xiao Lin 王小林, Nichu hikaku shinwagaku 日中比較神話学, Kyukoshoin 汲古書院, January 2014.

Wakabayashi, Bob T (ed), Modern Japanese Thought. Cambridge University Press, 1998.

Wang, Yiman, “Affective Politics and the Legend of Yamaguchi Yoshiko/Li Xianglan” in Richard King, Katsuhiko Endo and Cody Poulton (eds), Sino-Japanese Transculturation: Late Nineteenth Century to the End of The Pacific War, Rowman \& Littlefield, 2011.

Wang, Yiman, “Screening Asia: Passing, performative translation, and recognition,” Positions 15(2), 2007.

Webster, Torsten, “Nanjing’s Greater Asianism: Wang Jingwei and Zhou Huaren, 1940” in Sven Saaler and Christopher W.A.Szpilman (eds), Pan-Asianism: A Documentary History, 1920 Present, Rowman \& Littlefield Publishers, 2011.

Wright, Quincy (ed), Legal Problems in the Far Eastern Conflict, New York: Institute of Pacific 
Relations, 1941.

Wu, Yong-Mei and Lee Pui-Tak, Graphic Images and Consumer Culture: Analysis of Modern Advertising Culture in China 圖像與商業文化: 分析中国近代廣告, Hong Kong University Press, 2014.

Yamaguchi, Yoshiko 山口淑子 and Fujiwara Sukuya 藤原作, Ri Koran - My half a lifetime 李 香蘭 私の半生, Shinchosha, 1987.

Yamaguchi, Yoshiko, Chen Peng-Ren (trans.) 山口淑子(著)，陳鵬仁(譯)，Li Xianglan Zijuan: Zanzheng, Heping Yu Ge 李香蘭自傳：戰爭、和平與歌，Taipei: Taiwan Shang Wu Ying Shu Guan, 2005.

Yamaguchi, Yoshiko, Ri Koran wo ikite: watashi no rekishisho “李香蘭” 生きて: 私の履 歴書. Nippon Keizai Shinbunsha, 2007.

Yamaguchi Yoshiko and Fujiwara Sakuyu, Chia-ning Chang (trans), Fragrant Orchid - The Story of My Early Life, University of Hawai’i Press, 2015.

Ye Ming, Sun Tao and Ren Peng 葉明, 孫濤, 任鵬, Zhongguo meixue tongshi 中國美學通 史 Jiangsu renmin chubanshe, 2017.

Yoshida, Yutaka 吉田裕, Nihon no guntai: Heishitachi no kindai shi 日本の軍隊一兵士た ち の近代史, Tokyo: Iwami Shoten, 2002.

Yoshimi, Yoshiaki, Grassroots Facism: The War Experience of the Japanese People, Columbia University Press, 2015.

Zhang, Ai-Min (ed) 張愛民(編), “Huagong juzi fangyexian” 化工巨子方液仙, Shangjie wangshi 商界往事, Qinghua daxue chubanshe, 2012.

Zhang, Chen-Jie 張成覺, 1957 Chinese music 1957 中國音樂, China Independent Writers Publishing Inc, 2014.

Zhang, Shuang Di 張雙棣, Huai Nan Zi Xiao Shi (Zeng ding ben)淮南子校釋（增訂 本). Beijing Daxue chubanshe, 2013. 
Zhao Ming-Zhong 趙銘忠 (ed.), Wangweizhengfu xingzhengyuan huiyilu/zhongguo dier lishidangagguan bian 汪偽政府行政院會議録 / 中國第二歴史档案館編, Dangan chubanshe 档案出版社, 1992.

Zhong Guo Zhe Xue Shu Dian Zi Hua Ji Hua 中國哲學書電子化計劃.

Zhongguo sixiangshi cankaoziliaoji: Xianqin zhi weijinnanbeichao juan 中國思想史參考資 料集: 先秦至魏晉南北朝卷 Qinghua daxue chubanshe youxiangongsi, 2005.

Zhu, Pingchao, Wartime Culture in Guilin, 1938 - 1944: A city at war, Lexington Books, 2015. 
